ARIANE DO CARMO LINS CARVALHO

\title{
Variabilidade genética de Vírus Respiratório Sincicial Humano em amostras do grupo B com inserção de 60 nucleotídeos, colhidas em crianças atendidas no Hospital Universitário na cidade de São Paulo
}

Dissertação apresentada ao Programa de Pós-Graduação Interunidades em Biotecnologia USP/Butantan/IPT, para obtenção do Título de Mestre em Biotecnologia.

São Paulo

2008 
ARIANE DO CARMO LINS CARVALHO

\title{
Variabilidade genética de Vírus Respiratório Sincicial Humano em amostras do grupo B com inserção de 60 nucleotídeos, colhidas em crianças atendidas no Hospital Universitário na cidade de São Paulo
}

\author{
Dissertação apresentada ao \\ Programa de Pós-Graduação Interunidades \\ em Biotecnologia USP/Butantan/IPT, para \\ obtenção do Título de Mestre em \\ Biotecnologia. \\ Área de Concentração: Biotecnologia \\ Orientador: Prof. Dr. Edison Luiz Durigon
}

São Paulo

2008 
DADOS DE CATALOGAÇÃO NA PUBLICAÇÃO (CIP)

Serviço de Biblioteca e Informação Biomédica do

Instituto de Ciências Biomédicas da Universidade de São Paulo

reprodução não autorizada pelo autor

Carvalho, Ariane do Carmo Lins.

Variabilidade genética de vírus respiratório sincicial humano em amostras do grupo B com inserção de 60 nucleotídeos, colhidas em crianças atendidas no Hospital Universitário na cidade de São Paulo / Ariane do Carmo Lins Carvalho. -- São Paulo, 2007.

Orientador: Edison Luiz Durigon.

Dissertação (Mestrado) - Universidade de São Paulo. Instituto de Ciências Biomédicas. Programa de Pós-Graduação Interunidades em Biotecnologia EP/IPT/ICB/Butantan. Área de concentração:

Biotecnologia. Linha de pesquisa: Variabilidade genética de vírus respiratório sincicial humano.

Versão do título para o inglês: Genetic variability human respiratory syncytial virus in group B 60-nucleotide-duplication samples from children admitted in University Hospital in São Paulo city.

Descritores: 1. Vírus respiratório sincicial humano 2. Glicoproteína $G$ 3. Variabilidade genética 4. Análise filogenética 5 . Região G2 I. Durigon, Edison Luiz II. Universidade de São Paulo. Instituto de Ciências Biomédicas. Programa de Pós-Graduação em Biotecnologia. III. Título. 
Candidato(a):

Título da Dissertação:

Orientador(a):
Ariane do Carmo Lins Carvalho.

Variabilidade genética de vírus respiratório sincicial humano em amostras do grupo B com inserção de 60 nucleotídeos, colhidas em crianças atendidas no Hospital Universitário na cidade de São Paulo.

Edison Luiz Durigon.

A Comissão Julgadora dos trabalhos de Defesa da Dissertação de Mestrado, em sessão pública realizada a .....................................
( ) Aprovado(a)
( ) Reprovado(a)

Examinador

(a): Assinatura:

Nome:

Instituição:

Examinador(a):

Assinatura:

Nome:

Instituição:

Presidente:

Assinatura:

Nome:

Instituição: 


\section{PARECER 806/CEP}

Prezada Senhora

Atendendo sua solicitação, a Comissão de Ética em Pesquisas com Seres Humanos do ICB, em sua $78^{\circ}$ reunião realizada em 12.09.07, analisou o projeto de sua responsabilidade intitulado: "Variabilidade genética de RSV B, genótipo BAlike, de amostras colhidas em crianças atendidas no Hospital Universitário na cidade de São Paulo em 2006".

informo a V.Sa. que, após análise e discussão, o referido projeto foi aprovado por esta Comissāo.

Lembramos que cabe ao pesquisador elaborar e apresentar a este Comitê, relatórios anuais (parciais ou final), de acordo com a resolução $196 / 06$ do Conselho Nacional da Saúde, item $1 \times .2$ letra $c$.

O primeiro relatório deverá ser encaminhado à Secretaria deste CEP em 12 de setembro de 2008.

Atenciosamente,

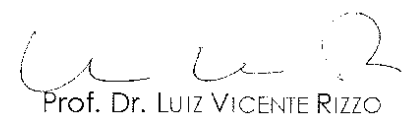

Coordenador da Comissão de Ética em

Pesquisas com Seres Humanos - ICB/USP

IIma. Sra.

Ariane do Carmo Lins Carvalho

Biotecnologia

Instituto de Ciências Biomédicas -USP

Comissão de Ética em Pesquisa com Seres Humanos do Instituto de Ciências Biomédicas / USP Aprovada pela Comissão Nacional de Ética em Pesquisa - CONEP, em 10 de fevereiro de 1998 
Ao pequeno Matheus, pela grande alegria . 


\section{AGRADECIMENTOS}

A Deus, sobre todas as coisas.

Aos meus pais, pelo carinho e dedicação. Meu amor por vocês é incondicional. Ao Prof. Dr. Edison Luiz Durigon, pessoa de carisma e inteligência admiráveis. À Profa Dra. Viviane Fongaro Botosso, por toda ajuda e pelas palavras de incentivo.

À minha irmã pela ajuda na rotina de vírus respiratório e por ser tão sensata e amiga.

À minha avó Cida e minha tia Marlene, a quem muito devo.

À minha tia Aglais, pela ajuda do início ao fim. Obrigada por se importar tanto com alguém que sempre pareceu tão distante.

Aos Drs. César Dinóla e Maria Luisa Barbosa, pelas palavras (e broncas) e por não me deixarem desistir.

Ao Prof. Dr. Manoel Armando Azevedo dos Santos e a Jacinta, por terem cuidado da parte burocrática.

À Profa. Dra. Charlotte Mariana Harsi e todo pessoal de seu laboratório.

Aos meus grandes amigos, Luciano, Miguel e Carolzinha, por tornarem esses anos de minha vida tão divertidos.

À Angélica e Cláudia, por dispensarem seu precioso tempo para me ajudar. Às meninas da rotina 2006 (ex-Metagirls): Teca, Dani Bruna, Andréa, Maria Paula e novamente à Larissa. Vocês foram sensacionais!

Ao Dr. Saulo Duarte Passos, pelo meu início no mundo da pesquisa.

$\grave{A}$ todas as pessoas do laboratório, que direta ou indiretamente fizeram parte desse trabalho: Hildener, Patrícia, Juliana, Lílian, Lilia, Leila, Fábio, Flávia, Hildenir, Dyana, Jansen, Tatiana, Felipe, Claudionor, Adélia, César Filho, Silvana Favoretto e todos os novos ingressantes.

Ao Eduardo, por ter me recebido com um sorriso inesquecível, há 5 anos atrás. Aos amigos Maria Cristina e Milton Scramin. 
Ao Ismael, por entender meus choros, por ser tão dedicado e por dividir comigo esse amor.

À Danila, por ter sido minha psicóloga em tempo integral, durante a realização desse trabalho.

Aos funcionários da Secretária de Biotecnologia, sempre tão dispostos a ajudar.

À Fabiana Silveira, por ter perdido horas de sono, ajudando-me no início do Mestrado.

Às minhas amigas da Odontologia: Cristiane, Giuliane, Vanessa, Eliana, Janaína, Juliana e Jeane.

À Larissa Bergheme, diretora do Laboratório De Análises Clínicas do Hospital Brigadeiro, pela compreensão pelas muitas vezes em que precisei me ausentar do Laboratório.

Às crianças do Hospital Universitário, sem suas preciosas participações, nada disso seria possivel. 
"Embora ninguém possa voltar atrás e fazer um novo começo, qualquer um pode começar agora $e$ fazer um novo fim".

Francisco Cândido Xavier 


\section{RESUMO}

Carvalho ACL. Variabilidade genética de Vírus Respiratório Sincicial Humano em amostras do grupo B com inserção de 60 nucleotídeos, colhidas em crianças atendidas no Hospital Universitário na cidade de São Paulo [Dissertação]. São Paulo: Instituto de Ciências Biomédicas da Universidade de São Paulo; 2008.

O Vírus Respiratório Sincicial Humano (HRSV) é o principal agente viral causador de doença respiratória em bebês e crianças em idade pré-escolar. A fim de estudar a variabilidade genética de HRSV, grupo B, com inserção de 60 nucleotídeos no gene G, selecionamos amostras de aspirado de nasofaringe de crianças menores de 5 anos de idade, com doença respiratória aguda, admitidas no Hospital Universitário da Universidade de São Paulo. Testamos 521 amostras, das quais $35,3 \%$ foram positivas para HRSV. A região G2 da glicoproteína G foi utilizada para genotipar essas amostras. Todas as amostras do grupo B apresentaram a inserção de 60 nucleotídeos no gene da proteína G, como descrito anteriormente em Buenos Aires, em 1999. As modificações de aminoácidos e nucleotídeos dessas amostras foram comparadas com outras amostras com inserção de 2001-2005. A seqüência de nucleotídeos duplicados foi a cópia exata dos 60 nucleotídeos precedentes em vírus mais antigos, mas as cópias do segmento duplicado acumularam substituições de nucleotídeos em vírus mais recentes.

Palavras-chave: Vírus Respiratório Sincicial Humano; Glicoproteína G; Variabilidade genética; Análise Filogenética; Região G2, Inserção de 60 nucleotídeos. 


\begin{abstract}
Carvalho ACL. Human Respiratory Syncytial Virus genetic variability in group B 60-nucleotideduplication samples from children admitted in University Hospital in São Paulo city [Master Thesis]. São Paulo: Instituto de Ciências Biomédicas da Universidade de São Paulo; 2008.

Human Respiratory Syncytial Virus (HRSV) is the leading viral cause of respiratory illness in infants and young children. In order to study the genetic variability of HRSV group B, with 60nucleotide duplication in the gene G, we selected nasopharyngeal aspirates samples of children less than five years of age, with acute respiratory illness admitted in the University Hospital of São Paulo (USP). We tested 521 samples and the HRSV-detection test positivity rate was $35.3 \%$. The G2 region of glycoprotein G was used as genotyping default. All type B HRSV had a 60nucleotide duplication in the attachment protein gene like previously described in Buenos Aires, in 1999. Changes in aminoacids and nucleotides in these samples were compaired with other samples with duplication from 2001-2005. The duplicated nucleotide sequence was an exact copy of the preceding 60 nucleotides in early viruses, but copies of the duplicated segment accumulated nucleotide substituions in more recent viruses.
\end{abstract}

Keywords: Human Respiratory Syncytial Virus; G Glycoprotein; Genetic Variability; Phylogenetic Analysis; G2 Region; 60-nucleotide duplication. 


\section{LISTA DE ILUSTRAÇÕES}

Figura 1 - Modelo representativo do Vírus Respiratório Sincicial Humano

Figura 2 - Esquematização do genoma do HRSV, mostrando sua ordem gênica

Figura 3 - Esquema representativo dos domínios conservados e variáveis da

glicoproteína $\mathrm{G}$

Figura 4 - Análise das seqüências isoladas em Buenos Aires, 1999

Figura 5 - Esquema do genoma viral, emparelhamento dos primers 50

Figura 6 - Análise filogenética do hRSV grupo A. $\quad 55$

Figura 7 - Análise filogenética do hRSV grupo B com inserção. 56 


\section{LISTA DE TABELAS}

Tabela 1 - Características dos genes do HRSV e seus produtos 23

Tabela 2 - Características dos primer utilizados para o diagnóstico de HRSV 48

Tabela 3 - Características dos primer utilizados para o sequenciamento parcial da 49 proteína G de HRSV

Tabela 4 - Distribuição do HRSV durante seis anos consecutivos (2001-2006), no Hospital Universitário da Universidade de São Paulo, São Paulo, Brasil.

Tabela 5 - Distribuição genotípica das amostras do grupo A durante seis estações

(2001-2006) em São Paulo, Brasil

Tabela 6 - Distribuição genotípica das amostras do grupo B, nos anos de 2001-2006, São Paulo, Brasil. 


\section{LISTA DE ABREVIATURAS E SIGLAS}

\begin{tabular}{|c|c|}
\hline bRSV & RSV bovino \\
\hline CCA & Chimpanzee Coryza Agent \\
\hline cDNA & DNA complementar \\
\hline $\mathrm{CG}$ & Complexo de Golgi \\
\hline DEPC & Dietilpirocarbonato \\
\hline dNTP & Desoxinucleotídeo Trifosfato \\
\hline DRA & Doença Respiratória Aguda \\
\hline EDTA & Ácido Etilenodiaminotetracético \\
\hline ELISA & Ensaio Imunoenzimático \\
\hline HeLa-I & Células derivadas de carcinoma cervical \\
\hline HEp-2 & Células de carcinoma de laringe humana \\
\hline HMPV & Metapneumovírus humano \\
\hline HRSV & Vírus Respiratório Sincicial Humano \\
\hline HU-USP & Hospital Universitário da Universidade de São Paulo \\
\hline IF & Imuno fluorescência \\
\hline $\operatorname{Ig}$ & Imunoglobulina \\
\hline IL & Interleucina \\
\hline $\mathrm{KDa}$ & quilodalton \\
\hline MAb & Anticorpo Monoclonal \\
\hline $\mathrm{mL}$ & mililitro \\
\hline MPV & Vírus da Pneumonia do Camundongo \\
\hline mRNA & Ácido Ribonucléico Mensageiro \\
\hline NCI-H292 & Células de carcinoma mucoepidermóide de pulmão humano \\
\hline ng & Nanograma $\left(10^{-9}\right.$ grama $)$ \\
\hline $\mathrm{nm}$ & Nanômetro (10-9 metro) \\
\hline ORF & Janela de Leitura Aberta \\
\hline $\mathrm{pb}$ & Pares de Base \\
\hline PCR & Reação em Cadeia pela Polimerase \\
\hline $\mathrm{pH}$ & Potencial hidrogeniônico \\
\hline PIV & Vírus da Parainfluenza \\
\hline PM & Peso Molecular \\
\hline RNA & Ácido Ribonucléico \\
\hline RNAi & Ácido Ribonucléico de Interferência \\
\hline RNAse & Ribonuclease \\
\hline RNP & Ribonucleoproteína \\
\hline rpm & Rotações por minuto \\
\hline RT-PCR & PCR por Transcrição Reversa \\
\hline ssRNA & RNA de fita simples \\
\hline TBE & Tampão TRIS-Borato-EDTA \\
\hline TNF alpha & Fator de Necrose Tumoral Alfa \\
\hline TRI & Trato Respiratório Inferior \\
\hline TRIS & Tris (hidroximetil) aminometano \\
\hline $\mathrm{U}$ & Unidade \\
\hline UTI & Unidade de Terapia Intensiva \\
\hline UV & Radiação Ultravioleta \\
\hline $\mathrm{V}$ & Volts \\
\hline
\end{tabular}


Vero

$\mu \mathrm{g}$

$\mu \mathrm{L}$

Células de rim de macaco

microgramas

microlitros 


\section{LISTA DE SÍMBOLOS}

\section{BASES NITROGENADAS DOS}

\section{NUCLEOTÍDEOS}

Adenina

A

Citosina

C

Guanina

Timina

G

Uracila

\section{AMINOÁCIDOS}

Ácido Aspártico

D

Ácido Glutâmico

E

Alanina

A

Arginina

$\mathrm{R}$

Asparagina

$\mathrm{N}$

Cisteína

C

Fenilalanina

F

Glicina

G

Glutamina

Q

Histidina

$\mathrm{H}$

Isoleucina

I

Leucina

L

Lisina

K

Metionina

M

Prolina

$\mathrm{P}$

Serina

$\mathrm{S}$

Tirosina

Y

Treonina

$\mathrm{T}$

Triptofano

W

Valina 


\section{SUMÁRIO}

1 INTRODUÇÃO 19

$\begin{array}{llr}1.1 & \text { Histórico } & 19\end{array}$

$\begin{array}{lll}1.2 & \text { Características do vírus } & 20\end{array}$

$\begin{array}{ll}\text { 1.2.1 Classificação } & 20\end{array}$

$\begin{array}{ll}\text { 1.2.2 Estrutura do vírus } & 21\end{array}$

1.2.3 Estrutura do Genoma 22

1.2.4 Proteínas Virais $\quad 24$

1.2.5 Replicação e transcrição do genoma viral 29

1.2.6 Características do crescimento em cultura celular $\quad 30$

$\begin{array}{ll}\text { 1.2.7 Caracterização antigênica } & 31\end{array}$

1.2.8 Amostras do grupo B com inserção de 60 nucleotídeos 32

$\begin{array}{lll}1.3 & \text { Aspectos clínicos } & 33\end{array}$

1.4 Diagnóstico Laboratorial 36

$\begin{array}{lll}1.5 & \text { Epidemiologia } & 39\end{array}$

1.6 Vacinas contra o HRSV 42

$\begin{array}{lll}1.7 & \text { Tratamento } & 43\end{array}$

2 OBJETIVOS 45

3 MATERIAL E MÉTODO $\quad 46$

$\begin{array}{lll}3.1 & \text { Casuística } & 46\end{array}$

3.2 Diagnóstico do HRSV 46

3.2.1 Colheita das amostras $\quad 46$

3.2.2 Processamento das amostras 46

$\begin{array}{lll}3.3 & \text { RT-PCR } & 47\end{array}$

3.3.1 Extração do RNA total $\quad 47$

3.3.2 Obtenção do DNA complementar (cDNA) 47

3.3.3 Primers utilizados no diagnóstico do HRSV 47

3.3.4 PCR diagnóstico para HRSV 48

3.3.5 Detecção dos produtos amplificados (GeneScan) 48 
3.4 Amplificação da seqüência parcial do gene codificador da proteína $\mathbf{G}$

3.5 Análise dos produtos amplificados 50

3.6 Precipitação e purificação do produto amplificado 50

3.7 Seqüenciamento parcial do gene G do HRSV 51

3.8 Processamento e alinhamento das seqüiências do gene G do HRSV 52

3.9 Análises genealógicas $\quad 52$

4 RESULTADOS $\quad 54$

5 DISCUSSÃO $\quad 60$

6 CONCLUSÕES $\quad 64$

REFERÊNCIAS BIBLIOGRÁFICAS

$\begin{array}{lr}\text { ANEXOS } & 80\end{array}$ 


\section{INTRODUÇÃO}

\subsection{Histórico}

O Vírus Respiratório Sincicial Humano (HRSV) é reconhecido como o agente viral mais freqüentemente relacionado a casos de bronquiolite e pneumonia durante a infância e idade pré-escolar. Cerca de $95 \%$ das crianças têm a primeira infecção pelo HRSV nos primeiros dois anos de vida, sendo que o pico de incidência ocorre nos primeiros meses de vida (Anderson et al., 1990). Em aproximadamente 40\% das crianças há o desenvolvimento de sintomas envolvendo o trato respiratório inferior durante a primeira infecção (Hall et al., 1991). Os casos de reinfecção pelo HRSV são comuns durante toda a vida, mesmo em indivíduos com altos níveis de anticorpos, porém os sintomas clínicos em crianças com idade mais avançada e em adultos são de natureza mais branda (Hall et al., 1991).

Em 1955, no Walter Reed Army Institute of Research, Washington DC, Estados Unidos, Morris e colaboradores (1956) isolaram, pela primeira vez, o HRSV a partir de swab de garganta de chimpanzés que apresentavam sinais clínicos comuns às doenças respiratórias: coriza, secreção nasal purulenta, tosse e espirro. $O$ isolamento foi realizado em cultura de células hepáticas e inoculado em animais de laboratório: camundongos, ratos, cobaios, hamsters, coelhos e chimpanzés; porém somente os primatas desenvolveram os sinais da doença (Chanock et al., 1957a). O agente isolado passou a chamar-se Chimpanzee Coryza Agent (CCA) (Morris et al., 1956).

Em 1957, um vírus semelhante foi isolado em Baltimore em duas crianças, uma apresentando pneumonia e outra laringotraqueobronquite. O nome CCA foi, portanto, substituído por Human Respiratory Syncytial Vírus (HRSV), para designar sua origem humana, sua afinidade pelo trato respiratório e sua capacidade de produção de sincícios em cultura celular (Chanock et al., 1957a; Chanock et al., 1957b).

Estudos sorológicos posteriores mostraram que a maior parte das crianças de Baltimore já havia sido infectada pelo HRSV antes dos quatro anos de idade. Outros estudos, realizados em diversas regiões do mundo, apontaram o HRSV como agente associado a doenças no trato respiratório inferior (TRI), bronquiolite e pneumonia, sendo mais tarde reconhecido como principal patógeno de doenças do TRI em crianças e também associado a grupos de imunocomprometidos, pessoas com doenças 
cardiopulmonares, idosos e transplantados (Chanock et al., 1957b; Collins et al., 2001; Falsey e Walsh, 2000).

No Brasil, o vírus foi isolado pela primeira vez por Candeias em 1964, em quatro crianças hospitalizadas com quadro respiratório agudo. A confirmação do isolamento em cultura celular foi feita através da prova de neutralização com soro padrão (Candeias, 1967).

\subsection{Características do vírus}

\subsubsection{Classificação}

O HRSV pertence à ordem Mononegavirales, à qual fazem parte os vírus formados por RNA de fita simples e polaridade negativa; família Paramyxoviridae, subfamília Pneumovirinae e gênero Pneumovirus. A partícula do HRSV não apresenta as proteínas de superfície Hemaglutinina e Neuraminidase e sua classificação é baseada na morfologia da partícula (van Regenmortel et al., 2000).

As características da família Paramyxoviridae, segundo Collins e colaboradores (2001) são:

- Genoma constituído por fita única de RNA sentido negativo, associado às proteínas virais, formando um nucleocapsídeo helicoidal, resistente à ação de RNAses;

- Transcrição do genoma de forma seqüencial e dependente da polimerase viral;

- A replicação viral ocorre no citoplasma da célula hospedeira;

- Vírions envelopados, sendo o envelope adquirido da membrana plasmática da célula hospedeira;

- A penetração do vírus na célula hospedeira ocorre por fusão de membranas, com utilização de uma proteína de fusão do envelope viral.

Na família Paramyxoviridae, além da subfamília Pneumovirinae (à qual o HRSV pertence), encontra-se a subfamília Paramyxovirinae, na qual estão incluídos os Vírus Sendai, Vírus do Sarampo, Vírus da Caxumba, Vírus da Parainfluenza Humano, entre outros (van Regenmortel et al., 2000).

Pertencem ao gênero Pneumovírus, além do HRSV, o RSV bovino (bRSV) e o Vírus da Pneumonia do Camundongo (Murine Pneumonia Vírus - MPV) (van Regenmortel et al., 2000). 
Em 2001, van den Hoogen e colaboradores identificaram um novo membro da família Paramyxoviridae: o Metapneumovírus Humano (HMPV), que foi classificado na subfamília Pneumovirinae e gênero Metapneumovirus. Esse vírus provoca sinais clínicos muito semelhantes aos causados pelo HRSV. O HMPV apresenta RNA sentido negativo e partículas envelopadas com um diâmetro aproximado de $200 \mathrm{~nm}$. Ao contrário do HRSV, o HMPV não apresenta os genes que codificam as proteínas não estruturais (NS1 e NS2). Todos os outros genes estão presentes no HMPV, porém em posições diferentes das observadas no HRSV.

\section{HMPV: 3' - N - P - M - F - M2 -SH - G - L - 5'}

$$
\text { HRSV: } 3^{\prime}-\text { NS1 - NS2 - N - P - M - SH- G - F - M2 - L - 5' }
$$

\subsubsection{Estrutura do vírus}

O HRSV é um vírus pleomórfico, cuja estrutura final é envelopada e apresenta de 150 a $300 \mathrm{~nm}$. O vírion é composto de um nucleocapsídeo envelopado de simetria helicoidal e diâmetro variando de 12 a $15 \mathrm{~nm}$. O envelope viral consiste na dupla camada lipídica originária da membrana citoplasmática da célula hospedeira. $\mathrm{Na}$ superfície do envelope são encontradas glicoproteínas de origem viral, que estão envolvidas no processo de adesão e penetração. Essas espículas formam projeções de 11 a $20 \mathrm{~nm}$ e estão separadas umas das outras por intervalos de 6 a $10 \mathrm{~nm}$ (Collins et al., 2001; Huang e Wertz, 1982;) (Figura 1).

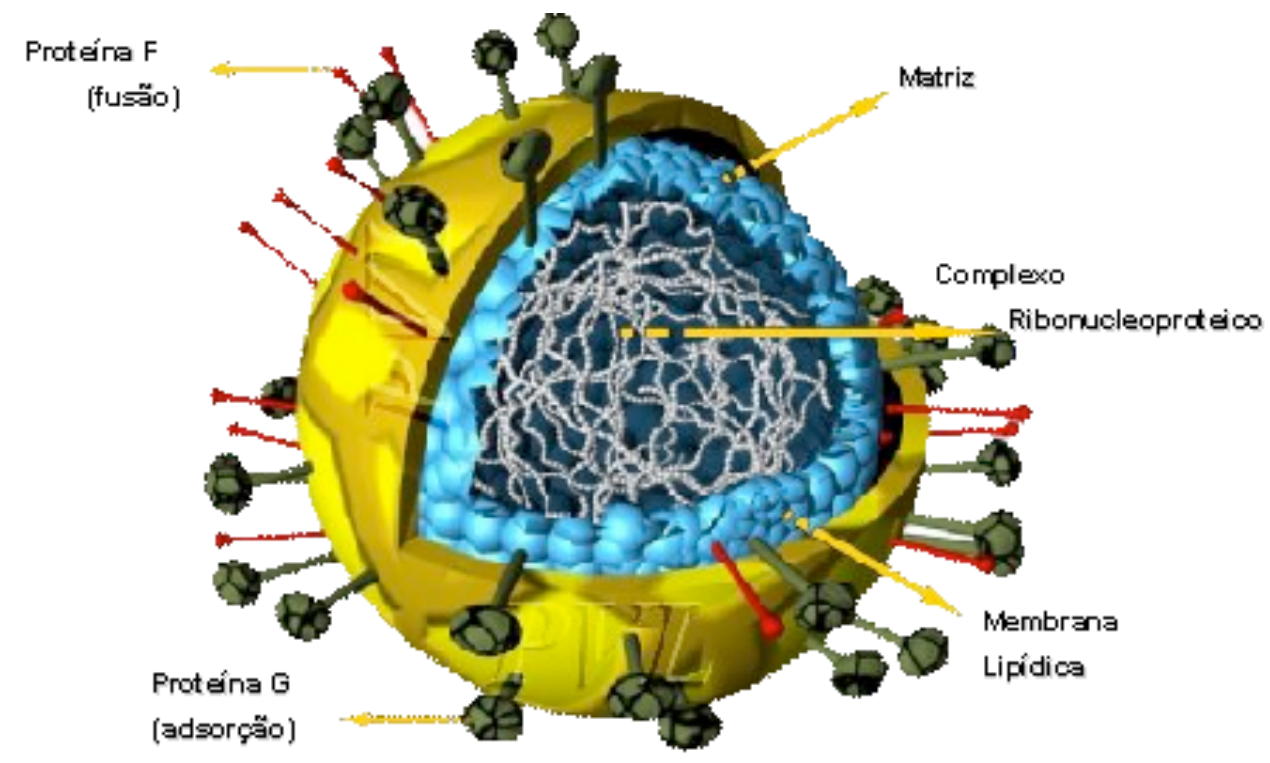

Figura1- Modelo representativo do Vírus Respiratório Sincicial Humano. Modificado de "The Big Picture Book of Viruses", acessado em 07/01/2008 e disponível em http://www.tulane.edu/ dmsander/Big_Virology/BVHomePage.html 
Cada partícula contém apenas uma cópia funcional do genoma (Collins et al., 2001). O peso molecular de seu genoma é de aproximadamente $5 \times 10^{3} \mathrm{kDa}$ e contém cerca de 15.222 nucleotídeos (Collins et al., 2001; Welliver, 2003). O genoma é composto de RNA de fita simples não segmentado, de polaridade negativa (-ssRNA). Devido a não segmentação, esse vírus não possui a mesma capacidade de rearranjos entre os segmentos genômicos, como ocorre com o Vírus Influenza. Contudo, podem ocorrer mutações, assim como em outros vírus de RNA (Collins et al., 2001).

\subsubsection{Estrutura do Genoma}

Nas células infectadas pelo HRSV são identificadas 11 proteínas (Tabela 1). O vírus apresenta três glicoproteínas de superfície: G (adesão), F (fusão) e SH (small hydrophobic). As proteínas F e G glicosiladas estão presentes na superfície do envelope viral e são importantes imunógenos durante a infecção viral. A proteína $F$ é relativamente conservada em relação à proteína G (Collins et al., 2001; Sullender et al., 1998).

Logo abaixo do envelope, há uma camada de revestimento formada pela proteína M (matriz) viral. Na parte interna da partícula viral encontra-se o nucleocapsídeo, constituído por quatro proteínas que formam um complexo com o RNA genômico: N (nucleoproteína), P (fosfoproteína), M2-1 e L(Large - polimerase); além de proteínas que não entram na constituição do vírion: NS1 (proteína não estrutural 1), NS2 (proteína não estrutural 2), e M2-2. A NS1 e a NS2 estão presentes em abundância nas células infectadas, mas em pequena quantidade nos vírions (Collins et al., 2001).

O HRSV possui 10 RNAs mensageiros (mRNA) subgenômicos. Cada um possui uma ORF (Open Reading Frame), exceto o M2, que possui duas, que codificam as proteínas M2-1 e M2-2 (Collins et al., 2001).

Na porção 3' do RNA genômico, há uma região extragênica de 44 nucleotídeos (região leader). A região leader é seguida por dez genes virais, que obedecem a seguinte ordem: 3' - NS1 - NS2 - N-P-M - SH- G - F - M2 - L - 5' (Figura 2, Tabela 1).

O gene L é seguido de uma região extragênica de 155 nucleotídeos, conhecida como região trailer, que é mais tolerante a inserção ou deleção de nucleotídeos que a região leader. Os genes começam com um sinal conservado de início do gene, 
composto por nove nucleotídeos (3'- CCCCGUUUA), exceto o gene L cuja seqüência apresenta as seguintes diferenças: (CCCUGUUUUA). O término de cada gene ocorre com um sinal semi conservado que direciona a terminação transcripcional e a poliadenilação (Collins et al., 2001).

Os nove primeiros genes são separados por regiões intergênicas que variam de 1 a 56 nucleotídeos. Essas regiões são pouco conservadas entre amostras. Os dois últimos genes fazem uma sobreposição (overlap) de 68 nucleotídeos, assim sendo o gene L tem o início de sua transcrição dentro do gene M2 e o sinal de término e poliadenilação do gene M2 está localizado dentro do gene L (Collins et al., 2001).

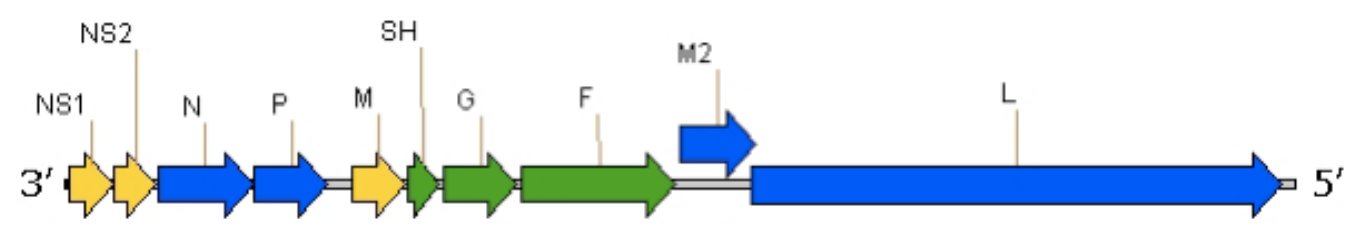

Figura 2 - Esquematização do genoma do HRSV, mostrando sua ordem gênica. Em azul estão os genes que codificam proteínas constituintes do nucleocapsídeo e em verde estão destacados os genes das glicoproteínas de superfície. O gene M2 possui duas ORFs: M2-1 e M2-2 (Carromeu, 2007).

Tabela 1 - Características dos genes do HRSV e seus produtos

\begin{tabular}{ccccc}
\hline Gene & $\begin{array}{c}\text { Tamanho do gene } \\
\text { (nucleotídeos) }\end{array}$ & $\begin{array}{c}\text { Tamanho da } \\
\text { proteína } \\
\text { (aminoácidos) }\end{array}$ & $\begin{array}{c}\text { Peso da proteína } \\
\text { não processada } \\
\text { (KDa) }\end{array}$ & $\begin{array}{c}\text { Peso da proteína } \\
\text { processada (KDa) }\end{array}$ \\
\hline N & 1203 & 391 & 43 & 45 \\
P & 914 & 241 & 27 & 33 \\
L & 6578 & 2165 & 250 & 250 \\
M2-1 & 961 & 194 & 22 & 22 \\
F & 1903 & 574 & 63 & 70 \\
G* & 923 & 298 & 33 & 90 \\
SH & 410 & 64 & 8 & 8 \\
M & 958 & 256 & 29 & 25 \\
NS1 & 532 & 139 & 16 & 14 \\
NS2 & 503 & 124 & 15 & 15 \\
M2-2 & 961 & 90 & 11 & 11 \\
\hline
\end{tabular}

Legenda do agrupamento por cores:

- rosa: constituintes do nucleocapsídeo;

- verde: glicoproteínas de superfície;

- laranja: proteína de matriz;

- azul: proteínas não estruturais
Modificado de Carromeu, 2007

* Há divergências na literatura quanto ao tamanho do gene e da proteína produzida, pois esses dados podem variar de 292 a 319 aminoácidos, de acordo com a amostra viral (Trento et al., 2006). 


\subsubsection{Proteínas Virais}

As proteínas NS1 (PM 15,5 KDa) e NS2 (PM 14,6 KDa) possuem, respectivamente, 139 e 124 aminoácidos. Suas funções não estão bem elucidadas, mas parecem estar relacionadas à regulação da síntese de RNA, morfogênese do vírion ou à interação com células hospedeiras (Collins et al., 2001). Estudos "in vitro" demonstraram que NS1 possui forte poder inibitório da transcrição e replicação do RNA, mas ainda não se estabeleceu o quanto essa regulação negativa é importante na infecção natural (Atreya et al., 1998).

O nucleocapsídeo presente nas partículas virais maduras do HRSV é formado pelo RNA genômico complexado com as proteínas N, P, L e M2-1 (Collins et al. 2001).

A associação entre as proteínas N, P e L com o RNA viral já é suficiente para que o complexo apresente uma atividade de replicase (Collins et al., 1996; Yu et al., 1995). No entanto, a proteína M2-1 é necessária para uma eficiente transcrição do genoma pela polimerase viral (Fearns e Collins, 1999; Hardy e Wertz, 1998).

A proteína $\mathrm{N}$ possui 391 aminoácidos e $\mathrm{PM}$ de $43,4 \mathrm{KDa}$, está associada ao RNA genômico e é a principal proteína estrutural do nucleocapsídeo (Collins et al., 2001). O RNA genômico e anti-genômico do HRSV encontra-se sempre complexado com a proteína $\mathrm{N}$ e este complexo é usado como molde para a síntese de RNA. Este complexo proteína N-RNA tem diversos benefícios para o vírus, prevenindo a formação de estruturas secundárias na molécula de RNA, protegendo a mesma de degradação por nucleases e reduzindo a formação de RNAs dupla-fita, poderia levar a uma reposta celular antiviral (Cowton et al., 2006).

A proteína P possui 241 aminoácidos e PM de aproximadamente $35 \mathrm{KDa}$. É uma proteína altamente fosforilada, ácida e que desempenha função importante no processo de transcrição e replicação do HRSV (Collins et al., 2001). A proteína P constitui uma subunidade da polimerase viral (formada pelas proteínas P e L) e, por analogia com outros vírus pertencentes à ordem Mononegavírus, parece mediar o contato entre a proteína L e o complexo proteína N-RNA (Tran et al., 2007).

A proteína L, a maior proteína do HRSV, é constituída de 2165 aminoácidos e PM de $250 \mathrm{KDa}$. Esta proteína contém seis segmentos altamente conservados e com possíveis domínios funcionais. Esta é a proteína estrutural de menor abundância na partícula viral (Collins et al., 2001). Atribui-se a essa proteína as atividades enzimáticas 
de RNA-polimerase-RNA-dependente, além de poliadenilação e formação de estrutura de cap do mRNA viral (Barik, 1992; Barik, 1993; Mason et al., 2004).

A proteína M2-1 (PM $22 \mathrm{KDa})$ possui 194 aminoácidos. Essa proteína é interna e não glicosilada e interage com as proteínas $\mathrm{N}$ e $\mathrm{P}$, atuando no processo de transcrição, evitando seu término prematuro (Collins et al., 2001), além de favorecer a passagem da polimerase viral pela região intergênica, facilitando o acesso dessa polimerase à unidade final da transcrição (Hardy et al., 1998). Essa proteína tem função na replicação do HRSV e alterações em sua seqüência podem diminuir a infectividade do vírus (Tang et al., 2001).

A proteína M2-2 possui 90 aminoácidos, $\mathrm{PM}$ de $11 \mathrm{KDa}$ e está relacionada à regulação da transcrição e replicação do RNA viral (Atreya et al., 1998). A M2-2, quando expressa em altos níveis, inibe completamente a replicação do HRSV, sugerindo que essa proteína, quando produzida nas células infectadas em grande quantidade, pode ser um fator crítico na replicação do HRSV (Cheng et al., 2005).

Células infectadas pelo HRSV apresentam inclusões citoplasmáticas bem definidas. Essas inclusões contêm a proteína $\mathrm{N}$, as polimerases virais (proteínas $\mathrm{P}$ e L) (Collins et al., 1996) e a proteína de fator de elongação transcripcional M2-1 (Garcia et al., 1993). Garcia-Barreno e colaboradores (1996) sugerem que essas inclusões sejam ribonucleoproteína (RNP) agregada.

A proteína M (PM $27 \mathrm{KDa}$ ) possui 256 aminoácidos, é uma proteína interna e não glicosilada. Essa proteína está associada ao nucleocapsídeo do HRSV nas células infectadas e no vírion e, como as proteínas de matriz de outros vírus de RNA fita negativa, pode inibir a transcrição viral (Ghildyal et al., 2002). A associação da proteína M com o nucleocapsídeo facilita a montagem do vírus (Lenard et al., 1996).

A glicoproteína de superfície SH é uma molécula pequena, com apenas 64 aminoácidos e PM $8 \mathrm{KDa}$. A SH é uma proteína transmembrana, que se insere na membrana citoplasmática da célula hospedeira através um uma seqüência hidrofóbica. Em células infectadas pelo HRSV, essa proteína pode apresentar-se de quatro formas diferentes, dependendo do peso molecular e da glicosilação. Dentre formas, duas não são glicosiladas SH0 (7,5 KDa) e SHt (4,5 KDa); SHg (com 13-15 KDa), é a forma Nglicosilada da SH0 e a SHp (21-40 KDa) é modificada da SHg pela adição de uma polilactosaminoglicana (Collins et al., 1993; Collins et al., 2001). A função da SH ainda 
não está completamente elucidada, mas possivelmente sua atuação esteja relacionada ao Complexo de Golgi (CG) da célula hospedeira, no qual a $\mathrm{SH}$ modificaria suas propriedades, a fim de facilitar o transporte das proteínas virais pela via de secreção, uma vez que, apesar de estar presente em todo citoplasma da célula hospedeira, essa proteína acumula-se nas estruturas da membrana do CG (Rixon et al., 2004).

Fuentes e colaboradores (2007) demonstraram que a proteína SH do HRSV tem função semelhante à SH do vírus da Parainfluenza 5 (PIV 5), no qual está associado com a inibição da sinalização do fator de necrose tumoral alfa (TNF-alpha), que está associado, entre outras funções, com a sinalização para apoptose de células infectadas por vírus.

A proteína F possui 574 aminoácidos, PM de $70 \mathrm{KDa}$. É uma glicoproteína de fusão, sendo a responsável pela ligação do envelope viral com a membrana citoplasmática da célula hospedeira, fazendo com que o nucleocapsídeo seja liberado no interior do citoplasma (Walsh e Hruska, 1983). Essa proteína também proporciona a fusão da célula infectada com a célula adjacente, para a formação de sincícios (Collins et al., 2001).

As espículas da proteína $\mathrm{F}$ apresentam-se sob forma homotetramérica, na qual cada espícula é formada por quatro unidades iguais da proteína e são responsáveis por induzir a formação de anticorpos neutralizantes (Sullender et al., 1998).

Low e colaboradores (2008), em um estudo sobre a interação das proteínas F, G e $\mathrm{SH}$, sugeriram que as proteínas $\mathrm{F}$ e $\mathrm{G}$ formam um complexo na superfície das células infectadas pelo HRSV, porém não encontraram nenhuma evidência de que as três proteínas juntas formem um complexo. Apesar dos mecanismos que levam a fusão de membrana em células infectadas pelo HRSV ainda não serem bem entendidos, as associações entre as proteínas $\mathrm{G}$ e F encontradas nesse estudo, sugerem que a proteína G tem papel indireto no processo de fusão.

A proteína $\mathrm{G}$ possui de 289 a 319 aminoácidos, dependendo da amostra viral. Em oposição a $\mathrm{F}$, essa proteína não é conservada e pode ser homomérica ou homotetramérica (Collins et al., 2001). O gene que codifica a proteína G possui, em geral, 918 nucleotídeos no grupo A e entre 920 a 980 nucleotídeos no grupo B (Johnson et al., 1987; Trento et al., 2003). Essa proteína é sintetizada com $33 \mathrm{KDa}$, sendo glicosilada posteriormente para obtenção da forma madura, com $90 \mathrm{KDa}$. 
Em 1987, Levine e colaboradores demonstraram, em coelhos, que a glicoproteína $\mathrm{G}$ possui função de adsorção, pois os anticorpos contra essa proteína inibiram a ligação do vírus às células hospedeiras. A proteína $G$ é análoga a hemaglutinina de outros vírus da família Paramyxoviridae, porém sem apresentar ação hemaglutinante (Sullender et al., 1998).

Mutações espontâneas, que conduzem a deleção dos genes SH e G (Karron et $a l ., 1997)$ e vírus, fabricados pela engenharia genética, com remoção do gene G inteiro foram isolados em cultura celular (Techaarpornkul et al., 2001). Esses vírus podem replicar-se com eficiência em alguns tipos celulares, como as células Vero, porém não o fazem em outros, como as células HEp-2. Quando inoculados em camundongos BALB/ c, esses vírus apresentam-se atenuados (Teng et al., 2001). Assim sendo, parece que a proteína $\mathrm{G}$, embora não seja necessária para infecção de certos tipos celulares, é requerida para que o vírus apresente infectividade eficiente, podendo ser essa a razão para sua presença em todos os vírus isolados até o momento (Melero et al., 1997).

A proteína G é uma glicoproteína tipo II (ou seja, está ancorada à membrana próxima à sua porção amino-terminal por um domínio hidrofóbico, não clivável, tipo sinal âncora, que se estende do resíduo 38 ao 66), que não apresenta seqüência, nem características estruturais semelhantes às outras proteínas de adesão de outros Paramyxovirus (Lichtenstein et al., 1996; Wertz et al., 1985). Essa proteína é produzida de duas formas na célula infectada: uma forma ligada à membrana (Gm), de 292 a 319 aminoácidos (dependendo da amostra viral), que é incorporada ao vírion; E na forma solúvel (Gs), que é secretada das células infectadas. A Gs permanece monomérica, enquanto que a Gm forma oligômeros, principalmente tetrâmeros (Escribano-Romero et al., 2004).

O ectodomínio carboxila-terminal da glicoproteína G possui alto teor de serina e treonina, sendo possíveis sítios de ligação de glicídios por ligações glicosiladas do tipo “O” (o glicídio liga-se a átomos de oxigênio das cadeias desses aminoácidos). A ligação também pode ser do tipo "N" (ligação entre glicídio e átomo de nitrogênio da cadeia lateral da asparagina). O ectodomínio externo contém mais de 70 sítios potenciais para adição de oligossacarídeos por ligações glicosídicas tipo “O”, porém a proteína madura possui apenas 24 ou 25 cadeias de glicídios O-ligados. O ectodomínio externo apresenta também 3 a 8 sítios para adição de oligonucleotídeos para ligação glicosídica tipo 
"N" (Johnson et al., 1987; Wertz et al., 1995). A proteína G apresenta também alto teor de resíduos de prolina, que contribuem para minimizar as estruturas secundárias da proteína (Collins et al., 2001).

Em 1991, Canes e colaboradores determinaram a seqüência nucleotídica do gene codificante para a proteína de adesão $(\mathrm{G})$ de algumas amostras de HRSV e verificaram 80 a 99\% de variabilidade de aminoácidos entre elas. Determinou-se que essa variabilidade não se apresentava randomicamente distribuída pela seqüência e sim em um domínio hipervariável separado de outro domínio variável (esse mais extenso) por uma região de alta conservação. Esses fatos sugerem que a pressão imunológica, em certas áreas da proteína $\mathrm{G}$, poderia estar relacionada à habilidade do vírus reinfectar $\mathrm{o}$ indivíduo por diversas vezes. $\mathrm{O}$ grande interesse na proteína $\mathrm{G}$ reside no fato dessa ser a proteína com maior variabilidade nos isolados virais, podendo suportar inserções, deleções e substituições de aminoácidos, sem com isso perder a funcionalidade (Anderson et al., 1985; Johnson et al., 1987, Trento et al., 2003). Em alguns vírus, as mutações podem determinar a mudança do códon de terminação, alterando o tamanho da proteína G codificada por esse gene (Martinez et al., 1999; Sullender et al., 1991).

A variabilidade genética da proteína $G$ vem sendo estudada e mecanismos de escape do HRSV, apoiados nessa variabilidade, vêm sendo elucidados (Arbiza et al., 2005; Galiano et al., 2005; Sullender et al., 1993; Zlateva et al., 2005). Essas regiões variáveis encontram-se entre os aminoácidos 69-164 e 207-298, podendo ser observada divergência de 53\% entre amostras dos grupos A e B (Johnson et al., 1987).

A região que compreende o aminoácido 164 até o 176 e os quatro resíduos de cisteína $\left(\mathrm{C}^{173}, \mathrm{C}^{176}, \mathrm{C}^{182}\right.$ e $\left.\mathrm{C}^{186}\right)$ é conservada em todas as amostras de HRSV, sugerindo que esse fragmento seja o responsável pela ligação do vírus a um receptor na célula hospedeira (Figura 3) (Sullender, 2000). 


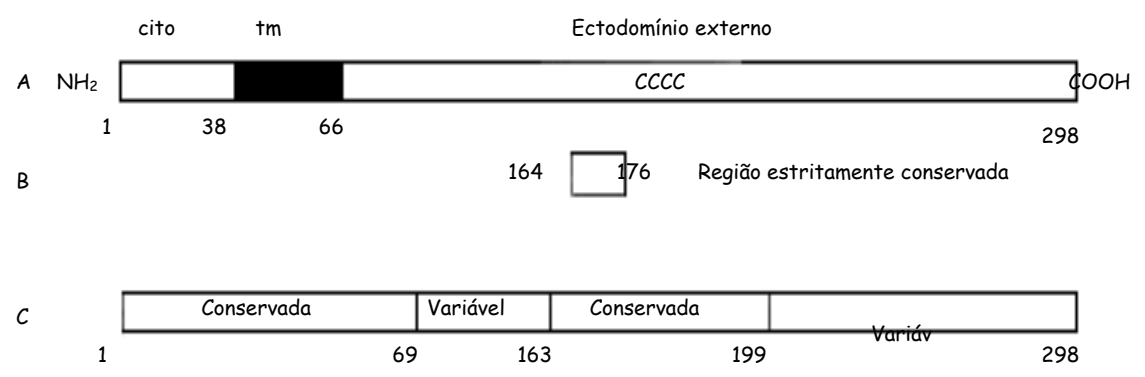

Figura 3 - Esquema representativo dos domínios conservados e variáveis da glicoproteína G.

(A) Estrutura primária dos aminoácidos da proteína $\mathrm{G}$, de isolado A2, sendo: cito = domínio interno a membrana citoplasmática; $\mathrm{tm}$ = domínio transmembrana; CCCC quatro resíduos de cisteína $\left(C^{173}, C^{176}, C^{182}\right.$ e $\left.C^{186}\right)$ conservados em todas amostras. (B) Região com 13 aminoácidos, estritamente conservada nas amostras de HRSV; (C) Regiões variáveis da proteína G intra e intergrupos do HRSV, ricas em serina e treonina e as regiões conservadas. As regiões transmembrana e citoplasmática, que compreendem os aminoácidos 1-69, são conservadas. Modificado de Sullender, 2000.

As proteínas de superfície $\mathrm{F}$ e $\mathrm{G}$ são as mais importantes para a resposta imune, sendo que anticorpos monoclonais (MAbs) ou policlonais específicos contra elas, são capazes de neutralizar o vírus in vitro (Anderson et al., 1988; Hendry et al., 1988).

\subsubsection{Replicação e transcrição do genoma viral}

A adsorção do vírus a receptores presentes na superfície da célula epiteliais do trato respiratório do hospedeiro é mediada pela glicoproteína G. Após a fusão do envelope com a membrana plasmática (que é mediada pela proteína F), o nucleocapsídeo é liberado no citoplasma, onde serve como molde para transcrição e replicação. Todas as etapas ocorrem no citoplasma sem o envolvimento do núcleo celular (Collins et al., 2001).

A transcrição é iniciada em um único promotor localizado em uma região 3' não codificante do genoma denominada leader (na qual a enzima RNA polimerase RNAdependente faz contato, iniciando a transcrição do primeiro nucleotídeo), acontecendo de maneira seqüencial, terminando e reiniciando a cada gene do HRSV. Diferentemente do RNA genômico, os mRNAs gerados são poliadenilados na extremidade 3' e apresentam a estrutura de cap na extremidade 5' (Cowton et al., 2006; Fearns et al., 2002).

Na junção entre a região leader e o primeiro gene, o transcrito é liberado e a polimerase recomeça a transcrição por um mecanismo seqüencial de início-fim, sendo guiada pelos sinais de início e de fim do gene, resultando na síntese de uma série de 
mRNAs subgenômicos. Algumas vezes, a polimerase não reconhece estes sinais, o que gera a criação de um gradiente de expressão (Collins et al., 1984; Collins e Wertz, 1983; Dickens et al., 1984), sendo que os genes mais próximos do promotor são expressos em maior quantidade que os mais distais. Um nucleocapsídeo pode conter cem vezes mais proteína $\mathrm{N}$ em sua estrutura do que proteína L (Collins et al., 2001).

Após alguns ciclos de transcrição e tradução dos mRNAs gerados, aumenta o nível de proteínas virais que irão formar o nucleocapsídeo no citoplasma. Com isso, através de um processo que ainda não é bem conhecido, a polimerase viral começa um ciclo de replicação do genoma, com a geração de antigenomas e genomas, ambos complexados com a proteína $\mathrm{N}$ (Cowton et al., 2006).

A replicação do genoma produz moldes adicionais para replicação e transcrição e fornece grande quantidade de genoma para ser incorporado às novas partículas virais. A produção da fita complementar de RNA positivo (+ssRNA), que irá servir de molde para geração de cópias do genoma viral de RNA negativo (-ssRNA) requer que o aparato envolvido na produção do RNA não reconheça sinais de início e fim presente entre os genes e entre a seqüência leader e o gene N1 (Kingsbury, 1990).

A maturação viral ocorre com a montagem do nucleocapsídeo, através da combinação do RNA genômico com a proteína $\mathrm{N}$, que é acompanhado em seguida pela adição das proteínas P e L. Para a montagem do envelope, as proteínas de superfície sofrem glicosilação quando passam pelo retículo endoplasmático e Complexo de Golgi. Essas proteínas ocupam lugar das proteínas celulares, na membrana plasmática. As proteínas de matriz agregam-se na porção interna do envelope em formação. $O$ nucleocapsídeo chega à superfície e é liberado por brotamento, levando uma porção da membrana plasmática, em um processo inverso à penetração por fusão (Kingsbury, 1990).

\subsubsection{Características do crescimento em cultura celular}

O HRSV possui características importantes que tornam sua propagação difícil em cultura celular. Embora esse vírus replique em várias linhagens celulares, incluindo HEp-2, HeLa e células Vero, o efeito citopático típico (o sincício) e os títulos virais variam consideravelmente, dependendo da variante do vírus e das condições das células para cultivo. Altos títulos virais são difíceis de serem obtidos na maioria das variantes 
virais. O HRSV é termolábil e perde rapidamente a infectividade em temperatura ambiente. Assim como outros vírus envelopados, o HRSV é rapidamente degradado pela ação de detergentes (Falsey e Walsh, 2000).

\subsubsection{Caracterização antigênica}

Em 1963, Coates e colaboradores observaram diferenças antigênicas entre duas amostras de HRSV (A2 e Long). Outras diferenças antigênicas foram observadas, em um estudo posterior, entre as amostras virais Long e CH18537 (Coates et al., 1966). Ambos os estudos utilizaram a reação de neutralização com soro de animal hiper-imune (coelhos e cobaios), demonstrando que a amostra A2 não era neutralizada pelo soro preparado com Long ou CH18537, sugerindo a existência de diferentes variantes cocirculando em uma mesma população.

Com o surgimento dos anticorpos monoclonais (MAbs), os isolados virais foram classificados em dois grupos antigênicos por suas reatividades com um painel de MAbs (Anderson et al., 1985; Mufson et al., 1985). Subseqüentemente, estudos genéticos demonstraram que os dois grupos antigênicos correspondem a grupos geneticamente distintos (Cristina et al., 1990). Um estudo da seqüência das cepas padrões de ambos grupos antigênicos indicou que a proteína de adesão $(\mathrm{G})$ do vírus é menos conservada que outros genes (Johnson et al., 1987). Dentro de cada grupo, a proteína G também mostrou alto grau de diversidade antigênica e genética (Arbiza et al., 2005).

Alguns estudos demonstraram que os grupos A e B têm, aproximadamente, 25\% de homologia antigênica, sendo que a proteína $\mathrm{G}$ possui correlação antigênica de apenas 1 a 7\%, o que confere ao vírus um mecanismo de evasão de uma resposta imune préexistente (Johson et al., 1987; Mufson et al., 1985;).

Outros estudos demonstraram a existência de diferenças antigênicas dentro de cada grupo. Inicialmente, foram identificados sete subgrupos do tipo A (A1 a A7) e quatro do tipo B (B1 a B4) (Anderson et al., 1991; Hall et al., 1990). Atualmente, baseado na variabilidade do gene G, classifica-se os genótipos GA1 a GA7 no grupo A (Peret et al., 1998, 2000) e SAA1 (Venter et al., 2001) e o grupo B, nos genótipos GB1 a GB4 e SAB1 a SAB3 (Gilca et al., 2006; Venter et al., 2001).

Desde 1999, vem sendo relatada, em diversas localidades, a circulação de um novo genótipo pertencente ao grupo B e ao genótipo GB3. Esse genótipo caracteriza-se 
por apresentar uma duplicação de 60 nucleotídeos no gene G (Kuroiwa et al., 2005; Nagai et al., 2004; Sato et al., 2005; Scott et al., 2004; Trento et al., 2003; Zlateva et al., 2004, 2005). Outras inserções menores (3 a 6 nucleotídeos) também vêm sendo encontradas, demonstrando a ampla variabilidade da proteína $\mathrm{G}$ de amostras do grupo $\mathrm{B}$ (Blanc et al., 2005).

1.2.8 Amostras do grupo B com inserção de 60 nucleotídeos

Trento et al. (2003) descreveram, em Buenos Aires, três isolados de HRSV (BA3833/99B, BA3859/99B, BA4128/99B, nomeados vírus BA) classificados no grupo antigênico B, que continham uma duplicação de 60 nucleotídeos na região C-terminal do gene da proteína G. Dessas amostras, duas apresentavam iguais seqüências e a outra (BA3859/99B) mostrava duas diferenças (A ${ }^{72}-G$ e $A^{329}-G$, na fita negativa), sendo que apenas a última modificação traduzia para um aminoácido diferente ( $\left.\mathrm{L}^{105}-\mathrm{P}\right)$. Não foram observadas diferenças na taxa de crescimento e na formação de sincício entre os vírus BA e outros isolados de HRSV (Figura 4).
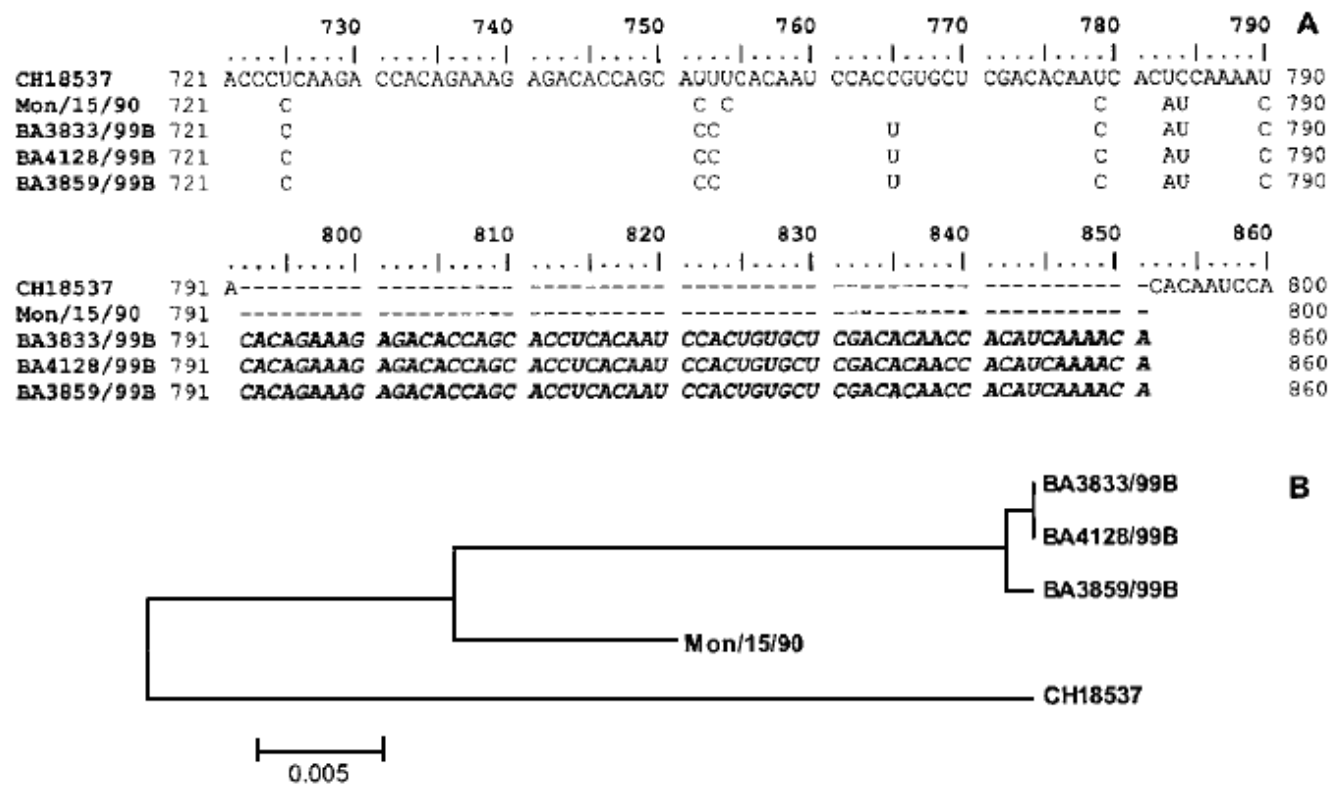

Figura 4 - Análise das seqüências isoladas em Buenos Aires, 1999. (A) Seqüência nucleotídica parcial do gene da proteína G de HRSV (sentido positivo). (B) Análise filogenética dos vírus representados em (A), utilizando as amostras CH18547 (protótipo do grupo antigênico B) e Mon/15/90 para a comparação. Adaptado de Trento et al. (2003).

A seqüência nucleotídica do gene $G$ dos vírus BA é traduzida em um polipeptídeo de 315 aminoácidos. Essa proteína apresenta características estruturais 
iguais às proteínas $\mathrm{G}$ de outros isolados de $\mathrm{HRSV}$, tais como uma região de cisteínas e a presença de múltiplos sítios potenciais para a glicosilação da ligação $\mathrm{O}$ e $\mathrm{N}$ no ectodomínio da proteína (Trento et al., 2003).

Embora sejam comuns os relatos de seqüências de proteína $\mathrm{G}$ com duplicação ou deleção de 1 ou 2 aminoácidos, essas mutações são encontradas esporadicamente e perdidas nos anos seguintes, porém, nenhuma descrição sobre uma duplicação tão longa na proteína $\mathrm{G}$ foi feita até hoje, além do grande período de tempo que essa variante vem circulando (Blanc et al., 2005; Garcia et al., 1994; Melero et al., 1997; Trento et al., 2006; Zlateva et al., 2005).

As vantagens seletivas do HRSV com essa inserção sobre outros genótipos permanecem ainda desconhecidas, mas provavelmente a condição imunológica da população em relação a esse vírus pode ter contribuído para sua disseminação mundial (Trento et al., 2006).

\subsection{Aspectos clínicos}

As doenças agudas do trato respiratório inferior (TRI) constituem importante causa de internação hospitalar de crianças com idade inferior a cinco anos. A maioria das doenças do TRI são infecções brônquicas e alveolares, responsáveis por $90 \%$ das mortes por patologia respiratória em países em desenvolvimento. As infecções de brônquios e bronquíolos são reconhecidas como de etiologia viral em sua maioria e os quadros pneumônicos são freqüentemente associados a agentes bacterianos, sendo pouco reconhecida a participação de agentes virais nesses casos. Já em países em desenvolvimento, os agentes virais são vistos como responsáveis pela maior parte das infecções, tanto de origem brônquica como alveolar (Miyao et al., 1999).

Segundo Thomazelli et al (2007), os principais agentes virais, relatados no Brasil, associados à patogenia dessas infecções das vias aéreas inferiores são, em ordem decrescente de freqüência, o HRSV, Metapneumovírus Humano, Parainfluenza 3, Adenovírus, Influenza A e Parainfluenza 1, porém muito agentes patogênicos permanecem ainda sem identificação.

A transmissão do HRSV pode ocorrer por contato com secreções, via aerossol e objetos contaminados, sendo muito infeccioso quando em contato com mucosas do olho 
ou nasal. A inoculação do vírus na mucosa oral de voluntários demonstrou não ser eficiente (Hall, 1981).

A infecção nosocomial do trato respiratório é um problema relevante para pacientes pediátricos internados e pode agravar as condições clínicas do paciente, prolongando o período de internação e elevando o custo com o tratamento. As infecções nosocomiais mais freqüentes e graves ocorrem em crianças internadas em unidades de terapia intensiva (UTI), berçários e unidades oncológicas, devido a menor competência imunológica desses pacientes e o uso de respiradores, cateteres e nutrição parenteral, reconhecidos como fatores de risco. Funcionários de hospitais também podem contribuir na disseminação do vírus, pela presença de secreção contaminada nas mãos, roupas e outros objetos. Em ambientes fechados, creches e escolas, a propagação do vírus é favorecida. Crianças lactentes infectadas com o HRSV excretam grandes quantidades de partículas virais, facilitando a contaminação de indivíduos próximos (Hall et al., 1975; Vieira et al., 2002).

O número de crianças hospitalizadas em um mesmo quarto e a permanência no hospital são fatores que aumentam a disseminação do vírus (Hall et al., 1975). O índice de infecções hospitalares, durante o surto de HRSV, pode aumentar de 26 para $47 \%$ em berçários e de 20 para 40\% em unidade com crianças mais velhas (Collins et al., 2001).

A replicação do HRSV em células do trato respiratório causa processo inflamatório, que inclui destruição epitelial, edema e aumento na produção de muco. Esse vírus possui um período de incubação médio de 3 a 5 dias, a partir do qual os primeiros sintomas ocorrem. As manifestações clínicas típicas são secreção nasal clara, tosse moderada, febre baixa, sibilância, evoluindo na maioria dos casos para a recuperação do quadro clínico em aproximadamente uma semana, porém, em alguns casos, incluindo pacientes de risco (crianças prematuras, com problemas cardiopulmonares, imunodeficientes, transplantados e com fibrose cística), as manifestações podem evoluir para um quadro mais grave, com pneumonia e bronquiolite, requerendo hospitalização (Ogra 2004; Ruuskanen et al., 1993).

As manifestações clínicas variam de acordo com a idade do paciente, o estado de saúde e se é a primeira infecção por HRSV. Recém-nascidos e crianças geralmente apresentam infecção do trato respiratório inferior (bronquiolite ou pneumonia) (Glezen et al., 1986), entretanto, crianças mais velhas e adultos têm, mais freqüentemente, 
sintomas no trato respiratório superior (Hall et al., 2001) ou traqueobronquite, mas podem também desenvolver sintomas do trato respiratório inferior, particularmente em idosos e imunocomprometidos ( Walsh et al., 1999).

A tosse é um dos sintomas mais comuns e afeta de 90 a $97 \%$ dos pacientes. A febre é observada em aproximadamente $50 \%$ das pessoas com doença respiratória causada pelo HRSV, porém as temperaturas são mais baixas do que as observadas nas infecções pelo Vírus Influenza (Falsey e Walsh, 2000). Podem também ocorrer sintomas como otite média (Nokso-Koivisto et al., 2004), asma e sinusite (Osur, 2002).

As infecções por HRSV associadas à predisposição alérgica, podem comprometer os pulmões e contribuir para o desenvolvimento de doenças inflamatórias, tais como a asma (Becnel et al., 2005).

A apnéia está presente em aproximadamente $20 \%$ das crianças hospitalizadas com HRSV (Anas et al., 1982; Bruhn et al., 1977; Church et al., 1984; Hall et al., 1979). A apnéia ocorre freqüentemente em crianças mais novas, em prematuros e aquelas com hipoxemia mais severa (Bruhn et al., 1977; Church et al., 1984; Hall et al., 1979). Na maioria das crianças reinfectadas com o HRSV, a apnéia não reaparece (Anas et al., 1982; Bruhn et al., 1977; Church et al., 1984).

A imunidade adquirida após a primeira infecção pelo HRSV não é suficiente para prevenir uma nova infecção um ano após a exposição, entretanto, há uma considerável redução na severidade a partir da terceira reinfecção. Infecções recorrentes pelo HRSV podem ocorrer durante toda a vida (Henderson et al., 1979), sendo a alta variabilidade genética do vírus, principalmente da proteína $G$, considerada uma das principais causas das infecções recorrentes (Parveen, 2006).

Arbiza e colaboradores (2005) analisaram a variação genética da proteína $\mathrm{G}$ de HRSV isoladas de crianças imunodeprimidas em episódios consecutivos de doença respiratória e compararam com isolados de HRSV circulantes na população geral. Não foi encontrada modificação nas seqüências de aminoácidos desses isolados, sugerindo infecção clínica permanente ou crônica nas crianças com supressão imunológica, provavelmente devida a insuficiência da resposta imunológica. 


\subsection{Diagnóstico Laboratorial}

O diagnóstico efetivo das infecções respiratórias virais, bem como o reconhecimento e entendimento dos benefícios e limitações dos testes laboratoriais são essenciais para evitar o uso desnecessário de antibióticos e evitar infecções nosocomiais, nas quais o HRSV apresenta-se muito freqüentemente envolvido (Henrickson e Hall, 2007).

O diagnóstico pode ser direto: detecção de antígeno viral, do ácido nucléico ou do vírus infectante, ou pode ser indireto: detecção de anticorpos específicos para o agente (Waris, 1992). Os quatro principais métodos de diagnóstico da infecção por HRSV são cultura, detecção do antígeno por imunofluorescência (IF) ou por imunoensaio enzimático (ELISA), detecção do RNA por Reação em cadeia pela polimerase após a transcrição reversa (RT-PCR) e por sorologia, pela detecção de IgM específico para HRSV ou pelo aumento significante dos anticorpos IgGs (Falsey e Walsh, 2000). A combinação de ensaios moleculares e imunológicos é a abordagem mais sensível para o diagnóstico das infecções virais (Rovida et al., 2005).

Um dos métodos diagnósticos para detecção do HRSV é o isolamento viral em culturas celulares. Nessa técnica, a presença do vírus pode ser observada pelo aparecimento de efeito citopático na cultura, visível a microscópio óptico (Halstead et al., 1990). O efeito citopático pode aparecer em um período de 1 a 15 dias, e a identificação viral é feita por reação com anticorpos ou técnicas moleculares. Atualmente a cultura não é mais tão utilizada para o diagnóstico.

O isolamento em cultura de células pode ser realizado em ampla variedade de células humanas e animais, sendo as mais utilizadas HEp-2 (carcinoma de laringe humana) e NCI-H292 (carcinoma mucoepidermóide de pulmão humano) (Hierholzer et al., 1993; Tristam e Welliver, 1996). Outras linhagens como Vero (rim de macaco) e fibroblastos humanos também são úteis para o isolamento viral, apesar de serem menos sensíveis do que as linhagens epiteliais humanas (Tristam e Welliver, 1996). Perini e colaboradores (2007) demonstraram que HeLa-I é adequada para o isolamento viral, mostrando resultados similares aos alcançados com a utilização de células HEp-2. A utilização de células HEp-2, HeLa-I e NCI-H292 em conjunto, melhora a detecção do HRSV. Outro estudo realizado com diferentes linhagens celulares para isolamento de HRSV mostrou que a combinação de linhagens para o isolamento é mais eficiente do 
que a utilização de apenas um tipo. A sensibilidade obtida ao utilizar 3 linhagens chega a $95 \%$ e com a utilização de duas, a sensibilidade cai para 90\%. Entretanto, esses números só foram obtidos quando as células HEp-2 estão inclusas entre as linhagens (Arens et al., 1986).

A centrifugação da placa de cultura após a inoculação do material clínico pode aumentar a eficiência do isolamento, pois facilita a adsorção do vírus na linhagem celular (Hughes, 1993). Reis (2006) utilizou em seu estudo três metodologias para isolamento do HRSV (cultura em tubos estacionários, roller e placa) e encontrou dados semelhantes quanto à sensibilidade.

Alguns fatores podem interferir na eficácia do isolamento viral, tais como condições de coleta e manuseio das amostras. Por ser termolábil, o HRSV necessita de condições adequadas de transporte, tais como rapidez (deve ser processado entre 1 e 2 horas após a coleta) e refrigeração a $4{ }^{\circ} \mathrm{C}$ durante o transporte (Falsey e Walsh, 2000). A presença de bactérias ou enterovírus na amostra também pode diminuir ou mesmo anular o efeito citopático no isolado viral (Kellogg, 1991).

A técnica de imunofluorescência (IF) é largamente utilizada para detecção do HRSV em células epiteliais da nasofaringe ou para a confirmação do vírus após isolamento em cultura celular. Essa técnica apresenta 80 a $90 \%$ de especificidade e sensibilidade quando comparada à técnica de isolamento, além de oferecer estabilidade das amostras que são fixadas em lâminas (Kellogg, 1991). Por outro lado, essa técnica demanda profissionais bem treinados em microscopia, além da presença de quantidade adequada de células na lâmina. A presença de excesso de muco pode prejudicar a leitura, por ocasionar fluorescência inespecífica. Porém, o muco pode ser removido durante a preparação da lâmina, pela ação de agentes químicos quelantes de muco ou mesmo por ação mecânica (pipetagens repetidas) (Tristam e Welliver, 1996).

O ensaio imunoenzimático (ELISA) é outro método rápido que pode ser utilizado para detecção do HRSV. Esse teste pode ser aplicado para a detecção de antígenos virais presentes na amostra e para identificação viral em isolados de cultura celular. Para a realização desse teste, a presença de células intactas do trato respiratório não é necessária e graças à automação, pode ser realizado em grande número de amostras simultaneamente, além de tratar-se de um teste de leitura mais objetiva (Kellogg, 1991). Esses testes utilizam-se, geralmente, de uma combinação de anticorpos 
monoclonais (MAbs) para a captura de antígenos em fase sólida, seguido da adição de anticorpos antiantígenos, marcados com peroxidase (Chao et al., 1979; Sarkkinen et al., 1981). A desvantagem dessa técnica é que não se apresenta tão sensível quanto a imunofluorescência, podendo apresentar falso-positivos (Abels et al., 2001; Kellogg, 1991).

Ohm-Smith e colaboradores (2004) compararam a eficácia de métodos de diagnóstico rápidos: Binax NOW assay (Binax, Inc., Portland, Maine), BD Directigen EZ assay (Becton Dickinson and Company, Sparks, Md.), BD Directigen RSV assay (DRSV) (Becton Dickinson and Company) e imunofluorescência direta, com a cultura de células para detecção de HRSV em amostras frescas de crianças e adultos. Nenhum dos três kits de diagnóstico rápido foi sensível para o diagnóstico, sendo a melhor escolha para diagnóstico rápido, a imunofluorescência direta.

Métodos de biologia molecular, tais como a RT-PCR, que detecta o ácido nucléico do vírus diretamente da amostra, e hibridização têm sido amplamente utilizados no diagnóstico para HRSV (Causse et al., 2007; Nascimento et al., 2007; Peret et al., 1998 e 2000). A RT-PCR é utilizada no diagnóstico de infecções, principalmente, quando a quantidade e o período de excreção são pequenos, como acontece com pessoas idosas (Ong et al., 2001;).

Vários multiplex PCR e RT-PCR foram desenvolvidos, demonstrando sensibilidade igual ou, mais comumente superior à cultura de células e outros métodos de detecção de antígenos (Rovida et al., 2005; Thomazelli, 2004; Weinberg et al., 2004). Reis (2006) testou amostras clínicas através da pesquisa direta de antígenos de HRSV por imunofluorescência com anticorpos monoclonais, isolamento viral em cultura celular e RT-PCR, encontrando nessa última maior sensibilidade em relação às outras.

Thomazelli (2004) comparou a imunofluorescência com a técnica de GeneScanRT-PCR para o diagnóstico de diversos vírus respiratórios, encontrando boa sensibilidade, especificidade e concordância entre as duas técnicas.

Nascimento (2006) padronizou uma reação em tubo único para o diagnóstico de HRSV em amostras clínicas, a fim de simplificar e reduzir os riscos de contaminação. Amostras foram testadas por imunofluorescência indireta, RT-Nested-PCR e RT-PCR em tubo único. Os resultados obtidos demonstraram que essa técnica é mais rápida, 
sensível e específica, além de ser mais econômica que a IF e com sensibilidade semelhante à RT-Nested PCR.

A Real-Time PCR é uma técnica de diagnóstico baseada na RT-PCR e em uma tecnologia de captação de sinais de fluorescência durante os ciclos da PCR. Van Elden e colaboradores (2003) testaram a Real-Time PCR como teste diagnóstico e concluíram que a RT-Nested-PCR e TaqMan Real-Time-PCR são bem mais sensíveis e rápidos do que a cultura celular para a detecção de HRSV em adultos imunocomprometidos. Outros métodos baseados na técnica de RT-PCR em tempo real têm sido utilizados para a detecção genômica do vírus, tais como SYBR Green e TaqMan (Borg et al., 2003; Dewhurst-Maridor et al., 2004; Hu et al., 2003). A PCR em tempo real diminui a manipulação do produto amplificado (amplicons), evitando contaminações, é reprodutível e pode ser utilizada para quantificar ácido nucléico (Mackay et al., 2002).

\subsection{Epidemiologia}

O HRSV é um dos mais importantes agentes causadores de infecção aguda do trato respiratório em crianças (Hall, 1994). Em 2002, a Organização Mundial de Saúde estimou que 18,3 milhões de pessoas morrem devido a doenças infecciosas, das quais 3,96 milhões morrem de doenças infecciosas respiratórias. Mais de 95\% das mortes causadas por doenças respiratórias estão relacionadas à infecção do trato respiratório inferior (TRI) (WHO, 2004).

Infecções virais no TRI são particularmente sérias em bebês, pois os pulmões ainda estão se adaptando à vida fora do útero. A bronquiolite viral é a causa mais comum de hospitalização de crianças em países desenvolvidos e aproximadamente $70 \%$ dessas hospitalizações são devidas ao HRSV (Henrickson et al., 2004).

Cerca de $95 \%$ das crianças são infectadas pelo HRSV pela primeira vez durante os dois primeiros anos de vida, sendo a maior incidência entre dois e sete meses (Anderson et al., 1990).

Epidemias pelo HRSV são facilmente identificadas na comunidade, pois há um considerável aumento do número de casos de bronquiolite e pneumonia, com conseqüente aumento nas admissões hospitalares. Estudos realizados com crianças com menos de um ano mostraram que um terço dessas crianças infectadas pelo HRSV desenvolveu doença no TRI (Holberg et al., 1991; Shay et al., 1999). 
O HRSV mostrou ser o agente de maior incidência em infecções nosocomiais em crianças menores de 3 meses, submetidas à ventilação mecânica (Diniz et al., 1999).

Estima-se que o HRSV infecte anualmente 64 milhões de indivíduos no mundo, sendo que aproximadamente 160.000 indivíduos venham a óbito (Girard et al, 2005). Na Europa, o HRSV é responsável por 42 a 45\% das admissões hospitalares de crianças menores de 2 anos, com infecção do TRI (Simões et al., 2003).

No Brasil, a doença respiratória aguda (DRA) é responsável por 25 a $50 \%$ das consultas em postos de saúde e cerca de $67 \%$ dos atendimentos de emergência em hospitais (Sütmoller et al., 1995). Estudos de diferentes áreas geográficas revelaram o HRSV como a principal causa de infecção respiratória em crianças (Arruda et al., 1991; Miyao et al., 1999; Nascimento et al., 1991; Tsuchiya et al., 2005; Vieira et al., 2001). Na cidade de São Paulo, o HRSV foi o patógeno viral mais freqüentemente encontrado em crianças hospitalizadas $(41,8 \%)$ com DRA (Vieira et al., 2001). Outros estudos realizados no Brasil mostraram o HRSV como responsável por 17 a 68\% das infecções virais em crianças internadas (Calegari et al., 2005; Moura et al., 2003; Serafino et al., 2004).

Regiões de clima sub-tropical e temperado apresentam sazonalidade nos surtos de HRSV, ocorrendo entre final de outono, todo o inverno e início da primavera. Uma epidemia dura aproximadamente 5 meses, sendo $40 \%$ dos casos registrados nos meses de pico, que representam os meses do meio do surto (inverno) (Collins et al., 2001).

Países com clima temperado apresentam surtos de novembro a abril, com picos em dezembro e janeiro (inverno) (Hendry et al., 1990). Em países de clima mediterrâneo, a incidência está relacionada aos meses de inverno e em países tropicais está relacionado às estações chuvosas (Weber et al., 1998).

Estudos relatam o isolamento do HRSV durante todo o ano em países com clima sub-equatorial. Em Papuá Nova Guiné, o HRSV é observado durante todo ano, com picos nos meses excessivamente chuvosos (março e outubro). No Havaí, os picos também se relacionam com períodos chuvosos (outubro a abril) e também pode ser encontrado durante todo o ano. Na Austrália, o surto estende-se de abril a setembro, com pico em julho (Hierholzer et al., 1994; Reese e Marchette, 1991).

Yusuf e colaboradores (2007) demostraram haver relação positiva entre picos de HRSV e a umidade e relação negativa entre atividade do HRSV e radiação UVB, que 
seria explicada pela inativação do vírus na presença desta radiação ou pela alteração da resistência do hospedeiro. Um estudo realizado por Donaldson (2006) mostrou que o aumento da temperatura global pode ter um impacto na diminuição do período de surto de HRSV.

No Brasil, os surtos ocorrem no final de outono até início da primavera (Nascimento et al., 1991). Em algumas localidades do país, tais como Fortaleza, Salvador e Uberlândia, os surtos iniciam-se em janeiro ou fevereiro e terminam nos meses de julho e agosto (Calegari, et al., 2005; Moura et al., 2006; Serafino et al., 2004). Segundo Vieira e colaboradores (2001), a sazonalidade em São Paulo é bem definida, estendendo-se pelo outono e inverno, com pico em maio e junho, não estando associada com estações chuvosas, coincidindo, entretanto com a época em que são registrados os maiores índices de poluição do ar. Porém, a relação entre a incidência do vírus e a poluição ambiental é questionada na literatura (Avendaño et al., 2003).

Nascimento e colaboradores (1991) fizeram um estudo longitudinal no Rio de Janeiro, que demonstrou alta incidência do HRSV nos casos mais graves de infecção respiratória aguda. A positividade das amostras iniciou no outono, durante 4 anos consecutivos, indicando ocorrência sazonal.

Em um estudo realizado em neonatos com pneumonia intersticial causada por HRSV, $51,4 \%$ dos episódios ocorreram durante o outono e $48,6 \%$ durante o inverno, mostrando realmente haver sazonalidade desse vírus (Diniz et al., 1999).

A gravidade da doença do trato respiratório pode variar a cada surto. Mudanças no grupo e nas variantes circulantes podem contribuir para essa variação da gravidade anual de cada surto (Hall et al., 1990).

O padrão de circulação dos grupos A e B apresenta grande variação de local para local e de ano para ano. Embora o grupo A seja mais freqüentemente isolado do que o grupo $\mathrm{B}$, verifica-se a co-circulação de ambos os grupos e relatos mais escassos de predominância do grupo B (Botosso, 2002; Hendry et al., 1986; Martinez et al., 1999). A grande freqüência de isolados do grupo A pode ser explicada pela maior variação antigênica desse grupo em relação ao B (Coggins et al., 1998).

Segundo Zlateva e colaboradores (2005), os genótipos que surgem no final de um surto tendem a predominar no início do próximo surto. 
No Brasil, Botosso (2002) realizou um estudo com crianças internadas no Hospital Universitário (HU) da Universidade de São Paulo e observou a co-circulação dos dois grupos (A e B) durante os quatro anos de estudo, com predominância do grupo A, assim como outros estudos realizados no Brasil (Cintra et al., 2001; Siqueira et al., 1991).

Diferença de patogenicidade entre os grupos A e B ainda não estão bem elucidadas. Alguns estudos concluíram que o grupo A causa doença mais severa (Gilca et al., 2006; Imaz et al., 2000; Taylor et al., 1989) e outros que o grupo B é o mais patogênico (Hornsleth et al, 1998). Há ainda estudos no qual não foram observadas diferenças de patogenicidade entre os grupos (Cintra et al., 2001; Struck et al., 2004).

Buckingham e colaboradores (2000) não relacionaram patogenicidade com o grupo do vírus isolado, mas encontraram com a quantidade de partícula virais presentes na secreção.

Questiona-se a influência, não apenas do grupo, mas também do genótipo do HRSV sobre a gravidade da doença (Peret et al., 1998). Outros fatores também podem determinar a patogenicidade do vírus, tais como condições hospitalares, condição sócioeconômica e status imunológico (Ogra, 2004; Silvestri et al., 2004).

Reinfecções envolvendo vírus de um mesmo grupo sugerem que as variações antigênicas intragrupo podem ter significado epidemiológico, porém esses dados ainda não estão completamente esclarecidos (Sullender et al., 1998).

\subsection{Vacinas contra o HRSV}

O HRSV possui características que representam um desafio ao desenvolvimento de uma vacina. Uma dessas características é a possibilidade de reinfecção na presença de imunidade pré-existente, podendo acometer bebês com anticorpos adquiridos passivamente da mãe e pessoas imunologicamente competentes (Glezen et al., 1981; Henderson et al., 1979). Reinfecções podem ocorrer por exposições repetidas a isolados de vírus pertencentes ao mesmo grupo, pois a imunização não é completa e dura um pequeno período de tempo (Hall et al., 1991).

Outra característica reside no fato de que a primeira infecção por HRSV ocorre normalmente entre 2 e 7 meses de idade (Glezen et al., 1986), portanto, uma vacina eficaz deve ser capaz de estimular uma boa resposta imune antes dos 2 meses de idade. 
Porém a imaturidade imunológica do indivíduo nessa idade dificulta a produção desse tipo de vacina (Collins et al., 2001). A maioria dos indivíduos que se encontram dentro do grupo de risco para apresentar um quadro mais severo da doença provocada pelo HRSV possui alguma alteração no sistema imune, seja imaturidade, deficiência ou supressão (recém-nascidos, idosos, imunossuprimidos e imunodeficientes), dificultando ainda mais a produção de uma vacina contra o HRSV (Greenberg e Piedra, 2004).

A primeira tentativa de se obter uma vacina foi feita utilizando-se vírus inativado por formalina, na década de 60. Durante os testes clínicos em seres humanos, notou-se que, apesar de induzirem uma forte reposta imune, essa vacina não era protetora (Kim et al., 1969) e quando estes indivíduos entraram em contato com o HRSV selvagem apresentaram manifestações muito mais severas da doença do que pessoas não vacinadas (cerca de $80 \%$ de hospitalizações e dois óbitos) (Dudas e Karron, 1998; Openshaw et al., 2001). O aumento da gravidade da doença foi analisado em animais e é resultado de diversos fatores: produção deficiente de anticorpos neutralizantes no soro, baixa imunidade local, deposição do complexo imune, indução de resposta exacerbada e aumento da produção de citocinas IL-4 e IL-5 (Durbin e Karron, 2003; Polack et al., 2002).

$\mathrm{Na}$ tentativa de obter proteção contra a infecção por HRSV, diversas estratégias vacinais foram formuladas (vírus recombinantes, peptídeos sintéticos, vacinas de DNA e vírus atenuados). No entanto, até o momento não existe uma vacina aprovada para o uso clínico, existindo alguns estudos que se encontram em fase de testes clínicos (Collins et al., 2001; Maggon e Barik, 2004).

\subsection{Tratamento}

O tratamento das infecções do TRI, causadas por HRSV, consiste na remoção mecânica das secreções, administração de oxigênio umidificado, posicionamento adequado da criança a fim de facilitar a respiração e em casos mais graves, assistência respiratória (Collins et al., 2001).

Embora exista a possibilidade de administração, em caráter preventivo, de um anticorpo monoclonal contra o HRSV para crianças que se encontram nos grupos de risco (Venkatesh e Weisman, 2006), não existe nenhum medicamento comprovadamente eficaz contra o HRSV. Outro ponto é o alto custo da administração desse anticorpo, limitando seu acesso. A única droga aprovada para o tratamento da infecção por HRSV é a Ribavirina (1- $\beta$-D-ribofuranosyl-1,2,4-triazole-3-carboxamide) (Virazole $\left.{ }^{\circledR}\right)$. Porém, há ainda muita controvérsia sobre os reais benefícios de seu uso (Kneyber et al., 2000; Prince, 2001; Van Woensel et al., 2001). 
Diante da falta de uma vacina eficaz, a imunoprofilaxia passiva pode ser feita com o uso de imunoglobulinas (Igs), porém para sua administração deve ser muito criteriosa, para evitar exacerbação da doença (Groothuis, 1994; Ottolini e Hemming, 1997). O risco associado à administração de grande quantidade de Igs, o alto custo e a necessidade de inúmeras visitas ao hospital, são fatores que limitam a utilização das imunoglobulinas (Ottolini e Hemming, 1997).

Uma terapia efetiva ainda não está disponível e a eficácia de corticoesteróides e broncodilatadores ainda não está bem definida. Estudos sobre a vitamina A, interferon e antibióticos são, até o momento, desapontadores (Kneyber et al., 2000).

A técnica de RNA de interferência (RNAi) vem sendo apontada como uma das mais promissoras, tanto para o tratamento quanto para a prevenção da infecção por HRSV (Barik e Bitko, 2006). Até o momento, apenas os genes NS1 e P foram testados como alvos para essa técnica, visando uma possível aplicação terapêutica. Nestes ensaios, verificou-se o sucesso da atividade antiviral do RNAi, tanto em cultura celular quanto em animais (Bitko et al., 2005; Zhang et al., 2005).

Estudos mundiais de amostras de HRSV com inserção de 60 nucleotídeos mostraram que há mutações sendo acumuladas e que a seleção positiva está influenciando na evolução desse vírus. A disseminação global desse genótipo sugere que pode estar havendo vantagens seletivas sobre os outros vírus circulantes. $\mathrm{O}$ conhecimento adquirido através de estudos de variabilidade genética do HRSV pode ter impacto não apenas sobre a evolução desse vírus, mas também sobre outras áreas, tais como o desenvolvimento de vacina. (Trento et al., 2006). 


\section{OBJETIVOS}

Estudar a variabilidade genética da segunda região de hipervariabilidade da proteína G de HRSV de amostras do grupo B, com inserção de 60 nucleotídeos.

Comparar região de inserção dos 60 nucleotídeos com a região anterior a esta, da qual origina-se a duplicação.

Analisar as modificações de aminoácidos e nucleotídeos ocorridas nessa região hipervariável desde 2001, através da comparação com amostras brasileiras obtidas no Laboratório de Virologia Clínica e Molecular nos anos de 2001 e 2003 a 2006. 


\section{MATERIAL E MÉTODO}

\subsection{Casuística}

A população estudada consistiu de 521 crianças com qualquer quadro clínico de doença respiratória aguda (DRA), menores de 5 anos de idade, atendidas na Enfermaria, Pronto Atendimento e na UTI (pediátrica e neonatal) na Clínica Pediátrica do Hospital Universitário da USP (HU/USP), distrito sanitário do Butantã, da cidade de São Paulo. Os espécimes foram colhidos, durante o ano de 2006, com consentimento dos pais ou responsáveis, que assinavam um Termo de Consentimento e com aprovação da Comissão de Ética Médica do Hospital Universitário e do Instituto de Ciências Biomédicas da USP (Anexo 1).

\subsection{Diagnóstico do HRSV}

\subsubsection{Colheita das amostras}

Foram colhidas amostras clínicas de aspirado de nasofaringe e $s w a b$ nasal das crianças assim que eram atendidas no Hospital Universitário da USP. O material colhido foi encaminhado, em gelo, para Laboratório de Virologia Clínica e Molecular do Instituto de Ciências Biomédicas da USP para serem processados.

\subsubsection{Processamento das amostras}

Em um período máximo de quatro horas após a colheita, o aspirado e o meio contendo o swab foram misturados, homogeneizados e tratados com 1000U/mL de penicilina e $1000 \mu \mathrm{g} / \mathrm{mL}$ de estreptomicina (Gibco BRL ${ }^{\circledR}$ ). Após 30 minutos a $4{ }^{\circ} \mathrm{C}$, as amostras (cerca de $3 \mathrm{~mL}$ ) foram separadas em 3 alíquotas: $900 \mu 1$ para inoculação em cultura de células; $250 \mu \mathrm{L}$ para RT-PCR, após acrescentar $750 \mu \mathrm{L}$ de Trizol LS (Gibco $\mathrm{BRL}^{\circledR}$ ), e o restante, cerca de $400 \mu \mathrm{L}$, foi armazenado a $-70{ }^{\circ} \mathrm{C}$ após adição de meio de congelamento, volume a volume (meio mínimo essencial Eagle - MEM), modificado com sais de Earle, com glutamina (Sigma Chemical Co., St. Louis, MO), acrescido de antibióticos, $10 \%$ de soro fetal bovino (SFB - Cultilab) e 10\% de glicerina esterilizada Sigma Chemical Co., St. Louis, MO). 


\subsection{RT-PCR}

\subsubsection{Extração do RNA total}

$\mathrm{Na}$ extração das amostras clínicas foi utilizada a alíquota estocada com Trizol LS.

Todo o processo de extração foi realizado em banho de gelo, com reagentes gelados e centrífuga refrigerada (Centrifugue 5804R Eppendorf). A $1 \mathrm{~mL}$ de aliquota (250 $\mu \mathrm{L}$ de aspirado com $750 \mu \mathrm{L}$ de Trizol LS) foram adicionados $200 \mu \mathrm{L}$ de clorofórmio: álcool isoamílico 24:1 (Merck-Sigma). Após a homogeneização em vórtex por 15 segundos e incubação por 5 minutos em banho de gelo, a amostra foi centrifugada a $12000 \mathrm{rpm}$ por 15 minutos a $4{ }^{\circ} \mathrm{C}$. A fase aquosa, cerca de $400 \mu \mathrm{L}$, foi transferida para outro tubo, sendo o RNA precipitado pela adição de isopropanol (Sigma Chemical Co., St. Louis, MO) volume a volume, seguido de homogeneização em vórtex, incubação em banho de gelo por 15 minutos e centrifugação a $12000 \mathrm{rpm}$ por 15 minutos a $4{ }^{\circ} \mathrm{C}$. A seguir, o sobrenadante foi descartado e o precipitado lavado com 800 $\mu \mathrm{L}$ de etanol a 75\% (Merck) diluído em água Milli- $\mathrm{Q}^{\circledR}$ tratada com DEPEC (Dietilpirocarbonato - Sigma Chemical Co., St. Louis, MO), seguido de centrifugação a $8000 \mathrm{rpm}$ por 8 minutos a $4{ }^{\circ} \mathrm{C}$. O sobrenadante foi descartado e o precipitado foi novamente suspenso em $20 \mu \mathrm{L}$ de água tratada com DEPEC contendo $40 \mathrm{U}$ de Inibidor de Ribonuclease (Rnasin ${ }^{\circledR}$ - Promega Product, Information).

\subsubsection{Obtenção do DNA complementar (cDNA)}

A transcrição reversa foi realizada utilizando High Capacity cDNA Archive kit (Applied Biosystems ${ }^{\circledR}$ ), sendo utilizado termociclador (Mastercycler Personal Eppendorf) a $25^{\circ} \mathrm{C}$ por 10 minutos seguido de $37^{\circ} \mathrm{C}$ por 2 horas.

\subsubsection{Primers utilizados no diagnóstico do HRSV}

As seqüências alvos, para diagnóstico do HRSV, são regiões da subunidade F1 do gene de glicoproteína de fusão, ressaltando que o primer sense possuía um marcador fluorescente (FAM-Gibco BRL) para leitura no GeneScan (Tabela 2). 
Tabela 2 - Características dos primer utilizados para o diagnóstico de HRSV.

\begin{tabular}{|c|c|c|c|c|c|}
\hline \begin{tabular}{|c|} 
Identificação do \\
Primer
\end{tabular} & Gene & Localização & Polaridade & Seqüência & $\begin{array}{c}\text { Tamanho } \\
\text { (bp) }\end{array}$ \\
\hline $\begin{array}{l}\text { R S V A B - F } 1 \text { - } \\
\text { FAM }\end{array}$ & \multirow[t]{2}{*}{$F$} & $1111-1134$ & + & $\begin{array}{c}\text { AACAGTTTAACATTACCAAGTG } \\
\text { A }\end{array}$ & \multirow[t]{2}{*}{380} \\
\hline RSVAB-R1 & & $1468-1490$ & - & TCATTGACTTGAGATATTGATGC & \\
\hline
\end{tabular}

FONTE: Mazzulli et al., 1999

\subsubsection{PCR diagnóstico para HRSV}

A reação de PCR foi realizada utilizando o cDNA obtido logo após o processo de extração.

A amplificação é efetuada com a diluição de $3 \mu \mathrm{L}$ de cDNA em tampão $20 \mathrm{mM}$ de Tris- $\mathrm{HCl}[\mathrm{pH} 8.4] / 50 \mathrm{mM}$ de $\mathrm{KCl} / 1.5 \mathrm{mM}$ de $\mathrm{MgCl}_{2}$ (Biotools), 25 pMoles de cada primer (tabela 2), $1 \mathrm{U}$ de Taq DNA Polimerase (Biotools), $0.2 \mathrm{mM}$ de cada dNTP e água UltraPure DNAse free RNAse free q.s.p. $25 \mu \mathrm{L}$. A reação é amplificada em termociclador GeneAmp PCR System 9700 (Applied Biosystems), a partir de uma etapa $94{ }^{\circ} \mathrm{C}$ por $5^{\prime}$ seguida de 35 ciclos de $94{ }^{\circ} \mathrm{C}$ por 1 '/ $54{ }^{\circ} \mathrm{C}$ por 1 ' / $72{ }^{\circ} \mathrm{C}$ por $1^{\prime}$ e uma etapa final de $72{ }^{\circ} \mathrm{C}$ por 7 '.

\subsubsection{Detecção dos produtos amplificados (GeneScan)}

Os produtos de PCR foram analisados utilizando o Analisador Automático de DNA ABI Prism modelo 310, com detecção para marcadores fluorescentes, utilizando o programa Genescan para quantificação e análise de fragmento de DNA. $1 \mu \mathrm{L}$ do produto de PCR é misturado com $11 \mu \mathrm{L}$ de formamida deionizada e $0,75 \mu \mathrm{L}$ de size standard (GeneScan ${ }^{\mathrm{TM}}-500 \mathrm{ROX}^{\mathrm{TM}}$ STANDARD). A inclusão do padrão de peso molecular em cada amostra permite a compensação de eventuais variações que pudessem ocorrer entre as corridas de eletroforese. Essa mistura é colocada no Termociclador para desnaturação $\quad\left(95^{\circ} \mathrm{C}\right.$ por 3 minutos $)$ e imediatamente colocada em gelo até a análise no aparelho.

Os produtos são submetidos à corrida de eletroforese de DNA no ABI modelo 310 (Applied Biosystems ${ }^{\circledR}$ ), utilizando-se de um capilar medindo $47 \mathrm{~cm}$ de comprimento, preenchido por um polímero POP-4 (Applied Biosystems ABI ®). A injeção da amostra no capilar dura 5 segundos sob uma corrente elétrica de 15.000 
volts. Após a injeção, inicia-se a corrida que dura cerca de 30 minutos para cada amostra à temperatura de $60^{\circ} \mathrm{C}$.

Os fragmentos marcados são detectados por um feixe a laser e por uma câmara CCD utilizando-se um filtro virtual "A", que em seguida são analisados pelo programa ABI 310 Genescan (Applied Biosystems ${ }^{\circledR}$ ), produzindo eletroferogramas com dados quanto ao tamanho dos fragmentos em pares de bases (pb) e quanto à intensidade de fluorescência em Unidades relativas de Fluorescência (URF).

\subsection{Amplificação da seqüência parcial do gene codificador da proteína $G$}

As amostras positivas para HRSV foram submetidas a PCR. $5 \mu \mathrm{L}$ do cDNA foram diluídos em tampão de reação - $10 \mathrm{mM}$ tris - $\mathrm{HCl}[\mathrm{pH}-9.0], 1,5 \mathrm{mM} \mathrm{MgCl} ; 50$ mM de KCl (PCR buffer 10X - Amersham Pharmacia Biotech), 0,2 mM de cada dNTP, 2,5 U de Taq DNA polimerase (Amersham Pharmacia Biotech), 50 pmol de cada primer (FV e GR5: tabela 3 e figura 5) e água Milli-Q ${ }^{\circledR}$ tratada com DEPEC para completar $50 \mu \mathrm{L}$. A amplificação foi feita no termociclador GeneAmp PCR System 2400 , com pré aquecimento a $95{ }^{\circ} \mathrm{C}$ por 5 minutos, seguida de 35 ciclos, cada um deles composto de 1 minuto a $94{ }^{\circ} \mathrm{C}$ para desnaturação do DNA molde, 1 minuto a $55{ }^{\circ} \mathrm{C}$ para o emparelhamento dos primers e 1 minuto a $72{ }^{\circ} \mathrm{C}$ para a extensão das novas cadeias. Findos os ciclos segui-se um aquecimento a $72{ }^{\circ} \mathrm{C}$ por 7 minutos de extensão final.

Tabela 3 - Descrição dos primer utilizados para o sequenciamento parcial do gene G do HRSVLocalização de cada primer no genoma viral, polaridade, seqüência 5' - 3' e o tamanho do amplicon.

\begin{tabular}{|c|c|c|c|c|c|}
\hline Primer & Gene & Localização & Polaridade & Seqüência & $\begin{array}{c}\text { Tamanho do } \\
\text { produto }(\mathrm{pb})\end{array}$ \\
\hline FV $^{1}$ & $\mathrm{~F}$ & $186-163$ & - & GTTATGACACTGGTATACCAACC & \multirow{2}{*}{$\sim 1000$} \\
\hline Gr5 $^{2}$ & $\mathrm{G}$ & $151-173$ & + & CTGGCAATGATAATCTCAACTTC & $\sim 1000$ \\
\hline
\end{tabular}

${ }^{1}$ Zheng et al., 1996

${ }^{2}$ Sanz et al., 1994 


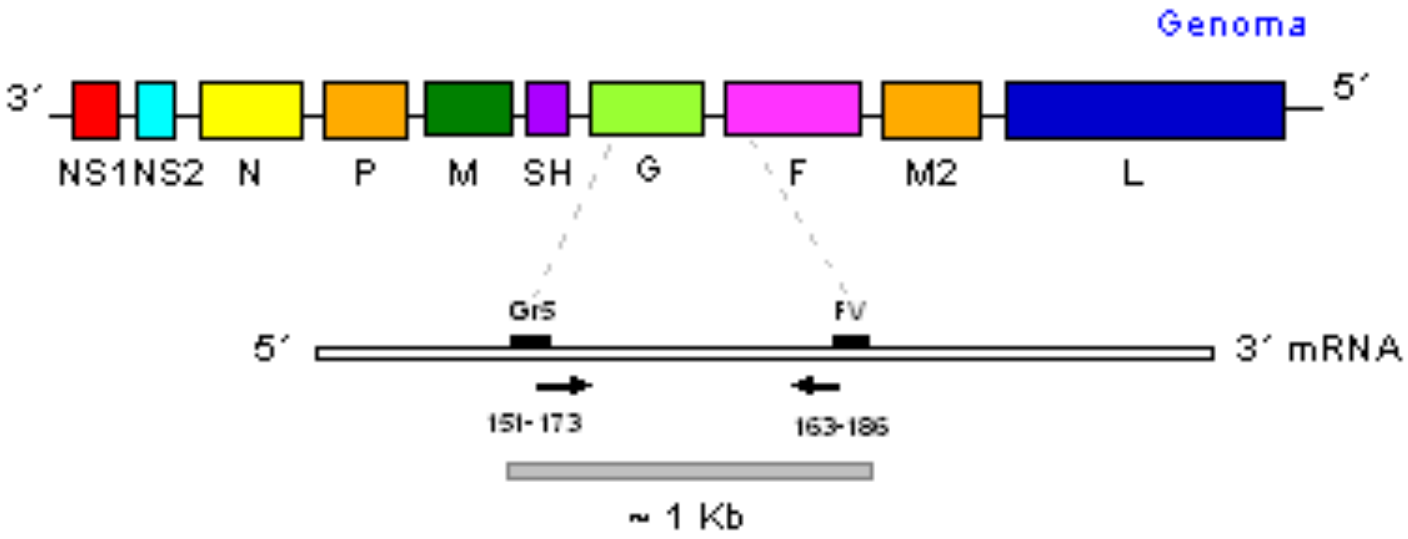

Figura 5 - Esquema do genoma viral, emparelhamento dos primers: Os genes estão identificados de acordo com a proteína que codificam e estão listados logo abaixo do esquema do genoma viral. Os retângulos pretos indicam a localização dos primers e seu emparelhamento com as fitas alvo. O tamanho esperado do produto amplificado está indicado pelo retângulo cinza.

\subsection{Análise dos produtos amplificados}

A detecção do produto amplificado pela PCR foi realizada por eletroforese em gel de agarose $\left(\right.$ Gibco $B R L^{\circledR}$ ) a 2,0\% em tampão TBE 0.5x (45 mM de Tris-Borato e 1 $\mathrm{mM}$ de EDTA [pH 8.0]) e $0,5 \mu \mathrm{g} / \mathrm{mL}$ brometo de etídeo. Uma mistura de $10 \mu \mathrm{L}$ da amostra e $2 \mu \mathrm{L}$ azul de bromofenol (loading buffer) foi submetida à eletroforese, em cuba horizontal $\left(\right.$ Gibco BRL ${ }^{\circledR}$ ), em tampão TBE durante 40 minutos a $100 \mathrm{~V}$. A visualização do gel foi realizada em transiluminador de luz ultravioleta (UV), sendo fotografado, a seguir, para uma análise mais detalhada.

\subsection{Precipitação e purificação do produto amplificado}

Os produtos amplificados pela PCR foram precipitados, pela ação de acetato de sódio (pH 5,25) (Merck-Sigma). Para cada 40 $\mu \mathrm{L}$ de reação de PCR, acrescentou-se $10 \mu \mathrm{L}$ de água UltraPure DNAse free RNAse free, completando um volume de $50 \mu \mathrm{L}$. A essa mistura foi acrescentado $5 \mu \mathrm{L}$ de acetato de sódio e $110 \mu \mathrm{L}$ de etanol $100 \%$. As amostras permaneceram em freezer $-70^{\circ} \mathrm{C}$ por 3 horas, para uma precipitação eficiente.

Os tubos foram centrifugados durante 30 minutos a $14000 \mathrm{rpm}$ a $4{ }^{\circ} \mathrm{C}$. O sobrenadante foi descartado e adicionado $150 \mu \mathrm{L}$ de Etanol 75\%. Os tubos foram centrifugados por 10 minutos a $14000 \mathrm{rpm}$ a $4{ }^{\circ} \mathrm{C}$. O sobrenadante foi descartado e o 
pellet foi submetido ao speed-vacuum a $60{ }^{\circ} \mathrm{C}$ por 20 minutos, para secar. O pellet foi ressuspenso em $50 \mu \mathrm{L}$ de água UltraPure DNAse free RNAse free.

Alíquotas do produto purificado foram submetidas à eletroforese em gel de agarose a $1,5 \%$ e seu tamanho foi estabelecido com o auxílio de marcador de peso molecular (1Kb DNA Mass Ladder - Gibco BRL $\left.{ }^{\circledR}\right)$.

\subsection{Seqüenciamento parcial do gene G do HRSV}

Após a purificação, as fitas de DNA foram seqüenciadas utilizando-se o kit “ABI PRISM Dye TM Terminator Cycle Sequencing Ready Reaction kit" ("Big Dye" Applied Biosystems, Inc., EUA), seguindo as instruções do fabricante.

Foram utilizados os primers FV e GR5 (tabela 3) para o seqüenciamento das variantes do grupo A e B de HRSV. Cerca de $3 \mu \mathrm{L}$, correspondendo a 10-30 ng, do produto purificado, foram adicionados a um microtubo com 1,6 pmol de primer, $2 \mu \mathrm{L}$ do "Terminator ready reaction Mix, Big Dye", $2 \mu \mathrm{L}$ do tampão de seqüenciamento (save money - Tris $\mathrm{HCl} 200 \mathrm{mM}$ [pH 9,0] e $5 \mathrm{mM} \mathrm{MgCl}_{2}$ ) e água Milli-Q ${ }^{\circledR}$ para completar um volume final de $10 \mu \mathrm{L}$. Todas as reações foram feitas em duplicatas com ambos os primers.

A extensão enzimática foi realizada em termociclador GeneAmp PCR System 2400 durante 25 ciclos de $96^{\circ} \mathrm{C}$ por 10 segundos para a desnaturação do DNA molde, $50{ }^{\circ} \mathrm{C}$ por 10 segundos para o emparelhamento dos primers e $60{ }^{\circ} \mathrm{C}$ por 4 minutos para a extensão.

O produto obtido foi purificado, visando à remoção de excesso de dideoxinucleotídeos "terminadores" presentes na reação, por precipitação com isopropanol a $75 \%$, seguido de lavagem com etanol a $75 \%$.

As amostras purificadas foram re-suspendidas em uma solução de Formamida Hi-DiTM (Applied Biosystems, Inc., EUA) e submetidas à eletroforese em Polímero 3100 POP-6 ${ }^{\mathrm{TM}}$, utilizando seqüenciador automático ABI modelo 3100 (Applied Biosystems, Inc., EUA). 


\subsection{Processamento e alinhamento das seqüências do gene G do HRSV}

As seqüências de nucleotídeos foram analisadas com o programa Sequence Navigator versão 1.0 (Applied Biosystems, Inc., EUA) para Power Macintosh. Posteriormente, essas seqüências foram traduzidas utilizando o programa Edit Seq ${ }^{\mathrm{TM}}$ 4,05 - Expert Analysis Software - DNASTAR, Inc para PC.

As seqüências de nucleotídeos e aminoácidos foram alinhadas em dois grupos, A e B, utilizando o programa Meg Align ${ }^{\mathrm{TM}} 4.05$ - Expert Analysis Software DNASTAR, Inc., EUA para PC. Ambos foram analisados, separadamente, com o referido programa, tendo como resultado a obtenção do grau de similaridade entre as seqüências, calculadas par a par, o que possibilitou a identificação das seqüências de nucleotídeos idênticas.

Com o intuito de otimizar as análises subseqüentes, tomou-se, aleatoriamente, apenas uma amostra de cada grupo de seqüências idênticas.

Para genotipagem as seqüências de nucleotídeos do grupo A foram comparadas com outras seqüências adquiridas do GenBank, incluindo os protótipos A2 e Long, e outras seqüências representando os principais genotipos (GA1 a GA7, SAA1), descritos por PERET et al. (1998, 2000) (Anexo 2), e com seqüências obtidas durante os anos de 2001 a 2005 no laboratório de Virologia Clínica e Molecular do Insituto de Ciências Biomédicas da USP, gentilmente cedidas por Dra. Viviane Fongaro Botosso.

As seqüências de nucleotídeos do grupo B foram comparadas com outras seqüências adquiridas do GenBank, incluindo os protótipos Sw8/60, CH18537 e com seqüências obtidas durante os anos de 2001 a 2005 no laboratório de Virologia Clínica e Molecular do Insituto de Ciências Biomédicas da USP, gentilmente cedidas por Dra. Viviane Fongaro Botosso (Botosso et al., 2004; Moraes et al., 2005 - Anexo 3).

\subsection{Análises genealógicas}

As análises genealógicas entre as cepas de HRSV dos grupos A e B foram realizadas empregando o critério de distância evolutiva utilizando o programa PAUP*4.0 versão Beta - Sinauer Associates, Inc, (SWOFFORD, 1998), para Power Macintosh. Os alinhamentos obtidos inicialmente com o programa Meg Align $^{\mathrm{TM}} 4.05$ foram convertidos em arquivos no formato NEXUS e utilizados para as análises subseqüentes. 
Inicialmente realizou-se o teste de razão de verossimilhança para a escolha do modelo evolutivo a ser utilizado, com auxílio do programa Modeltest versão 3.06 (David Posada, Department of Zoology, Brigham Young University, USA). Uma vez escolhido o modelo, foi realizada uma busca heurística com o algoritmo de neigboor joing. 


\section{RESULTADOS}

No ano de 2006, 521 amostras de aspirado de nasofaringe de crianças menores de 5 anos de idade, atendidas no HU-USP, foram testadas pela RT-PCR-GeneScan, para a presença de HRSV, sendo o vírus detectado em 184 (35,3\%) dessas amostras. Para a análise da evolução das amostras pertencentes ao grupo B com inserção, foram incluídos no estudo seqüências obtidas no Laboratório de Virologia Clínica e Molecular do ICB/USP durante os anos de 2001 a 2005. Os estudos realizados durante 2001 e 2002 incluíram apenas crianças menores de 1 ano de idade, enquanto nos anos subseqüentes crianças menores de 5 anos, admitidas na Clínica Pediátrica do HU/USP. Um total de 1289 crianças foram estudadas e os resultados estão resumidos na tabela 4.

A amplificação das amostras utilizando os primers FV(-) e Gr5(+) gerou um produto de aproximadamente $980 \mathrm{pb}$, porém algumas amostras positivas não foram amplificadas.

Dentre as amostras positivas, $38(20,6 \%)$ foram parcialmente seqüenciadas para identificação do grupo e do genótipo.

Para estabelecer a comparação entre as seqüências de vírus do grupo B com inserção, identificadas neste trabalho, foram utilizadas outras amostras seqüenciadas no Laboratório de Virologia Clínica e Molecular (ICB-USP) durante os anos de 2001 e de 2003 a 2005. No ano de 2002 nenhuma amostra seqüenciada foi genotipada como pertencente ao grupo B com inserção (dados gentilmente cedidos pela Dra. Viviane F. Botosso).

O número de amostras testadas para HRSV por imunofluorescência e/ou RT-PCR, a taxa de positividade e o grupo ao qual tais amostras pertencem podem ser observados na Tabela 4.

Após o seqüenciamento das amostras positivas de 2006 para HRSV, foram encontradas $12(31,6 \%)$ amostras pertencentes ao grupo A e 26 $(68,4 \%)$ pertencentes ao grupo B. Essas amostras foram genotipadas, utilizando seqüências depositadas no GenBank, a fim de estabelecer as árvores filogenéticas do grupo A e B (Figura 6 e 7 - árvores filogenéticas. Anexo 2 - amostras depositadas no GenBank utilizadas na comparação). 


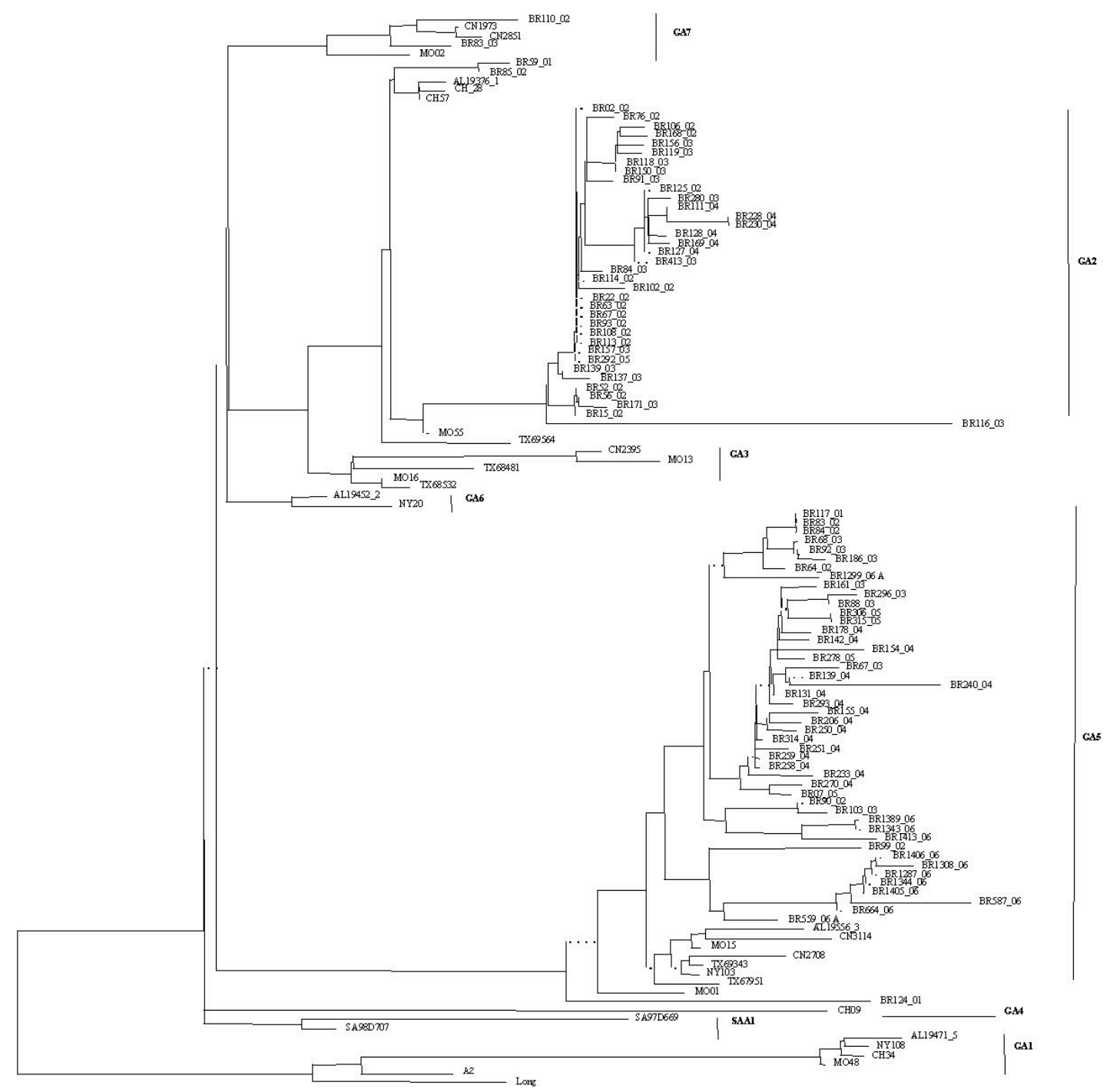

0.005 substitutions/site

Figura 6 - Análise filogenética do hRSV grupo A. Seqüências parciais do gene da proteína $\mathrm{G}$ isoladas no Brasil (BR) comparadas com seqüências disponíveis no GeneBank. 


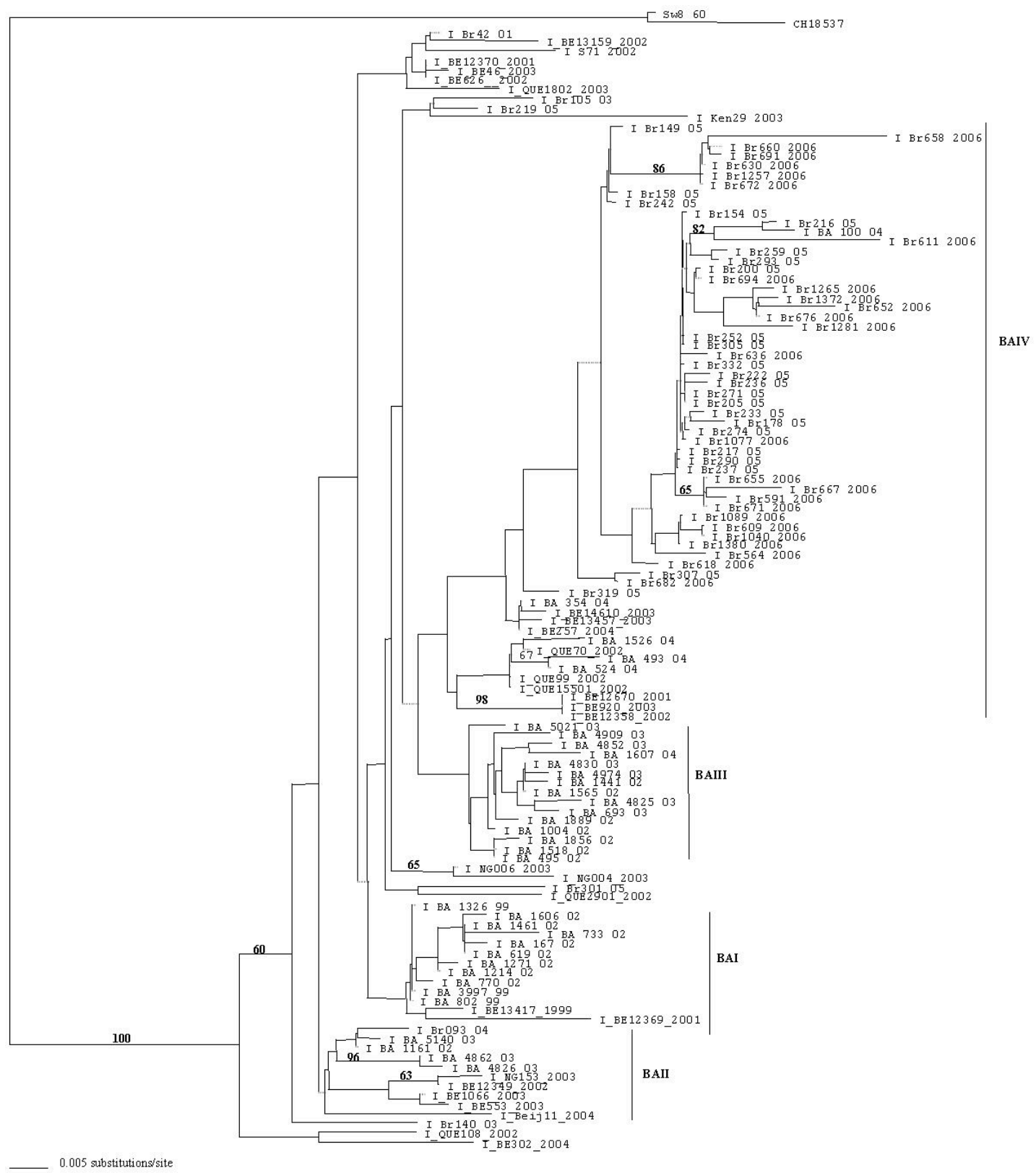

Figura 7 - Análise filogenética do hRSV grupo B com inserção. Seqüências parciais do gene da proteína $\mathrm{G}$ isoladas no Brasil (BR) comparadas com seqüências disponíveis no GeneBank. O valor de Bootstrap obtidos por Distância, está demonstrado sobre os ramos. A classificação em BA I, BA II, BA III e BA IV foi feita segundo Trento et al.(2006).

Entre as amostras analisadas o grupo A foi mais freqüente em relação ao grupo B, sendo encontrado em $59,2 \%$ das amostras seqüenciadas. Todavia nos anos 2001, 2005 e 2006, o grupo B apresentou-se mais freqüentemente (Tabela 4). 
Tabela 4 - Distribuição do HRSV durante seis anos consecutivos (2001-2006). Amostras colhidas no Hospital Universitário da Universidade de São Paulo, São Paulo, Brasil.

\begin{tabular}{|c|c|c|c|c|}
\hline \multirow[b]{2}{*}{ Ano } & \multirow[b]{2}{*}{$\begin{array}{l}\text { Número de amostras } \\
\text { testadas para HRSV }\end{array}$} & \multirow[b]{2}{*}{$\begin{array}{l}\text { Amostras positivas } \\
\text { (IF e/ou RT-PCR) }\end{array}$} & \multicolumn{2}{|c|}{ Grupo* } \\
\hline & & & A & B \\
\hline$\$ 2001$ & 127 & $29(22,8 \%)$ & 4 & 13 \\
\hline$\$ 2002$ & 165 & $50(30,3 \%)$ & 12 & 2 \\
\hline$\S 2003$ & 336 & $81(24,1 \%)$ & 38 & 5 \\
\hline$\S 2004$ & 435 & $188(43,2 \%)$ & 45 & 8 \\
\hline$\S 2005$ & 226 & $102(45,1 \%)$ & 8 & 28 \\
\hline$\S 2006$ & 521 & $184(35,3 \%)$ & 12 & 26 \\
\hline Total & 1810 & $634(35,0 \%)$ & $119(59,2 \%)$ & $82(40,8 \%)$ \\
\hline
\end{tabular}

*A amostras foram divididas em dois grupos através da caracterização molecular.

$\$$ Nos anos de 2001 e 2002 apenas crianças menores de um ano de idade foram incluídas no estudo.

$\S$ Nos anos de 2003 a 2006 foram incluídas no estudo crianças menores de cinco anos de idade.

Em 2006, todas as amostras do grupo A foram classificadas no genótipo GA5. A distribuição dos genótipos das amostras do grupo A dos anos 2001 a 2006 pode ser observada na Tabela 5.

Os genótipos descritos na literatura, mas não encontrados nessa amostragem não foram incluídos nessas tabelas 5 e 6 .

Tabela 5 - Distribuição genotípica das amostras do grupo A durante seis estações (2001-2006) em São Paulo, Brasil.

\begin{tabular}{ccccc}
\hline Ano & GA2 & GA5 & GA7 & Total \\
\hline $\mathbf{2 0 0 1}$ & $1(25,0 \%)$ & $3(75,0 \%)$ & - & 4 \\
$\mathbf{2 0 0 2}$ & $25(75,7 \%)$ & $7(21,2 \%)$ & $1(3,0 \%)$ & 33 \\
$\mathbf{2 0 0 3}$ & $19(50,0 \%)$ & $18(47,4 \%)$ & $1(2.6 \%)$ & 38 \\
$\mathbf{2 0 0 4}$ & $18(40,0 \%)$ & $27(60,0 \%)$ & - & 45 \\
$\mathbf{2 0 0 5}$ & $2(25,0 \%)$ & $6(75,0 \%)$ & - & 8 \\
$\mathbf{2 0 0 6}$ & - & $12(100 \%)$ & - & 12 \\
Total & $65(46,4 \%)$ & $73(52,1 \%)$ & $2(1,4 \%)$ & 140 \\
\hline
\end{tabular}

A distribuição dos genótipos do grupo B, de 2001 a 2006, mostrou que, dentre as amostras analisadas, nos anos de 2005 e 2006 a maioria foi do genotipo B com inserção, sendo que todas as amostras de 2006, apresentaram a inserção de 60 nucleotídeos (Tabela 6). 
Tabela 6 - Distribuição genotípica das amostras do grupo B, nos anos de 2001-2006, São Paulo, Brasil.

\begin{tabular}{cccccc}
\hline Ano & GB3 & SAB1 & SAB3 & B + ins* & Total \\
\hline $\mathbf{2 0 0 1}$ & - & $1(16.7 \%)$ & $3(50,0 \%)$ & $2(33,3 \%)$ & 6 \\
$\mathbf{2 0 0 2}$ & - & - & $12(100 \%)$ & - & 12 \\
$\mathbf{2 0 0 3}$ & - & $1(20,0 \%)$ & $2(40,0 \%)$ & $2(40,0 \%)$ & 5 \\
$\mathbf{2 0 0 4}$ & - & $1(25,0 \%)$ & $2(50,0 \%)$ & $1(25,0 \%)$ & 4 \\
$\mathbf{2 0 0 5}$ & $4(12,9 \%)$ & - & $1(3,2 \%)$ & $26(83,9 \%)$ & 31 \\
$\mathbf{2 0 0 6}$ & - & - & - & $26(100 \%)$ & 26 \\
Total & $2(2,4 \%)$ & $3(3,6 \%)$ & $20(23,8 \%)$ & $57(67,8 \%)$ & 84 \\
\hline
\end{tabular}

* Amostras do grupo B com inserção de 60 nucleotídeos

As amostras do grupo B com inserção dos anos 2001 a 2006 foram analisadas quanto à variabilidade dos aminoácidos e dos nucleotídeos.

A comparação das seqüências com o consenso, iniciando-se no aminoácido 213, mostrou as seguintes alterações:

- Quatro amostras de 2006 sofreram alteração do nucleotídeo $\mathrm{G}^{643} \rightarrow$ A, modificando o aminoácido correspondente $\mathrm{R}^{214} \rightarrow \mathrm{K}$.

- Cinco amostras de 2006 sofreram alteração no nucleotídeo $\mathrm{C}^{647} \rightarrow$ T, sem alteração de aminoácido.

- Nove amostras, das quais seis eram de 2006, uma de 2003, uma de 2004 e uma de 2005, sofreram alteração do nucleotídeo $\mathrm{T}^{658} \rightarrow \mathrm{C}$, resultando na modificação de $\mathrm{L}^{219} \rightarrow \mathrm{P}$.

- Vinte e uma amostras de 2005 e todas as amostras de 2006 sofreram alteração do nucleotídeo $\mathrm{C}^{689} \rightarrow \mathrm{T}$, sem alteração do aminoácido.

- Quatro amostras de 2006 sofreram mutação no nucleotídeo C $716 \rightarrow$ $\mathrm{T}$ e outras quatro $\mathrm{C}^{761} \rightarrow \mathrm{A}$, ambos os casos resultaram em mutações sinônimas.

- Nove amostras (uma de 2001, uma de 2002, uma de 2004 e seis de 2006) sofreram alteração no nucleotídeo $T^{804} \rightarrow C$, alterando o aminoácido $\mathrm{S}^{268} \rightarrow \mathrm{P}$. 
- Dez amostras, incluindo seis amostras de 2006, sofreram alteração no nucleotídeo $\mathrm{T}^{814} \rightarrow \mathrm{C}$, resultando em modificação de aminoácido de $\mathrm{I}^{271} \rightarrow \mathrm{T}$.

- Quarenta e quatro amostras (21 em 2006 e 23 em 2005) apresentaram modificação do nucleotídeo $\mathrm{T}^{817} \rightarrow \mathrm{C}$, alterando o aminoácido de $\mathrm{V}^{272} \rightarrow \mathrm{A}$.

- Seis amostras de 2006 sofreram modificação do nucleotídeo $\mathrm{T}^{820} \rightarrow$ $\mathrm{C}$, alterando o aminoácido de $\mathrm{L}^{273} \rightarrow \mathrm{P}$.

- Quarenta e três amostras (21 em 2006, 21 em 2005 e 1 em 2003) apresentaram modificação do nucleotídeo $\mathrm{C}^{864} \rightarrow \mathrm{T}$, modificando o aminoácido $\mathrm{H}^{288} \rightarrow \mathrm{Y}$.

- Todas as amostras de 2006 apresentaram o stop códon no aminoácido 314, porém algumas amostras referentes aos outros anos, sofreram mutação em um nucleotídeo que codifica para o aminoácido de terminação, fazendo com que a leitura continuasse. Em uma amostra de 2003, uma de 2004 e uma de 2005, graças à mutação no stop códon, essas seqüências apresentam dois aminoácidos a mais. Em outras quatro seqüências (2001, 2003 e 2005), a mutação provocou o alongamento da seqüência em mais 6 aminoácidos. 


\section{DISCUSSÃO}

O HRSV é o agente viral mais freqüentemente encontrado nas doenças respiratórias durante a infância, principalmente em idade pré-escolar (Anderson et al., 1990; Cane et al., 2001; Hall, 1994). Estudos realizados no Brasil, sobre a incidência do vírus, apontaram o HRSV como responsável por 17 a $68 \%$ das infecções virais em crianças internadas (Calegari et al., 2005, Moura et al., 2003; Serafino et al., 2004; Thomazelli et al., 2007 Vieira et al., 2001). Nesse estudo, foi encontrado índice de positividade de $35 \%$ de HRSV entre as amostras de crianças atendidas no HU-USP, durante o período de 2001 a 2006.

Anderson e colaboradores (1985) dividiram o HRSV em dois grupos, A e B, de acordo com a reatividade com painel de anticorpos monoclonais. Posteriormente, estudos genéticos demonstraram que os dois grupos antigênicos correspondem também a grupos geneticamente distintos (Cristina et al., 1990). Estudo de seqüências, de ambos os grupos, determinaram que a glicoproteína G apresenta a maior diversidade (Johnson et al., 1987).

O seqüenciamento, para tipagem das amostras, foi realizado utilizando os primers descritos por Sanz et al., (1994) e Zheng et al., (1996). O resultado da PCR, com utilização desses primers, é um produto de 980 pb, porém nesse trabalho somente foi utilizada a segunda região variável do gene codificador da glicoproteína $G$ (aproximadamente $330 \mathrm{pb}$ ), na qual a inserção de 60 nucleotídeos está localizada.

Segundo Campos (2006), a região G2, segunda região variável do gene da proteina $\mathrm{G}$, é suficiente para a genotipagem do HRSV, uma vez que as amostras não apresentaram mudança de genótipo, quando comparado ao genótipo obtido através da seqüência inteira deste. 
A circulação dos grupos A e B pode apresentar grande variação de local para local e de ano para ano. Embora o grupo A seja mais freqüentemente isolado do que o grupo B, pode ocorrer a co-circulação de ambos os grupos em certos surtos e casos em que isolados do grupo B mostraram-se predominantes (Botosso, 2002; Hendry et al., 1986; Martinez et al., 1999, Zlateva et al., 2007).

Em nosso estudo, foi observada a co-circulação dos grupos A e B. Como descrito na literatura, o grupo A predominou sobre o grupo B, com $59,2 \%$ nesse período de seis anos, contudo, houve anos $(2001,2005$ e 2006) em que o grupo B foi o mais prevalente.

Sullender (2000) demonstrou que, embora haja diversas nomenclaturas adotadas, os agrupamentos dos isolados de HRSV em genótipos são muito semelhantes entre as diversas publicações sobre o assunto. Amostras designadas por Peret et al. (1998) como GA1 a GA5 correspondem ao genótipo, baseado no seqüenciamento parcial dos genes SH e G, feitos por Cane e Pringle (1991) e de Cane e colaboradores (1991) que utilizam a designação SHL1 a SHL5. A classificação em genótipos não é definitiva e pode variar de autor para autor, além de existir a possibilidade de criarem-se novas nomenclaturas para abranger novas amostras descritas, que não se encaixem nos parâmetros atuais. Novos genótipos estão sempre aparecendo enquanto outros passaram a não ser mais detectados (Cane, 2001).

No grupo A, observou-se a predominância do genótipo GA5 (52,1\%) e GA2 (46,4\%), porém no ano de 2006 apenas o genótipo GA5 foi encontrado. Zlateva e colaboradores (2007), em um estudo realizado na Bélgica, durante 10 anos sucessivos, encontrou predominância do genótipo GA5, porém também foram encontradas amostras GA2.

No grupo B, encontrou-se predominância do grupo B com inserção de 60 nucleotídeos, sendo que esse genótipo começou a predominar sobre os outros no ano de 2005 e foi o único observado em 2006. Zlateva e colaboradores (2007) descreveram a predominância desse genótipo, ao qual descrevem como GB13, entre as amostras do 
grupo B, sendo que nos anos de 2003 a 2006, esse foi o único genótipo circulante pertencente ao grupo B.

Trento e colaboradores (2006) propuseram uma classificação, para as amostras do grupo B com inserção de 60 nucleotídeos, na qual as amostras seriam divididas em BA-I, BA-II, BA-III e BA-IV, baseando-se na alteração de nucleotídeos em amostras belgas. As amostras de HRSV com inserção de 60 nucleotídeos na proteína $\mathrm{G}$, obtidas em 2005 e 2006, foram classificadas como BA-IV, a única amostra disponível de 2004 foi classificada como BA-II e as amostras de 2001 e 2003, assim como outras duas amostras de 2005 ficaram sem classificação por esse critério (Ver anexo 3).

Analisando o fragmento correspondente aos aminoácidos 213 ao 241, pertencentes à região G2, mas externos a duplicação e seu fragmento de origem, pudemos observar a presença de algumas mutações pontuais de aminoácidos em algumas amostras, sem correspondência em outras amostras. Apenas uma mutação que apareceu em 2003, de L para $\mathrm{P}$, foi freqüente nesse fragmento, sendo observada nos anos seguintes e sendo a maioria de 2006 .

Em 2004, uma amostra apresentou a inserção de um aminoácido na posição 233. Inserções de poucos aminoácidos são descritas na literatura (Sullender et al., 1991).

A análise de aminoácidos do fragmento anterior à duplicação (aminoácido 242 261), do qual tem origem à inserção de 60 nucleotídeos, mostrou que, entre as amostras brasileiras, sua variação é pequena. Apenas seis amostras apresentaram uma alteração de aminoácido cada, porém essa alteração não foi mantida nas outras amostras. $\mathrm{O}$ fragmento do qual origina-se a inserção pode ser considerado conservado.

Após o fragmento duplicado (do aminoácido $282 \mathrm{em}$ diante), as seqüências apresentam no aminoácido 288 uma alteração de nucleotídeo, que resultou na substituição do aminoácido na maioria das amostras de 2005 e 2006. Essa mutação parece ter se estabelecido desde 2005, apesar de ter sido encontrada também em uma amostra de 2003. 
No fragmento de 60 nucleotídeos (aminoácidos 262 a 281), observou-se dois pontos em que ocorreram modificações de nucleotídeo, alterando o aminoácido correspondente. No aminoácido 268, houve modificação de um $\mathrm{S}$ para $\mathrm{P}$ e no aminoácido 272 de $\mathrm{V}$ para $\mathrm{A}$, sendo esta última modificação foi observada na maioria das seqüências, podendo tratar-se de um sítio de pressão positiva.

O fragmento da inserção foi a região que mais apresentou alterações, dentre o segmento de seqüência analisado.

Os códons de terminação, ou stop codons, estão localizados na posição de número 314 em todas as amostras de 2006 e na maioria das amostras de 2005, porém em algumas amostras referentes aos outros anos, modificações em um nucleotídeo alteraram o stop codon, resultando em seqüências mais longa apresentando 316 e 321 aminoácidos. Esses dados estão de acordo com a literatura (Trento et al., 2006; Zlateva et al., 2007).

A região $\mathrm{C}$ terminal da proteína $\mathrm{G}$ apresenta relevância imunológica. É possível que a inserção de aminoácidos modifique a estrutura antigênica do gene da proteína $\mathrm{G}$, conferindo a vantagem evolucionária de reinfectar indivíduos previamente expostos ao vírus ancestral (Trento et al., 2003). 
- No ano de 2006, o grupo B foi predominante sobre o grupo A, porém se considerarmos todo o período de estudo (2001-2006) houve predominância do grupo A.

- Somente amostras do grupo B com inserção e amostras GA5 (grupo A) foram encontradas em 2006.

- Modificações de nucleotídeo podem alterar o códon de terminação, gerando proteínas com diferentes quantidades de aminoácidos.

- A inserção de 60 nucleotídeos de amostras B de HRSV pode estar levando a mecanismos de escape desse vírus do sistema imunológico.

- Alterações na região de inserção podem ajudar estudos de evolução do vírus.

- Estudos de variabilidade, principalmente aqueles com enfoque em regiões de importância imunológica, podem contribui não apenas para o entendimento da evolução do HRSV, como também para o desenvolvimento de vacinas. 


\section{REFERÊNCIAS BIBLIOGRÁFICAS}

Abels S, Nadal D, Stroehle A, Bossart W. Reliable detection of respiratory syncytial virus infection in children for adequate hospital infection control management. J Clin Microbiol. 2001 Sep; 39(9):3135-9.

Anas N, Boettrich C, Hall CB, Brooks JG. The association of apnea and respiratory syncytial virus infection in infants. J Pediatr. 1982; 101:65.

Anderson LJ, Hierholzer JC, Tsou C, Hendry RM, Fernie BF, McIntosh K, et al. Antigenic characterization of respiratory syncytial virus strains with monoclonal antibodies. J Infect Dis. 1985 Apr;151(4):626-33.

Anderson LJ, Bingham P, Hierholzer JC. Neutralization of respiratory syncytial virus by individual and mixtures of $\mathrm{F}$ and $\mathrm{G}$ protein monoclonal antibodies. J Virol. 1988 Nov; 62(11):4232-8.

Anderson LJ, Parker RA, Strikas RL. Association between respiratory syncytial virus outbreaks and lower respiratory tract deaths of infants and young children. J Infect Dis. 1990 Apr; 161(4):640-6.

Anderson LJ, Hendry RM, Pierik LT, Tsou C, McIntosh K. Multicenter study of strains of respiratory syncytial virus. J Infect Dis. 1991 Apr;163(4):687-92.

Arbiza J, Delfraro A, Frabasile S. Molecular epidemiology of human respiratory syncytial virus in Uruguay: 1985-2001--a review. Mem Inst Oswaldo Cruz. 2005 May; 100(3):221-30.

Arbiza J, Berois M, Delfraro A, Frabasile S, Mitoma FD, Milk R, et al. Genetic characterization of respiratory syncytial viruses isolated from consecutive acute respiratory infections in a HIV infected child. J Clin Virol. 2006 Jan;35(1):41-5.

Arens MQ, Swierkosz EM, Schmidt RR, Armstrong T, Rivetna KA. Enhanced isolation of respiratory syncytial virus in cell culture. J Clin Microbiol. 1986 Apr; 23(4):800-2.

Arruda E, Hayden FG, McAuliffe JF, Sousa MA, Mota SB, Mcauliffe MI, Geist FC, Carvalho EP, Fernandes MC, Guerrant RL, Gwaltney Jr JM 1991. Acute respiratory viral infections in ambulatory children of urban northeast Brazil. J Infect Dis. 164: 252-258.

De acordo com:

International Committee of Medical Journal Editors. Uniform requirements for manuscripts submitted to Biomedical Journal: sample references. Available from: http://www.icmje.org [2004 May 06]. 
Atreya PL, Peeples ME, Collins PL. The NS1 protein of human respiratory syncytial virus is a potent inhibitor of minigenome transcription and RNA replication. J Virol. $1998 \mathrm{Feb} ; 72(2): 1452-61$.

Avendaño LF, Parra J, Padilla C, Palomino MA. The influence of winter 2002 in pediatric health: dissociation between environmental factors and respiratory syncytial viruses, in Santiago. Rev Med Chil. 2003 Aug;131(8):902-8.

Barik S. Transcription of human respiratory syncytial virus genome RNA in vitro: requirement of cellular factor(s). J Virol. 1992 Nov;66(11):6813-8.

Barik S. The structure of the 5 ' terminal cap of the respiratory syncytial virus mRNA. J Gen Virol. 1993 Mar;74 ( Pt 3):485-90.

Barik S, Bitko V. Prospects of RNA interference therapy in respiratory viral diseases: update 2006. Expert Opin Biol Ther. 2006 Nov;6(11):1151-60.

Becnel D, You D, Erskin J, Dimina DM, Cormier SA. A role for airway remodeling during respiratory syncytial virus infection. Respir Res. 2005 Oct 21;6:122.

Bitko V, Musiyenko A, Shulyayeva O, Barik S. Inhibition of respiratory viruses by nasally administered siRNA. Nat Med. 2005 Jan;11(1):50-5.

Blanc A, Delfraro A, Frabasile S, Arbiza J. Genotypes of respiratory syncytial virus group B identified in Uruguay. Arch Virol. 2005 Mar;150(3):603-9.

Botosso, VF. Diversidade genética da glicoproteína $G$ entre amostras de Vírus Respiratório Sincicial isoladas na cidade de São Paulo, 1995-1998 [Tese]. São Paulo: Universidade de São Paulo; 2002.

Bruhn, F, Mokrohisky, ST, McIntosh K. Apnea associated with respiratory syncytial virus infection in young infants. J Pediatr. 1977; 90:382.

Buckingham SC, Bush AJ, Devincenzo JP. Nasal quantity of respiratory syncytical virus correlates with disease severity in hospitalized infants. Pediatr. Infect Dis, J. 2000 Feb; $19(2): 113-7$.

Calegari T, Queiroz DA, Yokosawa J, Silveira HL, Costa LF, Oliveira TF, et al. Clinicalepidemiological evaluation of respiratory syncytial virus infection in children attended in a public hospital in midwestern Brazil. Braz J Infect Dis. 2005 Apr;9(2):156-61.

Campos ACA. Correlação entre análise filogenética da glicoproteína $\mathrm{G}$ e genótipos de Vírus Respiratório Sincicial Humano (HRSV) em crianças admitidas no hospital Universitário da USP no ano de 2004 [Dissertação]. Instituto de Ciências Biomédicas: Universidade de São Paulo, São Paulo; 2006. 
Candeias JA. Isolation of the respiratory syncytial virus from children with acute respiratory infections. Rev Inst Med Trop Sao Paulo. 1967 Jan-Feb;9(1):27-30.

Cane PA, Matthews DA, Pringle CR. Identification of variable domains of the attachment $(\mathrm{G})$ protein of subgroup A respiratory syncytial viruses. J Gen Virol. 1991 Sep;72 ( Pt 9):2091-6.

Cane PA, Pringle CR. Evolution of subgroup A respiratory syncytial virus: evidence for progressive accumulation of amino acid changes in the attachment protein. J Virol. 1995 May;69(5):2918-25.

Carromeu, C. Estudos de caracterização estrutural, localização intracelular e imunogenicidade da RNA polimerase do Vírus Respiratório Sincicial Humano [tese]. Instituto de Ciências Biomédicas. São Paulo: Universidade de São Paulo; 2007.

Causse M, García-Mayorgas AD, Gutiérrez JB, Casal M. Preliminary evaluation of a multiplex reverse transcription-PCR assay combined with a new DNA chip hybridization assay for detecting respiratory syncytial virus. J Clin Microbiol. 2007 Nov; 45(11):3811-3.

Chanock R, Roizman B, Myers R. Recovery from infants with respiratory illness of a virus related to chimpanzee coryza agent (CCA). I. Isolation, properties and characterization. Am J Hyg. 1957a Nov;66(3):281-90.

Chanock R, Finberg L. Recovery from infants with respiratory illness of a virus related to chimpanzee coryza agent (CCA). II. Epidemiologic aspects of infection in infants and young children. Am J Hyg. 1957b Nov;66(3):291-300.

Chao RK, Fishaut M, Schwartzman JD, McIntosh K. Detection of respiratory syncytial virus in nasal secretions from infants by enzyme-linked immunosorbent assay. J Infect Dis. 1979 Apr;139(4):483-6.

Cheng X, Park H, Zhou H, Jin H. Overexpression of the M2-2 protein of respiratory syncytial virus inhibits viral replication. J Virol. 2005 Nov;79(22):13943-52.

Church, NR, Anas, NG, Hall, CB, Brooks, JG. Respiratory syncytial virus-related apnea in infants. Demographics and outcome. Am J Dis Child. 1984; 138:247.

Cintra OA, Owa MA, Machado AA, Cervi MC, Figueiredo LT, Rocha GM, Siqueira MM, Arruda E. Occurrence and severity of infections caused by subgroup A and B respiratory syncytial virus in children in southeast Brazil. J Med Virol. 2001 Oct;65(2): 408-12.

Coggins WB, Lefkowitz EJ, Sullender WM Genetic variability among group A and group B respiratory syncytial viruses in a children's hospital. J Clin Microbiol. 1998 Dec;36(12):3552-7. 
Collins PL, Wertz GW. cDNA cloning and transcriptional mapping of nine polyadenylylated RNAs encoded by the genome of human respiratory syncytial virus. Proc Natl Acad Sci U S A. 1983 Jun;80(11):3208-12.

Collins PL, Huang YT, Wertz GW. Identification of a tenth mRNA of respiratory syncytial virus and assignment of polypeptides to the 10 viral genes. J Virol. 1984 Feb; 49(2):572-8.

Collins PL, Mottet G. Membrane orientation and oligomerization of the small hydrophobic protein of human respiratory syncytial virus. J Gen Virol. 1993 Jul;74 ( Pt 7):1445-50.

Collins PL, Hill MG, Cristina J, Grosfeld H. Transcription elongation factor of respiratory syncytial virus, a nonsegmented negative-strand RNA virus. Proc Natl Acad Sci U S A. 1996 Jan 9;93(1):81-5.

Collins PL, Chanock RM, Murphy BR. Respiratory Syncytial Virus. In: Knipe DM, Howley PM, editors. Fields Virology. 4 ed. Philadelphia: Lippincott- Williams \& Wilkins; 2001. p. 1443-1485. 2v.

Cowton VM, McGivern DR, Fearns R. Unravelling the complexities of respiratory syncytial virus RNA synthesis. J Gen Virol. 2006 Jul;87(Pt 7):1805-21.

Cristina J, López JA, Albó C, García-Barreno B, García J, Melero JA, Portela A. Analysis of genetic variability in human respiratory syncytial virus by the RNase A mismatch cleavage method: subtype divergence and heterogeneity. Virology. 1990 Jan; 174(1):126-34.

Dickens LE, Collins PL, Wertz GW. Transcriptional mapping of human respiratory syncytial virus. J Virol. 1984 Nov;52(2):364-9.

Diniz EM, Vieira RA, Ceccon ME, Ishida MA, Vaz FA. Incidence of respiratory viruses in preterm infants submitted to mechanical ventilation. Rev Inst Med Trop Sao Paulo. 2005 Jan-Feb;47(1):37-44. Epub 2005 Feb 23.

Donaldson GC. Climate change and the end of the respiratory syncytial virus season. Clin Infect Dis. 2006 Mar 1;42(5):677-9.

Dudas RA, Karron RA. Respiratory syncytial virus vaccines. Clin Microbiol Rev. 1998 Jul;11(3):430-9.

Durbin AP, Karron RA. Progress in the development of respiratory syncytial virus and parainfluenza virus vaccines. Clin Infect Dis. 2003 Dec 15;37(12):1668-77. 
Escribano-Romero E, Rawling J, García-Barreno B, Melero JA. The soluble form of human respiratory syncytial virus attachment protein differs from the membrane-bound form in its oligomeric state but is still capable of binding to cell surface proteoglycans. $\mathrm{J}$ Virol. 2004 Apr;78(7):3524-32.

Falsey AR, Walsh EE. Respiratory syncytial virus infection in adults. Clin Microbiol Rev. 2000 Jul;13(3):371-84.

Fearns R, Collins PL. Role of the M2-1 transcription antitermination protein of respiratory syncytial virus in sequential transcription. J Virol. 1999 Jul;73(7):5852-64.

Fearns R, Peeples ME, Collins PL. Mapping the transcription and replication promoters of respiratory syncytial virus. J Virol. 2002 Feb;76(4):1663-72.

Fuentes S, Tran KC, Luthra P, Teng MN, He B. Function of the respiratory syncytial virus small hydrophobic protein. J Virol. 2007 Aug;81(15):8361-6. Epub 2007 May 9.

Galiano MC, Palomo C, Videla CM, Arbiza J, Melero JA, Carballal G. Genetic and antigenic variability of human respiratory syncytial virus (groups a and b) isolated over seven consecutive seasons in Argentina (1995 to 2001). J Clin Microbiol. 2005 May; 43(5):2266-73.

García-Barreno B, Palomo C, Peñas C, Delgado T, Perez-Breña P, Melero JA. Marked differences in the antigenic structure of human respiratory syncytial virus $F$ and $G$ glycoproteins. J Virol. 1989 Feb;63(2):925-32.

García-Barreno B, Delgado T, Melero JA. Identification of protein regions involved in the interaction of human respiratory syncytial virus phosphoprotein and nucleoprotein: significance for nucleocapsid assembly and formation of cytoplasmic inclusions. $\mathrm{J}$ Virol. 1996 Feb;70(2):801-8.

García J, García-Barreno B, Vivo A, Melero JA. Cytoplasmic inclusions of respiratory syncytial virus-infected cells: formation of inclusion bodies in transfected cells that coexpress the nucleoprotein, the phosphoprotein, and the 22K protein. Virology. 1993 Jul;195(1):243-7

García O, Martín M, Dopazo J, Arbiza J, Frabasile S, Russi J, Hortal M, Perez-Breña P, Martínez I, García-Barreno B, et al. Evolutionary pattern of human respiratory syncytial virus (subgroup A): cocirculating lineages and correlation of genetic and antigenic changes in the G glycoprotein. J Virol. 1994 Sep;68(9):5448-59.

Ghildyal R, Mills J, Murray M, Vardaxis N, Meanger J. Respiratory syncytial virus matrix protein associates with nucleocapsids in infected cells. J Gen Virol. 2002 Apr; 83(Pt 4):753-7. 
Gilca R, De Serres G, Tremblay M, Vachon ML, Leblanc E, Boivin G, et al . Distribution and clinical impact of human respiratory syncytial virus genotypes in hospitalized children over 2 winter seasons. J Infect Dis. 2006 Jan 1;193(1):54-8.

Glezen WP, Paredes A, Allison JE, Taber LH, Frank AL. Risk of respiratory syncytial virus infection for infants from low-income families in relationship to age, sex, ethnic group, and maternal antibody level. J Pediatr. 1981 May;98(5):708-15.

Glezen, WP, Taber, LH, Frank, AL, Kasel, JA. Risk of primary infection and reinfection with respiratory syncytial virus. Am J Dis Child 1986; 140:543.

Greenberg HB, Piedra PA. Immunization against viral respiratory disease: a review. Pediatr Infect Dis J. 2004 Nov;23(11 Suppl):S254-61.

Groothuis JR. The role of RSV neutralizing antibodies in the treatment and prevention of respiratory syncytial virus infection in high-risk children. Antiviral Res. 1994 Jan; 23(1):1-10.

Hall CB, Douglas RG Jr, Geiman JM, Messner MK. Nosocomial respiratory syncytial virus infections. N Engl J Med. 1975 Dec 25;293(26):1343-6.

Hall, CB, Hall, WJ, Speers, DM. Clinical and physiological manifestations of bronchiolitis and pneumonia. Outcome of respiratory syncytial virus. Am J Dis Child. $1979 ; 133: 798$.

Hall CB, Douglas RG Jr, Schnabel KC, Geiman JM. Infectivity of respiratory syncytial virus by various routes of inoculation. Infect Immun. 1981 Sep;33(3):779-83.

Hall CB, Walsh EE, Schnabel KC, Long CE, McConnochie KM, Hildreth SW, Anderson LJ. Occurrence of groups A and B of respiratory syncytial virus over 15 years: associated epidemiologic and clinical characteristics in hospitalized and ambulatory children. J Infect Dis. 1990 Dec;162(6):1283-90.

Hall CB, Walsh EE, Long CE, Schnabel KC. Immunity to and frequency of reinfection with respiratory syncytial virus. J Infect Dis. 1991 Apr; 163(4):693-8.

Hall CB. Prospects for a respiratory syncytial virus vaccine. Science. 1994 Sep 2; 265(5177):1393-4.

Hall, CB, Long, CE, Schnabel, KC. Respiratory syncytial virus infections in previously healthy working adults. Clin Infect Dis. 2001; 33:792.

Halstead DC, Todd S, Fritch G. Evaluation of five methods for respiratory syncytial virus detection. J Clin Microbiol. 1990 May;28(5):1021-5. 
Hardy RW, Wertz GW. The product of the respiratory syncytial virus M2 gene ORF1 enhances readthrough of intergenic junctions during viral transcription. J Virol. 1998 Jan;72(1):520-6.

Henderson FW, Collier AM, Clyde WA Jr, Denny FW. Respiratory-syncytial-virus infections, reinfections and immunity. A prospective, longitudinal study in young children. N Engl J Med. 1979 Mar 8;300(10):530-4.

Hendry RM, Burns JC, Walsh EE, Graham BS, Wright PF, Hemming VG, et al. Strainspecific serum antibody responses in infants undergoing primary infection with respiratory syncytial virus. J Infect Dis. 1988 Apr;157(4):640-7.

Hendry RM, Pierik LT, McIntosh K. Prevalence of respiratory syncytial virus subgroups over six consecutive outbreaks: 1981-1987. J Infect Dis. 1989 Aug;160(2):185-90.

Henrickson KJ, Hoover S, Kehl KS, Hua W. National disease burden of respiratory viruses detected in children by polymerase chain reaction. Pediatr Infect Dis J. 2004 Jan;23(1 Suppl):S11-8.

Henrickson KJ, Hall CB. Diagnostic assays for respiratory syncytial virus disease. Pediatr Infect Dis J. 2007 Nov;26(11 Suppl):S36-40.

Hierholzer JC, Castells E, Banks GG, Bryan JA, McEwen CT. Sensitivity of NCI-H292 human lung mucoepidermoid cells for respiratory and other human viruses. J Clin Microbiol. 1993 Jun;31(6):1504-10.

Hierholzer JC, Tannock GA, Hierholzer CM, Coombs RA, Kennett ML, Phillips PA, Gust ID. Subgrouping of respiratory syncytial virus strains from Australia and Papua New Guinea by biological and antigenic characteristics. Arch Virol. 1994;136(1-2): 133-47.

Holberg CJ, Wright AL, Martinez FD, Ray CG, Taussig LM, Lebowitz MD. Risk factors for respiratory syncytial virus-associated lower respiratory illnesses in the first year of life. Am J Epidemiol. 1991 Jun 1;133(11):1135-51.

Hornsleth A, Klug B, Nir M, Johansen J, Hansen KS, Christensen LS, Larsen LB. Severity of respiratory syncytial virus disease related to type and genotype of virus and to cytokine values in nasopharyngeal secretions. Pediatr Infect Dis J. 1998 Dec;17(12): 1114-21.

Huang YT, Wertz GW. The genome of respiratory syncytial virus is a negative-stranded RNA that codes for at least seven mRNA species. J Virol. 1982 Jul;43(1):150-7.

Hughes JH. Physical and chemical methods for enhancing rapid detection of viruses and other agents. Clin Microbiol Rev. 1993 Apr;6(2):150-75. 
Imaz MS, Sequeira MD, Videla C, Veronessi I, Cociglio R, Zerbini E, Carballal G. Clinical and epidemiologic characteristics of respiratory syncytial virus subgroups $\mathrm{A}$ and B infections in Santa Fe, Argentina. J Med Virol. 2000 May;61(1):76-80.

Johnson PR, Spriggs MK, Olmsted RA, Collins PL. The G glycoprotein of human respiratory syncytial viruses of subgroups $A$ and $B$ : extensive sequence divergence between antigenically related proteins. Proc Natl Acad Sci U S A. 1987 Aug;84(16): $5625-9$.

Karron RA, Buonagurio DA, Georgiu AF, Whitehead SS, Adamus JE, Sidhu MS, et al. Respiratory syncytial virus (RSV) $\mathrm{SH}$ and G proteins are not essential for viral replication in vitro: clinical evaluation and molecular characterization of a coldpassaged, attenuated RSV subgroup B mutant. Proc Natl Acad Sci U S A. 1997 Dec 9;94(25):13961-6.

Kellogg JA. Culture vs direct antigen assays for detection of microbial pathogens from lower respiratory tract specimens suspected of containing the respiratory syncytial virus. Arch Pathol Lab Med. 1991 May;115(5):451-8.

Kneyber MC, Moll HA, de Groot R. Treatment and prevention of respiratory syncytial virus infection. Eur J Pediatr. 2000 Jun;159(6):399-411.

Kuroiwa Y, Nagai K, Okita L, Yui I, Kase T, Tsutsumi H, et al. A phylogenetic study of human respiratory syncytial viruses group A and B strains isolated in two cities in Japan from 1980-2002. J Med Virol. 2005; 76:241-247.

Lenard J. Negative-strand virus M and retrovirus MA proteins: all in a family? Virology. 1996 Feb 15;216(2):289-98.

Levine S, Klaiber-Franco R, Paradiso PR. Demonstration that glycoprotein G is the attachment protein of respiratory syncytial virus. J Gen Virol. 1987 Sep;68 ( Pt 9): 2521-4.

Lichtenstein DL, Roberts SR, Wertz GW, Ball LA. Definition and functional analysis of the signal/anchor domain of the human respiratory syncytial virus glycoprotein G. J Gen Virol. 1996 Jan;77 ( Pt 1):109-18.

Low KW, Tan T, Ng K, Tan BH, Sugrue RJ. The RSV F and G glycoproteins interact to form a complex on the surface of infected cells. Biochem Biophys Res Commun. 2008 Feb 8;366(2):308-13.

Maggon K, Barik S. New drugs and treatment for respiratory syncytial virus. Rev Med Virol. 2004;14:149-68. 
Martínez I, Valdés O, Delfraro A, Arbiza J, Russi J, Melero JA. Evolutionary pattern of the $\mathrm{G}$ glycoprotein of human respiratory syncytial viruses from antigenic group $\mathrm{B}$ : the use of alternative termination codons and lineage diversification. J Gen Virol. 1999 Jan; 80 ( Pt 1):125-30.

Mason SW, Lawetz C, Gaudette Y, Dô F, Scouten E, Lagacé L, Simoneau B, Liuzzi M. Polyadenylation-dependent screening assay for respiratory syncytial virus RNA transcriptase activity and identification of an inhibitor. Nucleic Acids Res. 2004 Sep 8;32(16):4758-67.

Mazzulli T, Peret TC, McGeer A, Cann D, MacDonald KS, Chua R, Erdman DD, Anderson LJ. Molecular characterization of a nosocomial outbreak of human respiratory syncytial virus on an adult leukemia/lymphoma ward. J Infect Dis. 1999 Nov;180(5): 1686-9.

Melero JA, García-Barreno B, Martínez I, Pringle CR, Cane PA. Antigenic structure, evolution and immunobiology of human respiratory syncytial virus attachment $(\mathrm{G})$ protein. J Gen Virol. 1997 Oct;78 ( Pt 10):2411-8.

Miyao CR, Gilio AE, Vieira S, Hein N, Pahl MM, Betta SL,et al. Viral infections in hospitalized children affected by acute lower respiratory tract disease. J Pediatr. 1999 Sep-Oct;75(5):334-44.

Morris JA, Blount RE Jr, Savage RE. Recovery of cytopathogenic agent from chimpanzees with coryza. Proc Soc Exp Biol Med. 1956 Jul;92(3):544-9.

Moura FE, Borges LC, Portes SA, Ramos EA, Siqueira MM. Respiratory syncytial virus infections during an epidemic period in Salvador, Brazil. Viral antigenic group analysis and description of clinical and epidemiological aspects. Mem Inst Oswaldo Cruz. 2003 Sep;98(6):739-43.

Moura FE, Nunes IF, Silva GB Jr, Siqueira MM. Respiratory syncytial virus infections in northeastern Brazil: seasonal trends and general aspects. Am J Trop Med Hyg. 2006 Jan;74(1):165-7.

Mufson MA, Orvell C, Rafnar B, Norrby E. Two distinct subtypes of human respiratory syncytial virus. J Gen Virol. 1985 Oct;66 ( Pt 10):2111-24.

Nagai K, Kamasaki H, Kuroiwa Y, Okita L, Tsutsumi H. Nosocomial outbreak of respiratory syncytial virus subgroup B variants with the 60 nucleotides-duplicated $G$ protein gene. J Med Virol. 2004; 74:161-165.

Nascimento CA, Souza TS, de Moraes CT, Vedovello D, Durigon EL, Botosso VF, et al. One-step reverse transcriptase polymerase chain reaction for the diagnosis of respiratory syncytial virus in children. J Virol Methods. 2007 Dec 7. 
Nascimento JP, Siqueira MM, Sutmoller F, Krawczuk MM, de Farias V, Ferreira V, Rodrigues MJ. Longitudinal study of acute respiratory diseases in Rio de Janeiro: occurrence of respiratory viruses during four consecutive years. Rev Inst Med Trop Sao Paulo. 1991 Jul-Aug;33(4):287-96.

Nokso-Koivisto J, Räty R, Blomqvist S, Kleemola M, Syrjänen R, Pitkäranta A, Kilpi T, Hovi T. Presence of specific viruses in the middle ear fluids and respiratory secretions of young children with acute otitis media. J Med Virol. 2004 Feb;72(2):241-8.

Ogra PL. Respiratory syncytial virus: the virus, the disease and the immune response. Paediatr Respir Rev. 2004;5 Suppl A:S119-26.

Ohm-Smith MJ, Nassos PS, Haller BL. Evaluation of the Binax NOW, BD Directigen, and BD Directigen EZ assays for detection of respiratory syncytial virus. J Clin Microbiol. 2004 Jul;42(7):2996-9.

Ong GM, Wyatt DE, O'Neill HJ, McCaughey C, Coyle PV. A comparison of nested polymerase chain reaction and immunofluorescence for the diagnosis of respiratory infections in children with bronchiolitis, and the implications for a cohorting strategy. $\mathrm{J}$ Hosp Infect. 2001 Oct;49(2):122-8.

Openshaw PJ, Culley FJ, Olszewska W. Immunopathogenesis of vaccine-enhanced RSV disease. Vaccine. 2001;20:S27-31.

Osur SL. Viral respiratory infections in association with asthma and sinusitis: a review. Ann Allergy Asthma Immunol. 2002 Dec; 89(6):553-60.

Ottolini MG, Hemming VG. Prevention and treatment recommendations for respiratory syncytial virus infection. Background and clinical experience 40 years after discovery. Drugs. 1997 Dec; 54(6):867-84.

Parveen S, Broor S, Kapoor SK, Fowler K, Sullender WM. Genetic diversity among respiratory syncytial viruses that have caused repeated infections in children from rural India. J Med Virol. 2006 May;78(5):659-65.

Peret TC, Hall CB, Schnabel KC, Golub JA, Anderson LJ. Circulation patterns of genetically distinct group $\mathrm{A}$ and $\mathrm{B}$ strains of human respiratory syncytial virus in a community. J Gen Virol. 1998 Sep;79 ( Pt 9):2221-9.

Peret TC, Hall CB, Hammond GW, Piedra PA, Storch GA, Anderson LJ, et al. Circulation patterns of group A and B human respiratory syncytial virus genotypes in 5 communities in North America. J Infect Dis. 2000 Jun;181(6):1891-6.

Perini AP, Barbosa ML, Botosso VF, de Moraes CT, Stewien KE, Durigon EL, et al. Comparison of HeLa-I, HEp-2 and NCI-H292 cell lines for the isolation of human respiratory syncytial virus (HRSV). J Virol Methods. 2007 Dec;146(1-2):368-71. 
Polack FP, Teng MN, Collins PL, Prince GA, Exner M, Karron RA, et al. A role for immune complexes in enhanced respiratory syncytial virus disease. J Exp Med. 2002 Sep 16;196(6):859-65.

Prince GA. An update on respiratory syncytial virus antiviral agents. Expert Opin Investig Drugs. 2001 Feb;10(2):297-308.

Reese PE, Marchette NJ. Respiratory syncytial virus infection and prevalence of subgroups A and B in Hawaii. J Clin Microbiol. 1991 Nov;29(11):2614-5.

Rixon HW, Brown G, Aitken J, McDonald T, Graham S, Sugrue RJ. The small hydrophobic $(\mathrm{SH})$ protein accumulates within lipid-raft structures of the Golgi complex during respiratory syncytial virus infection. J Gen Virol. 2004 May;85(Pt 5):1153-65.

Rovida F, Percivalle E, Zavattoni M, Torsellini M, Sarasini A, Gerna G. Monoclonal antibodies versus reverse transcription-PCR for detection of respiratory viruses in a patient population with respiratory tract infections admitted to hospital. J Med Virol. 2005 Feb;75(2):336-47.

Ruuskanen O, Ogra PL. Respiratory syncytial virus. Curr Probl Pediatr. 1993 Feb;23(2): 50-79.

Sander DM. The Big Picture Book of Viruses [homepage na internet]. Los Angeles: Tulane University New Orleans; c1995-2007 [acesso em 2008 Jan 07]. Paramyxoviridae [aproximadamente 3 telas]. Disponível em: http://www.tulane.edu/ dmsander/Big_Virology/BVHomePage.html

Sanz MC, Kew OM, Anderson LJ. Genetic heterogeneity of the attachment glycoprotein G among group A respiratory syncytial viruses. Virus Res. 1994 Sep;33(3):203-17.

Sarkkinen HK, Halonen PE, Arstila PP, Salmi AA. Detection of respiratory syncytial, parainfluenza type 2, and adenovirus antigens by radioimmunoassay and enzyme immunoassay on nasopharyngeal specimens from children with acute respiratory disease. J Clin Microbiol. 1981 Feb;13(2):258-65.

Sato MR, Saito T, Sakai Y, Sano M, Nishikawa A, Suzuki H, et al. Suzuki. Molecular epidemiology of respiratory syncytial virus infections among children with acute respiratory symptoms in a community over three seasons. J Clin Microbiol. 2005; 43:36-40.

Scott PD, Ochola R, Ngama M, Okiro EA, Nokes DJ, Medley GF, Cane PA. Molecular epidemiology of respiratory syncytial virus in Kilifi district, Kenya. J Med Virol. 2004 Oct;74(2):344-54. 
Shay DK, Holman RC, Newman RD, Liu LL, Stout JW, Anderson LJ. Bronchiolitisassociated hospitalizations among US children, 1980-1996. JAMA. 1999 Oct 20;282(15):1440-6.

Serafino RL, Gurgel RQ, Dove W, Hart CA, Cuevas LE. Respiratory syncytial virus and metapneumovirus in children over two seasons with a high incidence of respiratory infections in Brazil. Ann Trop Paediatr. 2004 Sep;24(3):213-7.

Silvestri M, Sabatini F, Defilippi AC, Rossi GA. The wheezy infant -- immunological and molecular considerations. Paediatr Respir Rev. 2004;5 Suppl A:S81-7.

Simoes EA, Carbonell-Estrany X. Impact of severe disease caused by respiratory syncytial virus in children living in developed countries. Pediatr Infect Dis J. 2003 Feb; 22(2 Suppl):S13-8; discussion S18-20.

Siqueira MM, Nascimento JP, Anderson LJ. Antigenic characterization of respiratory syncytial virus group A and B isolates in Rio de Janeiro, Brazil. J Clin Microbiol. 1991 Mar; 29(3):557-9.

Struck A, Forster J, Ihorst G, Werchau H, König W, König B. Respiratory syncytial virus: G gene genotype and disease severity. Pediatr Infect Dis J. 2004 Nov; 23(11): 1000-2.

Sullender WM, Mufson MA, Anderson LJ, Wertz GW. Genetic diversity of the attachment protein of subgroup B respiratory syncytial viruses. J Virol. 1991 Oct; 65(10):5425-34.

Sullender WM, Sun L, Anderson LJ. Analysis of respiratory syncytial virus genetic variability with amplified cDNAs. J Clin Microbiol. 1993 May; 31(5):1224-31.

Sullender WM, Mufson MA, Prince GA, Anderson LJ, Wertz GW. Antigenic and genetic diversity among the attachment proteins of group A respiratory syncytial viruses that have caused repeat infections in children. J Infect Dis. 1998 Oct; 178(4):925-32.

Sullender WM. Respiratory syncytial virus genetic and antigenic diversity. Clin Microbiol Rev. 2000 Jan;13(1):1-15.

Sutmöller F, Ferro ZP, Asensi MD, Ferreira V, Mazzei IS, Cunha BL. Etiology of acute respiratory tract infections among children in a combined community and hospital study in Rio de Janeiro. Clin Infect Dis. 1995 Apr;20(4):854-60.

Tang RS, Nguyen N, Cheng X, Jin H. Requirement of cysteines and length of the human respiratory syncytial virus M2-1 protein for protein function and virus viability. $\mathrm{J}$ Virol. 2001 Dec;75(23):11328-35. 
Taylor CE, Morrow S, Scott M, Young B, Toms GL. Comparative virulence of respiratory syncytial virus subgroups A and B. Lancet. 1989 Apr 8;1(8641):777-8.

Techaarpornkul S, Barretto N, Peeples ME. Functional analysis of recombinant respiratory syncytial virus deletion mutants lacking the small hydrophobic and/or attachment glycoprotein gene. J Virol. 2001 Aug;75(15):6825-34.

Teng MN, Whitehead SS, Collins PL. Contribution of the respiratory syncytial virus G glycoprotein and its secreted and membrane-bound forms to virus replication in vitro and in vivo. Virology. 2001 Oct 25;289(2):283-96.

Thomazelli LM. Vigilância epidemiológica de vírus respiratórios humanos em amostras clínicas pela técnica de GeneScan-RT-PCR [dissertação]. Instituto de Ciências Biomédicas. São Paulo: Universidade de São Paulo; 2004.

Thomazelli LM, Vieira S, Leal AL, Sousa TS, Oliveira DB, Golono MA, et al. Surveillance of eight respiratory viruses in clinical samples of pediatric patients in southeast Brazil. J Pediatr. 2007 Sep-Oct;83(5):422-8.

Tran TL, Castagné N, Bhella D, Varela PF, Bernard J, Chilmonczyk S, et al. The nine C-terminal amino acids of the respiratory syncytial virus protein $\mathrm{P}$ are necessary and sufficient for binding to ribonucleoprotein complexes in which six ribonucleotides are contacted per N protein protomer. J Gen Virol. 2007 Jan;88(Pt 1):196-206.

Trento A, Galiano M, Videla C, Carballal G, García-Barreno B, Melero JA, Palomo C. Major changes in the $\mathrm{G}$ protein of human respiratory syncytial virus isolates introduced by a duplication of 60 nucleotides. J Gen Virol. 2003 Nov;84(Pt 11):3115-20.

Tristam DA, Welliver RC. Respiratory syncytial virus. In: Diagnostic. Procedure for viral, rickettsial and chlamydial infections. 7ed. Washington: American Public Health Association; 1996.

Tsuchiya LR, Costa LM, Raboni SM, Nogueira MB, Pereira LA, Rotta I, Takahashi GR, Coelho M, Siqueira MM. Viral respiratory infection in Curitiba, Southern Brazil. J Infect. 2005 Dec;51(5):401-7.

Van den Hoogen BG, de Jong JC, Groen J, Kuiken T, de Groot R, Fouchier RA, Osterhaus AD. A newly discovered human pneumovirus isolated from young children with respiratory tract disease. Nat Med. 2001 Jun;7(6):719-24.

Van Regenmortel MHV, Fauquet CM, Bishop DHL, Carstens EB, Estes MK, Lemon SM, et al, editors. Virus Taxonomy. Seventh Report of the International Committee on Taxonomy of Viruses. New York: Academic Press; 2000. p. 1162. 
Van Woensel JB, Kimpen JL, Brand PL. Respiratory tract infections caused by respiratory syncytial virus in children. Diagnosis and treatment. Minerva Pediatr. 2001 Apr;53(2):99-106.

Venkatesh MP, Weisman LE. Prevention and treatment of respiratory syncytial virus infection in infants: an update. Expert Rev Vaccines. 2006 Apr;5(2):261-8.

Venter M, Madhi SA, Tiemessen CT, Schoub BD. Genetic diversity and molecular epidemiology of respiratory syncytial virus over four consecutive seasons in South Africa: identification of new subgroup A and B genotypes. J Gen Virol. 2001 Sep;82(Pt 9):2117-24.

Vieira SE, Stewien KE, Queiroz DA, Durigon EL, Török TJ, Anderson LJ, et al. Clinical patterns and seasonal trends in respiratory syncytial virus hospitalizations in São Paulo, Brazil. Rev Inst Med Trop Sao Paulo. 2001 May-Jun;43(3):125-31.

Vieira SE, Gilio AE, Miyao CR, Pahl MMC, Lotufo JPB, Hein N, et al. Infecção nosocomial pelo vírus respiratório sincicial em enfermaria de pediatria. Pediatria (São Paulo). 2002;24(1/2):17-24.

Walsh EE, Hruska J. Monoclonal antibodies to respiratory syncytial virus proteins: identification of the fusion protein. J Virol. 1983 Jul;47(1):171-7.

Walsh, EE, Falsey, AR, Hennessey, PA. Respiratory syncytial and other virus infections in persons with chronic cardiopulmonary disease. Am J Respir Crit Care Med 1999; 160:791.

Waris M. Detection and antigenic variation of respiratory syncytial virus [ $\mathrm{PhD}$. thesis]. University of Turkey; 1992. AII. 79:86.

Weber MW, Mulholland EK, Greenwood BM. Respiratory syncytial virus infection in tropical and developing countries. Trop Med Int Health. 1998 Apr;3(4):268-80.

Welliver RC. Respiratory syncytial virus and other respiratory viruses. Pediatr Infect Dis J. 2003 Feb;22(2 Suppl):S6-10.

Wertz GW, Collins PL, Huang Y, Gruber C, Levine S, Ball LA. Nucleotide sequence of the $\mathrm{G}$ protein gene of human respiratory syncytial virus reveals an unusual type of viral membrane protein. Proc Natl Acad Sci U S A. 1985 Jun;82(12):4075-9.

World Health Organization. The world health report 2004 - changing history. Geneva, Switzerland: World Health Organization; 2004.

Yu Q, Hardy RW, Wertz GW. Functional cDNA clones of the human respiratory syncytial (RS) virus $\mathrm{N}, \mathrm{P}$, and L proteins support replication of RS virus genomic RNA analogs and define minimal trans-acting requirements for RNA replication. J Virol. 1995 Apr; 69(4):2412-9. 
Yusuf S, Piedimonte G, Auais A, Demmler G, Krishnan S, Van Caeseele P, Singleton R, Broor S, Parveen S, Avendano L, Parra J, Chavez-Bueno S, Murguía De Sierra T, Simoes EA, Shaha S, Welliver R. The relationship of meteorological conditions to the epidemic activity of respiratory syncytial virus. Epidemiol Infect. 2007 Oct;135(7): 1077-90.

Zhang W, Yang H, Kong X, Mohapatra S, San Juan-Vergara H, Mohapatra SS, et al. Inhibition of respiratory syncytial virus infection with intranasal siRNA nanoparticles targeting the viral NS1 gene. Nat Med. 2005 Jan;11(1):56-62.

Zheng H, Peret TC, Randolph VB, Crowley JC, Anderson LJ. Strain-specific reverse transcriptase PCR assay: means to distinguish candidate vaccine from wild-type strains of respiratory syncytial virus. J Clin Microbiol. 1996 Feb;34(2):334-7.

Zlateva KT, Lemey P, Moës E, Vandamme AM, Van Ranst M. Molecular evolution and circulation patterns of human respiratory syncytial virus subgroup A: positively selected sites in the attachment G glycoprotein. J. Virol. 2004; 78: 4675-83.

Zlateva KT, Lemey P, Moës E, Vandamme AM, Van Ranst M. Genetic variability and molecular evolution of the human respiratory syncytial virus subgroup $B$ attachment $G$ protein. J Virol. 2005 Jul; 79(14):9157-67. 


\title{
ANEXO 1: Termo de consentimento pós-informado
}

\author{
Universidade de São Paulo \\ Instituto de Ciências Biomédicas
}

\section{TERMO DE CONSENTIMENTO LIVRE E ESCLARECIDO}

(menores de 18 anos)

\section{ESTUDO:}

Seu filho está sendo convidado a participar do projeto de pesquisa acima citado. O documento abaixo contém todas as informações necessárias sobre a pesquisa que estamos fazendo, então leia atentamente e caso tenha dúvidas, vou esclarecê-las (se não souber ler, fique tranqüilo(a) que leio para você). Se concordar, o documento será assinado e só então daremos início à pesquisa. Sua colaboração neste estudo será de muita importância para nós, mas se desistir a qualquer momento, isso não causará nenhum prejuizo a você, nem ao seu (sua) filho(a).

$\mathrm{Eu}$

RG , abaixo assinado(a), concordo de livre e espontânea vontade que meu(minha) filho(a) nascido(a) em /__ seja voluntário do estudo “...”, esclareço que obtive todas informações necessárias e fui esclarecido(a) de todas as dúvidas apresentadas.

Estou ciente que:

I) O estudo se faz necessário para que possam descobrir as possíveis causas da doença denominada "Doenças Respiratórias" (explicar o que significa os termos científicos).

II) Serão feitas duas coletas de aspirado de nasofaringe do(a) meu(minha) filho(a);

III) Essas coletas serão feitas apenas para este estudo e em nada influenciará no tratamento de meu (minha) filho(a); não vai curá-lo (a); mas não causará nenhum problema;

IV) A participação neste projeto não tem objetivo de se submeter a um tratamento terapêutico e será sem custo algum para mim;

V) Tenho a liberdade de desistir ou interromper a colaboração neste estudo no momento em que desejar, sem necessidade de qualquer explicação;

VI) A desistência não causará nenhum prejuízo a mim, nem ao(a) meu (minha) filho(a), e sem que venha interferir no atendimento ou tratamento médico; 
VII) Os resultados obtidos durante este ensaio serão mantidos em sigilo, mas concordo que sejam divulgados em publicações científicas, desde que nem o meu nome nem o de meu filho sejam mencionados;

VIII) Caso eu desejar, poderei tomar conhecimento dos resultados ao final desta pesquisa

( ) Desejo conhecer os resultados desta pesquisa.

( ) Não desejo conhecer os resultados desta pesquisa.

São Paulo, de de 2004

( ) Paciente / ( ) Responsável

Testemunha 1:

Nome / RG / Telefone

Testemunha 2 :

Nome / RG / Telefone

Responsável pelo Projeto:

Dr. RESPONSÁVEL 
ANEXO 2: Número de acesso ao GenBank das amostras utilizadas para a comparação e realização das Análises Filogenéticas do HRSV.

\begin{tabular}{|c|c|c|c|}
\hline Amostra & Genótipo & Nr. Acesso & Referência \\
\hline \multicolumn{4}{|l|}{ Tipo A } \\
\hline A2 & Protótipo & X03149 & SATAKE et al., 1985 \\
\hline LONG & Protótipo & M17212 & JOHNSON et al., 1987 \\
\hline CH34 & GA1 & AF065257 & PERET et al., 1998 \\
\hline AL19471_5 & GA1 & AF233902 & PERET et al., 2000 \\
\hline NY108 & GA1 & AF233917 & PERET et al., 2000 \\
\hline MO48 & GA1 & AF233914 & PERET et al., 2000 \\
\hline $\mathrm{CH} 57$ & GA2 & AF065258 & PERET et al., 1998 \\
\hline $\mathrm{CH} 28$ & GA2 & AF065256 & PERET et al., 1998 \\
\hline AL19376_1 & GA2 & AF233900 & PERET et al., 2000 \\
\hline MO55 & GA2 & AF233915 & PERET et al., 2000 \\
\hline TX69564 & GA2 & AF233923 & PERET et al., 2000 \\
\hline CN2395 & GA3 & AF233905 & PERET et al., 2000 \\
\hline MO13 & GA3 & AF233911 & PERET et al., 2000 \\
\hline TX68481 & GA3 & AF233920 & PERET et al., 2000 \\
\hline MO16 & GA3 & AF233913 & PERET et al., 2000 \\
\hline TX68532 & GA3 & AF233921 & PERET et al., 2000 \\
\hline CH09 & GA4 & AF065254 & PERET et al., 1998 \\
\hline AL19556_3 & GA5 & AF233903 & PERET et al., 2000 \\
\hline CN3114 & GA5 & AF233908 & PERET et al., 2000 \\
\hline MO15 & GA5 & AF233912 & PERET et al., 2000 \\
\hline CN2708 & GA5 & AF233906 & PERET et al., 2000 \\
\hline TX69343 & GA5 & AF233922 & PERET et al., 2000 \\
\hline NY103 & GA5 & AF233916 & PERET et al., 2000 \\
\hline TX67951 & GA5 & AF233919 & PERET et al., 2000 \\
\hline MO01 & GA5 & AF233909 & PERET et al., 2000 \\
\hline AL19452_2 & GA6 & AF233901 & PERET et al., 2000 \\
\hline NY20 & GA6 & AF233918 & PERET et al., 2000 \\
\hline CN1973 & GA7 & AF233904 & PERET et al., 2000 \\
\hline CN2851 & GA7 & AF233907 & PERET et al., 2000 \\
\hline MO02 & GA7 & AF233910 & PERET et al., 2000 \\
\hline SA97D669 & SAA1 & AF348809 & VENTER et al., 2001 \\
\hline SA98D707 & SAA1 & AF348810 & VENTER et al., 2001 \\
\hline
\end{tabular}


Amostra

Genótipo

Nr. Acesso

Tipo B

SW8 60

CH18537

BE 1315902

BE 1237001

BE 4603

BE 62602

Ken 2903

BA 35404

BE 1461003

BE 1345703

BE 25704

BA 152604

QUE 7002

BA 49304

BA 52404

QUE 9902

BE 1267001

BE 92003

BE 1235802

BA 502103

BA 490903

BA 485203

BA 160704

BA 483003

BA 497403

BA 144102

BA 156502

BA 482503

BA 188902

BA 100402

BA 185602

BA 151802

BA 49502

NG 00603

NG 00403

BA 132699

BA 160602

BA 146102

BA 73302

BA 16702

BA 61902

BA 127102

BA 121402

BA 77002
Protótipo M55633

Protótipo M17213

B com inserção AY751117

B com inserção AY751118

B com inserção AY751110

B com inserção AY751115

B com inserção AY660681

B com inserção DQ227406

B com inserção AY751093

B com inserção AY751087

B com inserção AY751092

B com inserção DQ227408

B com inserção AY927406

B com inserção DQ227407

B com inserção DQ227396

B com inserção AY927409

B com inserção AY751086

B com inserção AY751085

B com inserção AY751084

B com inserção DQ227405

B com inserção DQ227404

B com inserção DQ227403

B com inserção DQ227397

B com inserção DQ227402

B com inserção DQ227392

B com inserção DQ227381

B com inserção DQ227385

B com inserção DQ227401

B com inserção DQ227388

B com inserção DQ227376

B com inserção DQ227387

B com inserção DQ227383

B com inserção DQ227370

$\mathrm{B}$ com inserção $\mathrm{AB} 175820$

$\mathrm{B}$ com inserção AB175819

B com inserção DQ227398

B com inserção DQ227386

B com inserção DQ227382

B com inserção DQ227374

B com inserção DQ227369

B com inserção DQ227372

B com inserção DQ227380

B com inserção DQ227379

B com inserção DQ227373
Referência

Sullender et al., 1990

Johnson et al., 1987

Zlateva et al., 2005

Zlateva et al., 2005

Zlateva et al., 2005

Zlateva et al., 2005

Scott et al., 2004

Trento et al., 2006

Zlateva et al., 2005

Zlateva et al., 2005

Zlateva et al., 2005

Trento et al., 2006

Gilca et al., 2006

Trento et al., 2006

Trento et al., 2006

Gilca et al., 2006

Zlateva et al., 2005

Zlateva et al., 2005

Zlateva et al., 2005

Trento et al., 2006

Trento et al., 2006

Trento et al., 2006

Trento et al., 2006

Trento et al., 2006

Trento et al., 2006

Trento et al., 2006

Trento et al., 2006

Trento et al., 2006

Trento et al., 2006

Trento et al., 2006

Trento et al., 2006

Trento et al., 2006

Trento et al., 2006

Sato et al., 2005

Sato et al., 2005

Trento et al., 2006

Trento et al., 2006

Trento et al., 2006

Trento et al., 2006

Trento et al., 2006

Trento et al., 2006

Trento et al., 2006

Trento et al., 2006

Trento et al., 2006 


\begin{tabular}{|c|c|c|c|}
\hline BA 399799 & B com inserção & DQ227366 & Trento et al., 2006 \\
\hline BA 80299 & $\mathrm{~B}$ com inserção & DQ227363 & Trento et al., 2006 \\
\hline BE 1341799 & B com inserção & AY751131 & Zlateva et al., 2005 \\
\hline BE 1236901 & $\mathrm{~B}$ com inserção & AY751130 & Zlateva et al., 2005 \\
\hline BA 514003 & B com inserção & DQ227393 & Trento et al., 2006 \\
\hline BA 116102 & B com inserção & DQ227377 & Trento et al., 2006 \\
\hline BA 486203 & $\mathrm{~B}$ com inserção & DQ227391 & Trento et al., 2006 \\
\hline BA 482603 & $\mathrm{~B}$ com inserção & DQ227389 & Trento et al., 2006 \\
\hline NG 15303 & $\mathrm{~B}$ com inserção & $\mathrm{AB} 175821$ & Sato et al., 2005 \\
\hline BE 1234902 & B com inserção & AY751121 & Zlateva et al., 2005 \\
\hline BE 106603 & $\mathrm{~B}$ com inserção & AY751123 & Zlateva et al., 2005 \\
\hline QUE 10802 & B com inserção & AY927410 & Gilca et al., 2006 \\
\hline BE 30204 & $\mathrm{~B}$ com inserção & AY751124 & Zlateva et al., 2005 \\
\hline BE 1173201 & $\mathrm{~B}$ com inserção & AY751112 & Zlateva et al., 2005 \\
\hline BE 21003 & $\mathrm{~B}$ com inserção & AY751111 & Zlateva et al., 2005 \\
\hline BE 180203 & B com inserção & AY751109 & Zlateva et al., 2005 \\
\hline BE 1281703 & B com inserção & AY751091 & Zlateva et al., 2005 \\
\hline BE 78804 & B com inserção & AY751090 & Zlateva et al., 2005 \\
\hline BE 1297303 & B com inserção & AY751089 & Zlateva et al., 2005 \\
\hline BE 1305803 & $\mathrm{~B}$ com inserção & AY751088 & Zlateva et al., 2005 \\
\hline QUE 8503 & $\mathrm{~B}$ com inserção & AY927408 & Gilca et al., 2006 \\
\hline BA 656403 & B com inserção & DQ227394 & Trento et al., 2006 \\
\hline BA 120802 & B com inserção & DQ227378 & Trento et al., 2006 \\
\hline BA 144502 & B com inserção & DQ227399 & Trento et al., 2006 \\
\hline BA 16602 & B com inserção & DQ227368 & Trento et al., 2006 \\
\hline BA 50502 & B com inserção & DQ227371 & Trento et al., 2006 \\
\hline BA 16402 & B com inserção & DQ227367 & Trento et al., 2006 \\
\hline BE 1168301 & $\mathrm{~B}$ com inserção & AY751129 & Zlateva et al., 2005 \\
\hline BE 1170201 & B com inserção & AY751128 & Zlateva et al., 2005 \\
\hline BE 75802 & $\mathrm{~B}$ com inserção & AY751127 & Zlateva et al., 2005 \\
\hline BE 1153501 & B com inserção & AY751126 & Zlateva et al., 2005 \\
\hline BE 1244601 & B com inserção & AY751125 & Zlateva et al., 2005 \\
\hline BE 1239402 & B com inserção & AY751120 & Zlateva et al., 2005 \\
\hline BE 1252201 & B com inserção & AY751119 & Zlateva et al., 2005 \\
\hline BA 137099 & $\mathrm{~B}$ com inserção & DQ227364 & Trento et al., 2006 \\
\hline BA 156202 & B com inserção & DQ227384 & Trento et al., 2006 \\
\hline BA 393199 & $\mathrm{~B}$ com inserção & DQ227365 & Trento et al., 2006 \\
\hline BA 491503 & B com inserção & DQ227390 & Trento et al., 2006 \\
\hline BA 99802 & B com inserção & DQ227375 & Trento et al., 2006 \\
\hline BE 1150001 & B com inserção & AY751105 & Zlateva et al., 2005 \\
\hline BE 1160901 & B com inserção & AY751102 & Zlateva et al., 2005 \\
\hline BE 116202 & B com inserção & AY751104 & Zlateva et al., 2005 \\
\hline BE 1181301 & B com inserção & AY751100 & Zlateva et al., 2005 \\
\hline BE 119202 & $\mathrm{~B}$ com inserção & AY751095 & Zlateva et al., 2005 \\
\hline BE 1194901 & B com inserção & AY751097 & Zlateva et al., 2005 \\
\hline BE 1237901 & B com inserção & AY751106 & Zlateva et al., 2005 \\
\hline
\end{tabular}


BE 1239801 B com inserção AY751096

BE 1259501 B com inserção AY751107

BE $1259801 \quad \mathrm{~B}$ com inserção AY751108

BE 1265301 B com inserção AY751099

BE 158402 B com inserção AY751101

BE 161302 B com inserção AY751103

BE 1150801 B com inserção AY751116

BE 1215803 B com inserção AY751113
Zlateva et al., 2005

Zlateva et al., 2005

Zlateva et al., 2005

Zlateva et al., 2005

Zlateva et al., 2005

Zlateva et al., 2005

Zlateva et al., 2005

Zlateva et al., 2005 
ANEXO 3: Classificação das amostras de HRSV com inserção de 60 nucleotídeos, segundo Trento et al. (2006). De acordo com essa classificação, algumas amostras brasileiras permaneceram sem identificação.

\begin{tabular}{|c|c|}
\hline Amostra & Classificação \\
\hline Br42_01 & Sem classificação \\
\hline Br105_03 & Sem classificação \\
\hline Br140_03 & Sem classificação \\
\hline Br219_05 & Sem classificação \\
\hline Br301_05 & Sem classificação \\
\hline Br93_04 & BA II \\
\hline Br149_05 & BA IV \\
\hline Br154_05 & BA IV \\
\hline Br158_05 & BA IV \\
\hline Br178_05 & BA IV \\
\hline Br200_05 & BA IV \\
\hline Br205_05 & BA IV \\
\hline Br216_05 & BA IV \\
\hline Br217_05 & BA IV \\
\hline Br222_05 & BA IV \\
\hline Br233_05 & BA IV \\
\hline Br236_05 & BA IV \\
\hline Br237_05 & BA IV \\
\hline Br242_05 & BA IV \\
\hline Br252_05 & BA IV \\
\hline Br259_05 & BA IV \\
\hline Br271_05 & BA IV \\
\hline Br274_05 & BA IV \\
\hline Br290_05 & BA IV \\
\hline Br293_05 & BA IV \\
\hline Br305_05 & BA IV \\
\hline Br307_05 & BA IV \\
\hline Br319_05 & BA IV \\
\hline Br319_05 & BA IV \\
\hline Br332_05 & BA IV \\
\hline Br564_06 & BA IV \\
\hline Amostra & Classificação \\
\hline Br591_06 & BA IV \\
\hline Br609_06 & BA IV \\
\hline
\end{tabular}




\begin{tabular}{|l|l|}
\hline Br611_06 & BA IV \\
\hline Br618_06 & BA IV \\
\hline Br630_06 & BA IV \\
\hline Br636_06 & BA IV \\
\hline Br652_06 & BA IV \\
\hline Br655_06 & BA IV \\
\hline Br658_06 & BA IV \\
\hline Br660_06 & BA IV \\
\hline Br667_06 & BA IV \\
\hline Br671_06 & BA IV \\
\hline Br672_06 & BA IV \\
\hline Br676_06 & BA IV \\
\hline Br682_06 & BA IV \\
\hline Br691_06 & BA IV \\
\hline Br694_06 & BA IV \\
\hline Br1040_06 & BA IV \\
\hline Br1077_06 & BA IV \\
\hline Br1089_06 & BA IV \\
\hline Br1257_06 & BA IV \\
\hline Br1265_06 & BA IV \\
\hline Br1281_06 & BA IV \\
\hline Br1372_06 & BA IV \\
\hline Br1380_06 & BA IV \\
\hline
\end{tabular}


ANEXO 4: Alinhamento das seqüências parciais de aminoácidos da proteína G de HRSV dos anos de 2001 a 2006.

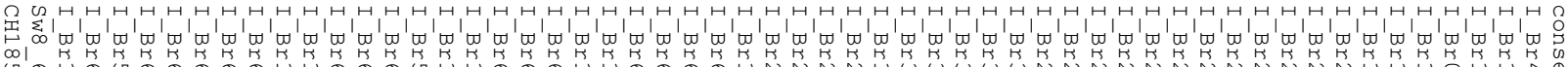

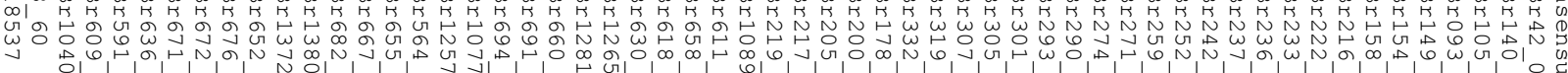

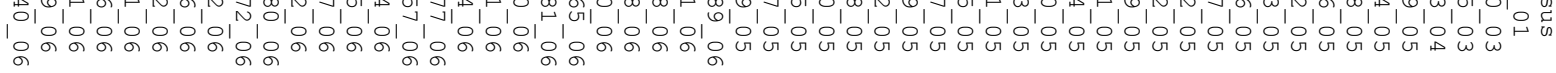

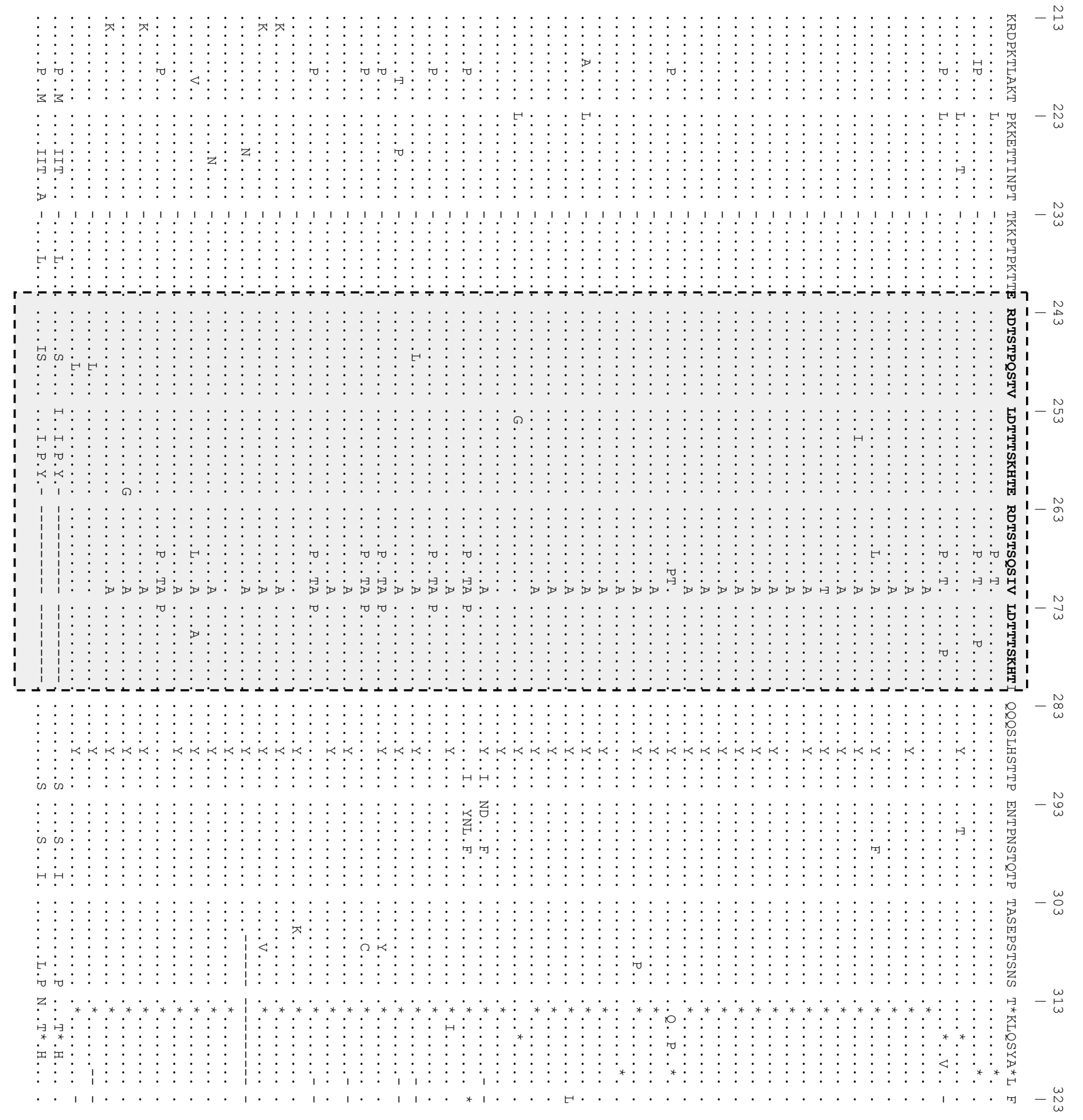


ANEXO 5: Alinhamento das seqüências parciais de nucleotídeos da proteína G de HRSV dos anos de 2001 a 2006.
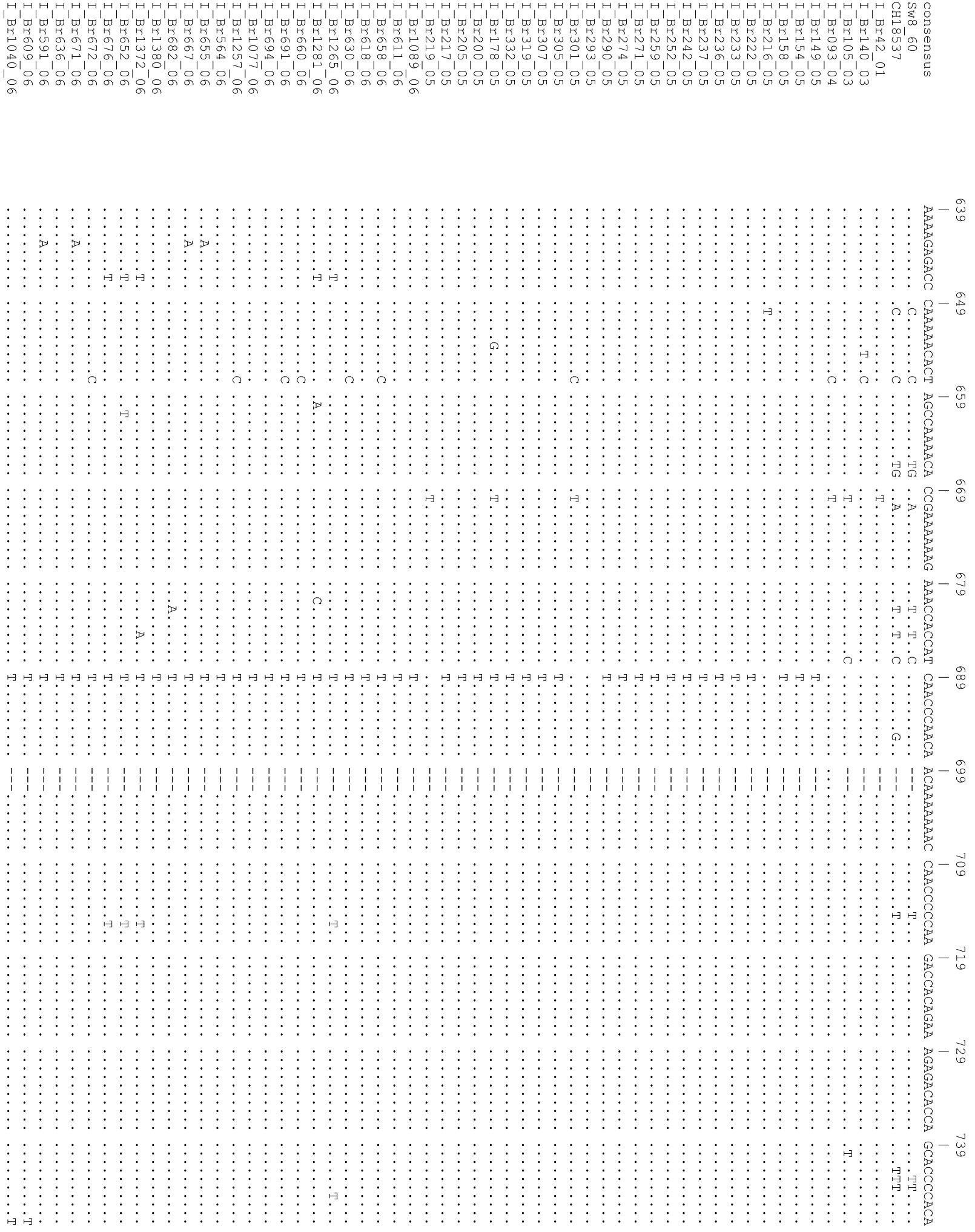


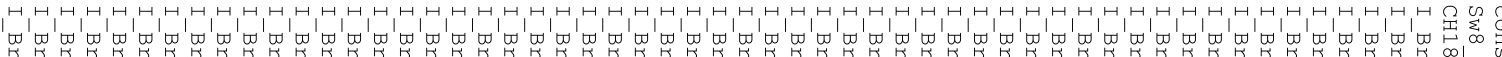

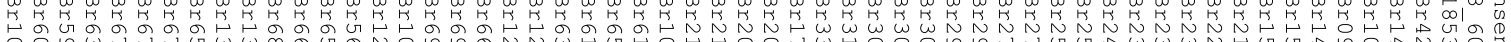

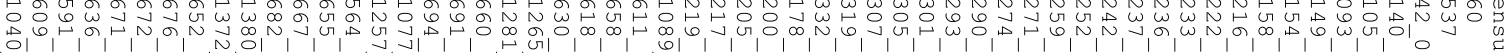

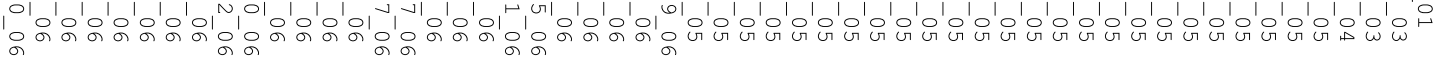

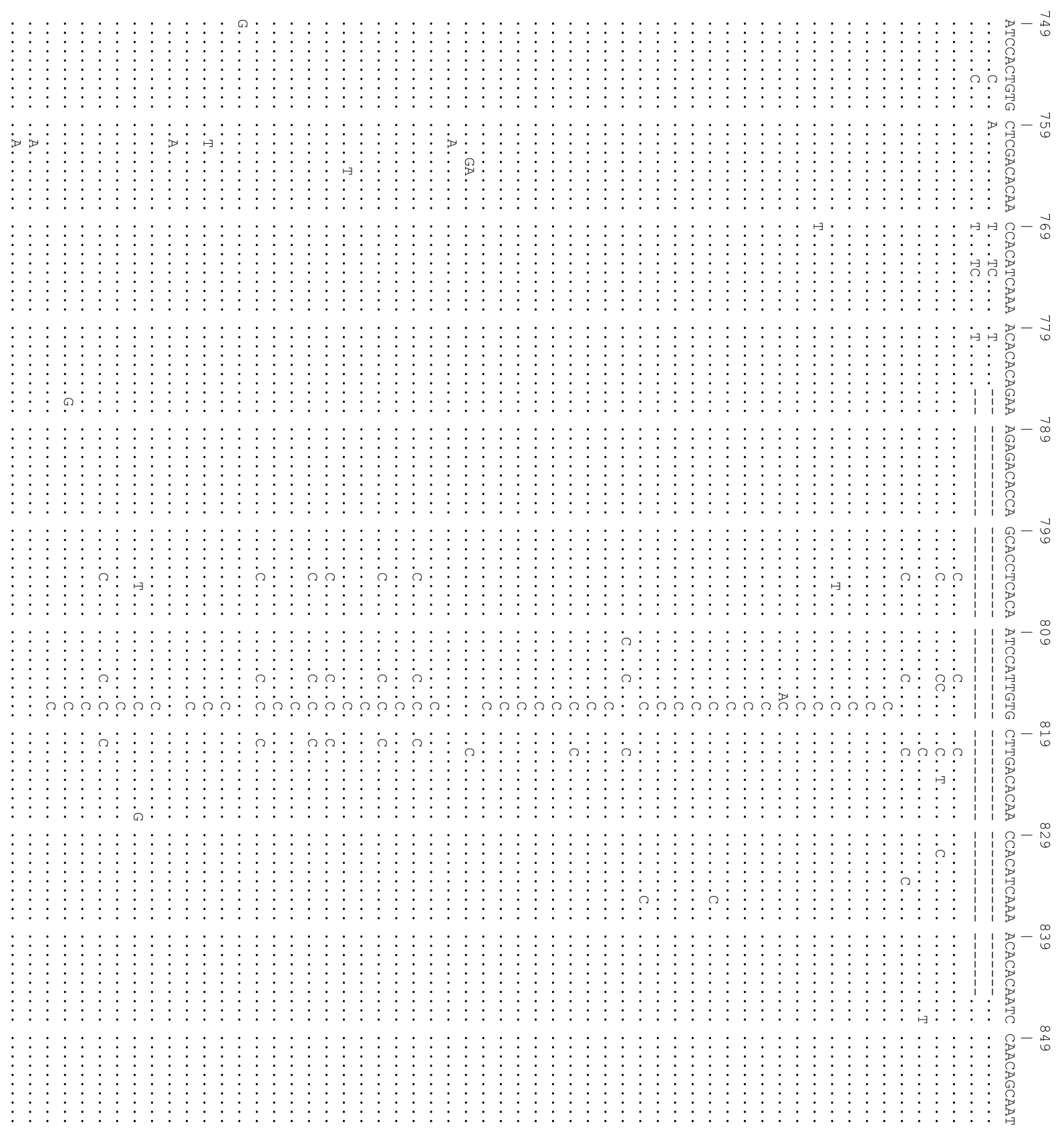


।

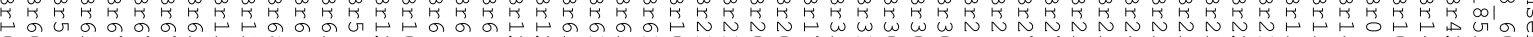

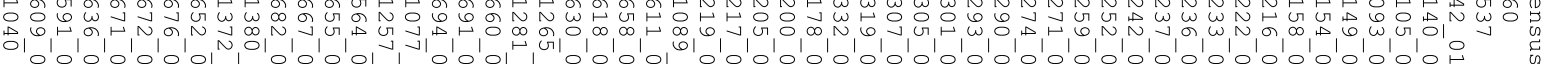
।

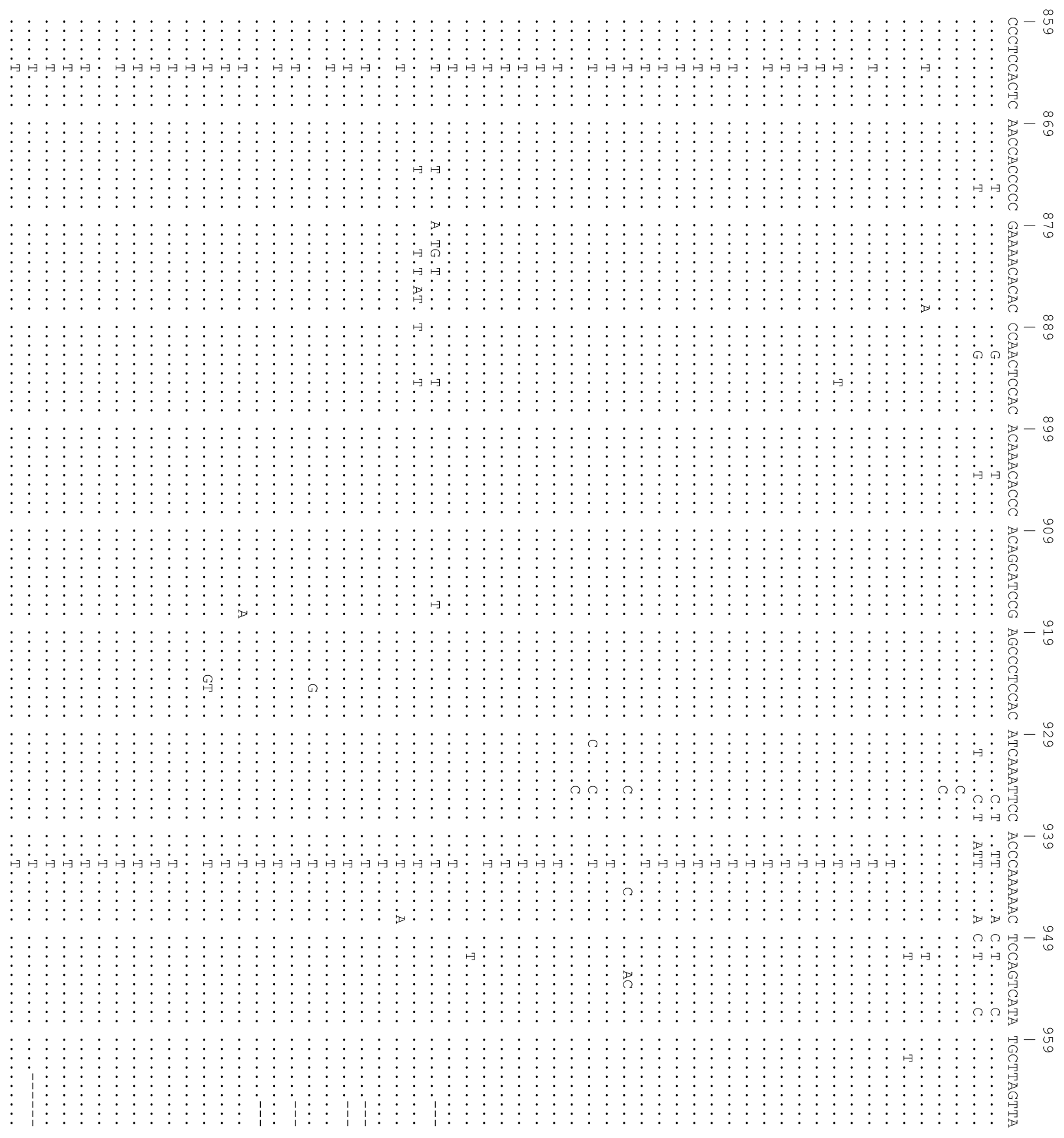

